\title{
Lazaroa
}

ISSN: 0210-9778

\section{Forest typology of broadleaf forests from Sierra Maestra, Eastern Cuba}

\author{
Orlando J. Reyes ${ }^{1}$
}

Received: 28 January 2015 / Accepted: 23 March 2016

\begin{abstract}
A phytosociological study of the forests from Sierra Maestra is conducted, following the methodology of the Zurich- Montpelier School. They are transformed into a forest typology using the standards of the Institute of AgroForestry Research. In general, 35 types and/or subtypes are presented. From this group, the most abundant ones belong to semi-deciduous microphyll forest, followed by those from mangroves and mountain rainforest, respectively. Silvicultural treatments are needed; among them, the protection forests are those found above $800 \mathrm{~m}$ asl and mangroves.
\end{abstract}

Keywords: Forests; forest typology; Sierra Maestra; Eastern Cuba.

\section{[es] Tipología forestal de los bosques latifolios de la Sierra Maestra, Cuba Oriental}

Resumen. Utilizando la metodología de la Escuela Zürich-Montpellier se realiza un estudio fitocenológico de los bosques de la Sierra Maestra, el cual es transformado en una Tipología Forestal usando los normas del Instituto de Investigaciones Agro-Forestales. En general, se presentan 35 tipos y/o subtipos, de los cuales los más abundantes pertenecen a los bosques semideciduos micrófilos, siguiéndole los manglares y la pluvisilva montana. Se precisan los tratamientos silvícolas, entre los cuales constituyen bosques de protección los que se encuentran por encima de los 800 $\mathrm{m}$ snm y los manglares.

Palabras clave: Bosques; Tipología forestal; Sierra Maestra; Cuba Oriental.

\section{Introduction}

Forests provide many goods and services to humanity, mainly related to the conservation of biodiversity, soil and water. In the current situation of climate change they also work as carbon sinks, so it is essential their conservation and sustainable use. The number of Cuban forest formations depends on the classification used: Bisse (1988) identified 16 forest formations located throughout the country; while Reyes (2011-2012) found 23, for Eastern Cuba (with six subtypes) and 11, for Sierrra Maestra, with four subtypes (Reyes, 2006). The forestry law in Cuba categorized Cuban forests as producers, for conservation and protective. The $46.1 \%$ of the Cuban forest heritage are protective areas, while the $32.3 \%$ are for timber production (Alvarez \& al.,
2012). This shows the significance the Cuban state gives to forests.

The Cuban forest area has increased significantly: from a $13.4 \%$ of degraded forests in 1959 (Russó Milhet, 2015), to a 26.2\% in 2009 (Alvarez \& al., 2012) and 28.6\% in 2014 (CITMA, 2014; Parada \& Torranzo, 2014) in relation to the surface of the Cuban archipelago.

While studying nature, it is important to recognize the set of ecological conditions (oecotope) that are expressed in the characteristics of the vegetation and its floristic composition. Forest typology is of great significance when the results of such interrelationship constitute in a particular type of forest. Therefore, it is considered as forest typology the study of forest communities in its relation to environmental conditions; since they establish the quality and productive potential of the forest stations (sites). Alvarez \& Varona

Eastern Center of Ecosystems and Biodiversity (BIOECO), Ministry of Science, Technology and Environment (CITMA), José A. Saco Nr. 601, esq. Barnada, Santiago de Cuba, Cuba. E mail joel@bioeco.cu 
(1988) considered as a forest site to all edaphic, climatic and biotic factors that determine the persistence and intensity of biomass production (gross primary productivity) of certain forest community, be it natural or created by man.

There are two basic methods for studying forest sites depending on the environmental situation: with emphasis on the oecotope (Kopp, 1965; Thomasius, 1965; Schwanecke, 1970) or prioritizing vegetation (Del Risco, 2000a, b; Del Risco \& Samek, 1984). The method that prioritizes the oecotope is recommended in areas where the vegetation has been destroyed, while the other is applied in stations where the existing vegetation expresses the potential of that oecotope. In this work, the second method is applied because it is conducted in developed vegetation, which, although it is often secondary, also expresses the environmental conditions, including ecosystem values, which contribute to forest typing and planning.

\section{Materials and Methods}

\section{Natural conditions of the study area}

Sierra Maestra (Figure 1) is a very complex area, geologically speaking. There, the Palaeocene-Eocene volcano-sedimentary rocks of the Cobre Group predominate, mainly andesites and tuffs (Mendez et al., 1994). Relatively large granites intrusives occur in isolated areas of the southern slope (around Potrerillo river, Pinar de las Canas, La Francia, Nima Nima, Juraguá-El Olimpo, etc). Likewise, the formations Maya River and Jaimanitas prevail in the coastal areas (Com. Cubano Húngara, 1976).

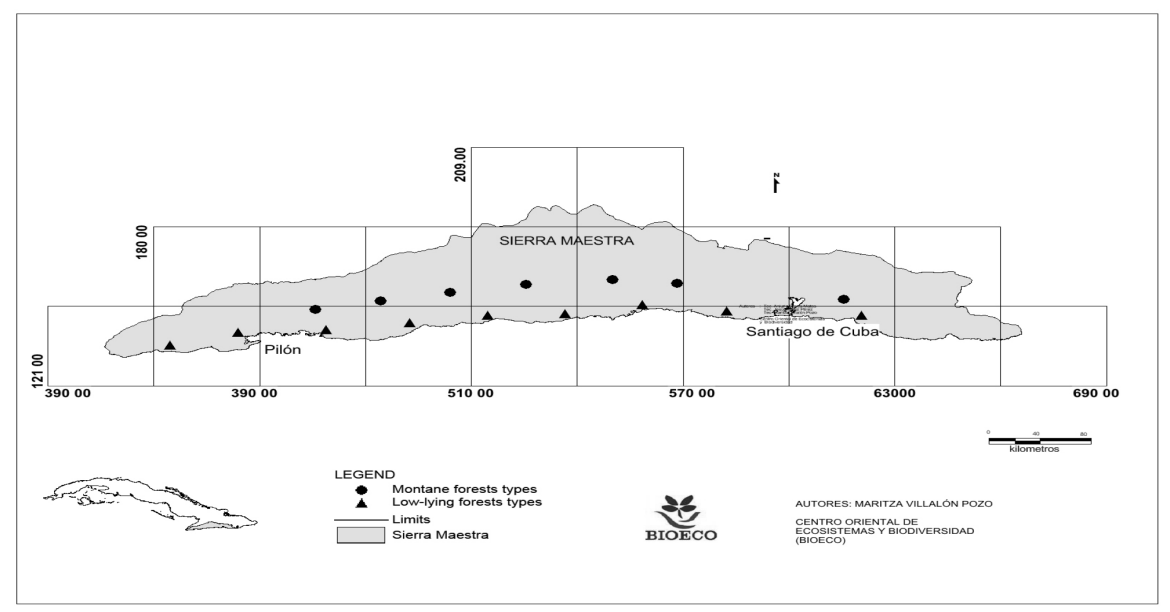

Figure 1. Main forests types in Sierra Maestra range (Cuba)

From $1500 \mathrm{~m}$ asl, the leached yellowish ferrallitic soil predominates. According to Renda (1989), the $\mathrm{pH}$ in the upper horizons is from acid to very acidic; it reaches values of 4.45 to 5.3 in water and 3.5 to 4.15 in $\mathrm{ClK}$. The sum of basic cations (Change Bases Capacity, CCB, S value) is very low, generally ranging between 1.44 and $5.02 \mathrm{cmol}(+) \cdot \mathrm{kg}^{-1}$. The cation exchange capacity (CIC, $\mathrm{T}$ value) varies from 2.5 to $18.75 \mathrm{cmol}(+) . \mathrm{kg}^{-1}$. There are very low content of calcium, magnesium and potassium. Beneath this soil, to about 600 $\mathrm{m}$ a.s.l, the soils are mainly leached red ferrallitic, from deep to very deep, and often derived from ferrallitic weathering crust in more or less stable places. They are from acids to highly acidic $\left(\mathrm{pH} \mathrm{H}_{2} \mathrm{O}\right.$ 4.0-5.5) and the $\mathrm{S}$ value is smaller than $7 \mathrm{cmol}(+) \cdot \mathrm{kg}^{-1}$ (Renda, 1989; Renda \& al., 1981b).

Siallitic brown and fersiallitic reddishbrown soils dominate the low and pre-mountain areas. The siallitic brown soils (without carbonate) have a variable depth: they usually have an $\mathrm{S}$ value ranging from 13 to $18 \mathrm{cmol}(+) \cdot \mathrm{kg}^{-1}$ on the south side, and from 24 to $50 \mathrm{cmol}$ $(+) \cdot \mathrm{kg}^{-1}$ (rarely) in the north, where generally have higher saturation. The siallitic brown soils (with carbonate) are abundant in the north side, and they are richer and more saturated than the above. CCB is usually between 47 and $78 \mathrm{cmol}^{(+)} \cdot \mathrm{kg}^{-1}$ and the CIC ranges from 49 to $80 \mathrm{cmol}(+) \cdot \mathrm{kg}^{-1}$ (Renda \& al., 
1980, 1981a, 1981b, 1982). The fersiallitic reddish-brown soils often eroded and usually with rocky outcrops and stones in the profile, have an approximated $\mathrm{S}$ value of $13 \mathrm{cmol}$ $(+) . \mathrm{kg}^{-1}$ on the southern slope (Renda \& al., 1980-81). In the north, they are somewhat richer, wherein the CCB ranges from 21 to 43 cmol $(+) \cdot \mathrm{kg}^{-1}$. They are mainly observed in rocks from the Cobre Group.

Over the granitoids, there are usually grayish brown soils, sometimes sandy and poor. Their $\mathrm{pH}$ goes from slightly acidic to acidic, with an $\mathrm{S}$ value of 4 to $5 \mathrm{cmol}(+) \cdot \mathrm{kg}^{-1}$ in the first horizon, and even lower below it.

In coastal limestone terraces, the very shallow red soils (rendzine) occupy the fractures and crevices of the dogtooth rock. A red ferrallitic soil is observed in coastal terraces, limestone hills and cumulative plains from Sierra Maestra's westernmost. It's CCB in the first horizon is $19 \mathrm{cmol}(+) \cdot \mathrm{kg}^{-1}$ and the $\mathrm{T}$ value is $24.3 \mathrm{cmol}(+) \cdot \mathrm{kg}^{-1}$. Both values decrease in the lower horizons (Renda \& al., 1981c).

In the higher areas of Sierra Maestra, it rains between 1600 and $2000 \mathrm{~mm}$, with a less rainy season from November to April (Trusov $\& a l ., 1983)$. It is noteworthy that cloud condensation is produced between 800 and 1200 $\mathrm{m}$ asl (horizontal precipitation, moist shade, low clouds). Hence, when it occurs, a $100 \%$ of relative humidity is reached; sometimes it runs by the stem (Boytel Yambú, 1972). On average, in Gran Piedra (weather station at $1100 \mathrm{~m}$ asl) there are 239 days a year affected by horizontal precipitation, of which 163 days have dense fog, from october to may occur 20 days or more per month (Montenegro, 1990).

In the higher parts of western Sierra Maestra, above $1500 \mathrm{~m}$ asl, the influence of such horizontal precipitations is almost daily. Air saturation, however, is almost little, even with dense fog, which is formed lower down and goes up with the wind. These conditions produce a high tension on the foliage, which may turn it into microphyll and the decomposition from withered leaves is very slow (Reyes \& Fornaris, 2011).

In Carso de Baire (north side), around 500 to $700 \mathrm{~m}$ asl, the mean annual rainfall varies from around $1200 \mathrm{~mm}$ in the less elevated areas up to more than $1600 \mathrm{~mm}$ in the highest (Gagua \& al., 1989). The average rainfall in La Tabla (600 $\mathrm{m}$ asl) is $1634 \mathrm{~mm}$, varying from 1216 to 2320 $\mathrm{mm}$ through the years: on average, there are 94 rainy days a year. A rainy period from March to November, with $85 \%$ of rainfall is clearly defined, as well as other less rainy from december to february with $15 \%$. The heaviest rainfall ranges between 5.1 and $30 \mathrm{~mm}$.
The coastal and pre-coastal strip, in the south of Sierra Maestra, is one of the most climatically extreme areas of Cuba. In the east of Santiago de Cuba's Bay, the weather is bixeric. The average rainfall hardly goes beyond the $700 \mathrm{~mm}$ a year. Exceeding the $100 \mathrm{~mm}$, the rainiest months are May, September and October; while the driest months are December, March and July, in which rarely exceed $30 \mathrm{~mm}$. The rainy days are usually less than 40 per year. To the west of the bay, rain increases gradually to about $1200 \mathrm{~mm}$ in front of Pico Turquino, where mountains plunge straight into the sea. From this point, rain then gradually decreases up to $800 \mathrm{~mm}$ near Cabo Cruz.

The air mean temperature in Gran Piedra $(1100 \mathrm{~m}$ asl $)$ is $18.4^{\circ} \mathrm{C}$; the average minimum is $15.7^{\circ} \mathrm{C}$ and the average maximum, $22.4^{\circ} \mathrm{C}$. On top of Pico Real del Turquino, the air mean temperature reaches about de $13^{\circ} \mathrm{C}$ (Montenegro, 1991a). On the north side, around the 500 and $700 \mathrm{~m}$ asl, the mean annual temperature is $20-22^{\circ} \mathrm{C}$ in the upper parts and $22-24^{\circ} \mathrm{C}$ in the lowest (Lapinel, 1989). By contrast, the mean annual temperature in the coastal zone ranges from $24-26^{\circ} \mathrm{C}$, with an average maximum of $30-32^{\circ} \mathrm{C}$, and an average minimum of $22-24^{\circ} \mathrm{C}$ (Montenegro, $1991 \mathrm{~b}$ ). The decrease in temperature per 100 $\mathrm{m}$ of elevation in western Sierra Maestra is $0.62^{\circ} \mathrm{C}$, and $0.66^{\circ} \mathrm{C}$ in the northern and southern sides respectively (Montenegro, 1991b).

At the top of Sierra de la Gran Piedra, relative humidity reaches high levels throughout the year, from just over $87 \%$ to about $92 \%$ among the different months. At 13:00 $\mathrm{h}$, it has a minimum between 80 and $86 \%$, and a maximum, at $07: 00 \mathrm{~h}$, from 88 to 92\% (Montenegro, 1990). The mean annual relative humidity in Carso de Baire is from 80 to $85 \%$ (Montenegro, 1991c) and in Contramaestre (bottom, north side), is of 52 to $60 \%$. In the coastal area, the mean annual relative humidity varies from 75 and $80 \%$, the mean annual at $13.00 \mathrm{~h}$ is from 70 to $75 \%$, and at $07: 00 \mathrm{~h}$, it is from 80 to $85 \%$ (Lapinel, 1989; Montenegro, 1991c). In Santiago de Cuba (lower part, southern slope) it varies between 47 and $60 \%$. At 13:00 h, such humidity increases with altitude from the bottom up to $1400 \mathrm{~m}$ asl, remaining constant to about $1600 \mathrm{~m}$ asl. Then it decreases to the top of Pico Real del Turquino (Montenegro, 1991c).

Evaporation in Gran Piedra is low and for eight months in the year, it does not exceed $100 \mathrm{~mm}$ per month (Montenegro, 1990). The months with the highest evaporation 
(Piche) are april, june, july and august (from 75 to $82 \mathrm{~mm}$ ), and with the smaller one, from october to january (less than $60 \mathrm{~mm}$ ) (Montenegro (1991d). In turn, in the coastal zone, evaporation fluctuates between 1900 and $2000 \mathrm{~mm}$ (Crespo, 1989). From March to September, it is over $110 \mathrm{~mm}$ (Piche), March, April, July and August are the months with the greater evaporation $(130-1400 \mathrm{~mm})$, and November and December show the smallest evaporation records, with $85 \mathrm{~mm}$ (Montenegro, 1991d). In Carso de Baire, the mean annual evaporation is of 1300 to $1500 \mathrm{~mm}$ (Montenegro, 1991d).

\section{Methodology}

The present paper used some data obtained from phytosociological studies (205 phytosociological plots from $625 \mathrm{~m}^{2}$ ) conducted in the forests of Sierra Maestra; some of them already published (Reyes \& Acosta, 2003, 2004; Reyes \& al., 2004a, b; Reyes \& Martínez, 2005) and some others still unpublished. These syntaxa are transformed into this forest typology using the standards of the Institute of Agro-Forestry Research (Del Risco, 2000a, b). The scrub syntaxa, grasslands, etc. were not taken into account in this study.

Two main types of indicators were considered:

- Forests characteristics.

- Oecotope characteristics.

\section{Forest Characteristics}

Del Risco (2000a, b) methodology for strata, vertical structure of canopy layer, abundance-coverage, presence degree and each species's participation was applied for studying the forest characteristics. Out of it, the characteristic combination of each forest type was created. In case of analogous forests, having a similar feature combination, the differential combination was determined. In addition, the canopy layer or sub-layer coverage was considered, as well as the shrub and herbaceous layers.

Strata (layers): Samek (1973) criteria for separating the three main strata (canopy, shrub, herbaceous and ferns) and the other synusiaes were used according to:

Canopy: Trees greater than $5 \mathrm{~m}$ in height.

Shrub: Shrubs and little trees between 1 and $5 \mathrm{~m}$.
Herbaceous: Plants under $1 \mathrm{~m}$. Ferns were considered separately; there are different types of terrestrial ferns. In some forest, they are found in the three layers described before, mainly in the herbaceous layer.

Lianas: It involves the different types of vines or lianas.

Epiphytes: Plants living over the phorophytes without being parasites. Sometimes they play an important role as indicators in different forest types, especially of environmental humidity.

Vertical structure of canopy layer (C/V). Components of this layer were individually calculated, directly on the plots. Kraft classification (in Samek, 1974) was used:

Predominant $(\mathrm{P})$ : The trees beyond the primary level.

Dominant (D): Those making up the main level.

Codominant (C): Those in the lower part of the primary level, but which are not well developed.

Intermediate (I): Those below the main level, which often form a sub-layer.

Oppressed $(\mathrm{O})$ : They are part of the bottom sub-layer. They have little vitality.

Abundance-Coverage (A-C). The projection of the crown or the number of individuals (only in the first two indices) was calculated, according to the modified scale of Braun Blanquet (1979). In this study, the scale from one to five was used. Each number represents a range from the A-C as discussed below. If there are two numbers, it means that the range varies between these two values. The scale is as follows:

1. Shortly rich or poor coverage. It covers up to $5 \%$ of the sample plot.

2. Little or too numerous, or coverage between 6 and $25 \%$.

3. Coverage between 26 and $50 \%$.

4. Coverage between 51 and $75 \%$.

5. Seventy six percent $(76 \%)$ or greater coverage.

Presence Degree (P-D). The existence of a species in the different sampled plots is conceived as presence. Values mean according to the number of times such species are found in the sampled plots and they are expressed in the following scale:

V. Constantly present: when species are observed in over $80 \%$ of the plots.

IV. Present most of the times: when species are found from 61 to $80 \%$.

III. Often present: when species are found between 41 and $60 \%$.

II. Rarely present: when species are present from 21 to $40 \%$.

I. Rare: when species are observed in less than $20 \%$ of the plots. 
Type of participation. It is the combination of the indices of abundance-coverage and the presence degree. It is considered as follows:

Main species: They are species having a presence degree of $\mathrm{V}$ and an abundance-coverage of two or greater.

Subdominant species: Species with a presence degree of $\mathrm{V}$ and an abundance-coverage lower than two or species with a presence degree of IV and any abundance-coverage.

Aggregated Species: Species with a presence degree of III, and any abundance-coverage.

Scattered Species: Species with a presence degree of II or I and any abundance-coverage.

Canopy layer coverage: It is the floor surface occupied by the horizontal projection of a plant foliage. It is calculated according to the classification of Samek (1974).

Superdense: When coverage is greater than $100 \%$. The branches of some individuals enter in the space of the crowns of the neighboring individuals.

Dense: Coverage between 91 and 100\%; branches touch each other. $90 \%$.

Slightly sparse: Coverage between 81 and

Sparse: Coverage between 51 and 80\%.

Very sparse: Coverage between 21 and $50 \%$.

A coverage lower than/below the $20 \%$ corresponds to a "clearing" with scattered trees.

Coverage of the shrub and herbaceous layers. The percentage of each of these layers is calculated as follows:

Very high: Coverage between 91 and $100 \%$.

High: Coverage of 51 to $90 \%$.

Media: Coverage between 21 and 50\%.

Low: Coverage below the $20 \%$.

Characteristic combination: It is the set of species that characterize and typify the forest type. It is formed by main, subdominant and aggregated species. When there is a group of species that differentiates similar forest types in oecotopes with some dissimilarity, it forms a differential combination. In these combinations, constant species (those having a V presence degree), and accompanying species (those having IV and III presence degree) were differentiated.

Oecotopes characteristics: The oecotope is the climatope (climatic conditions) and edatope (soil conditions: higrotope and trofotope) assembly. Sites that occupy tilted areas are influenced by physiographic characteristics. They will be therefore taken into account.

Physiographic characteristics: These observations are made in each plot alongside its surrounding area. The following parameters are determined: elevation above sea level, type of relief, exposure, slope in degrees, position on the slope (relative elevation) and microrelief.

Climatope characteristics: Sierra Maestra climatope was determined using the Borhidi (1996) bioclimate, with some modifications from Samek \& Travieso (1968), Montenegro (1990, 1991a, b, c, d, e) and Trusov \& al. (1983) in the parameters: temperature, mean multi-annual rainfall and dry months.

Edatope characteristics: In the plot and its surroundings, there are observed: rock and soil types, depth of solum, texture, structure, stoniness, gravelness and erosion. Besides, the organic layers ( $\mathrm{L}, \mathrm{F}$ and $\mathrm{H}$ ) and soil profile are described.

The trofotope (trophism) is studied: $\mathrm{A}=$ little fertile, $\mathrm{B}=$ moderately fertile, $\mathrm{C}=$ fertile and $\mathrm{D}=$ very fertile. The higrotope (soil moisture) is also studied, which according to the Pogrebnyak method (1955, in Samek, 1973) is classified as: $0=$ very dry, $1=$ dry, $2=$ fresh, 3 $=$ moderately wet and $4=$ wet.

The percentage of stone on the surface and the presence of dogtooth (lapiez) are classified as follows: less than $40 \%\left({ }_{x}\right), 40$ to $59 \%\left({ }_{x x}\right)$, $60 \%$ or more $\left({ }_{x x x}\right)$. The root mat has a vital role in nutrient cycle in some forests types, thereby it is important to take into account writing $\left(\mathrm{Rm}^{*}\right)$ when they have up to $10 \mathrm{~cm}$ and $\left(\mathrm{Rm}^{* *}\right)$ for more than $10 \mathrm{~cm}$.

Name of the forest type: To name the forest type, it is used the common name (Appendix 1) of two typical species from the characteristic combination (constant) of that type. The first one must belong to the canopy layer (constant and dominant) followed by another typical and constant species from any stratum. To differentiate some other types of forests more or less similar, the name of a typical and constant species from the differential combination is used, and then it is added to the previous name.

Through the characteristics of the oecotopes occupying the different forest types, it is possible to determine the relative qualities of the forest station or sites, which depends on the potential productive capacity (PPC), remaining defined five classes: excellent (I); good (II); regular (III); bad (IV) and very bad (V).

For forest management proposals, it is taken into account, in addition to the above, the floristic, syngenetic and physiognomic characteristics of forests (microphylly, mesophylly, size, degree of coverage, etc.); as well as the development strategies (nutrients circulation type), stages of degradation and strategies for rehabilitation and / or restoration.

Scientific names (genus, species and author) are fully written in Appendix 1. 


\section{Results and Discussion}

\section{Climatic type}

Tropical climate with two dry periods: Type of bioclimate with little extension in Sierra Maestra, due to the rain shadow of the mountains. The following subtype is observed:

5aTh. Extremely dry tropical bixeric climate: It is observed in the coastal strip (zone of wetlands and semi-deciduous microphyll forest) east of the bay of Santiago de Cuba. It is one of the most climatically extreme areas in Cuba; it rains a little less than $800 \mathrm{~mm}$ a year on average (arid climate); the rainy months are May, September and October exceeding $100 \mathrm{~mm}$; on the contrary, the driest ones are from december to March and July, in which hardly ever the rainfall goes over 30 $\mathrm{mm}$ (extremely dry). The rainy days are usually less than 40 per year. Evaporation ranges from 1900 to $2000 \mathrm{~mm}$ (Crespo, 1989). The increased evaporation months are March, April, July and August with 130 to $140 \mathrm{~mm}$ (Piche) and those with minor evaporation are November and December with 85 $\mathrm{mm}$ (Montenegro, 1991d). Mean annual temperature ranges from $24-26^{\circ} \mathrm{C}$, with a mean annual maximum of $30-32^{\circ} \mathrm{C}$ and a mean annual minimum of $22-24^{\circ} \mathrm{C}$ (Montenegro, 1991b).

Tropical climate with dry winter: This type of bioclimate is the most widespread in Sierra Maestra, with the exception of the upper parts and the coastal area in the southeast opposite side. The two following subtypes are found:

$4 \mathrm{bTh}$ - Tropical weather with 5 to 6 scarcely rainy months (medium-dry): It is observed on the "floor of semi deciduous forests and scrubs", longer spread to the west of the bay of Santiago de Cuba. The altitude ranges from sea level to $400-500 \mathrm{~m}$ asl in the northern and southern sides respectively; also, the mean annual temperature fluctuates between 24.5 and $26.0{ }^{\circ} \mathrm{C}$ and rainfall varies from 800 to $1200 \mathrm{~mm}$ (from low to medium rainy). Mean annual relative humidity is 75 to $80 \%$ and evaporation is 1700 to $1900 \mathrm{~mm}$ (Crespo, 1989; Montenegro, 1991d). To the west of the bay, rain increases gradually up to about $1200 \mathrm{~mm}$ (medium rainy) before Pico Turquino (where the mountains plunge straight into the sea), from this point, it gradually decreases to $800 \mathrm{~mm}$ near Cabo Cruz (little rainy).

$4 \mathrm{cTh}$ - Tropical climate with 3 to 4 little rainy months (moderately dry): It is observed on the "floor of evergreen forests", i.e., between 500 and $800 \mathrm{~m}$ asl. On the northern side, mean annual temperatures range between $21.3-23.1^{\circ} \mathrm{C}$ (top and bottom respectively), and $21.0-24.0^{\circ} \mathrm{C}$ on the southern slope (Montenegro, 1991b). The rainfall ranges from 1200 to $1800 \mathrm{~mm}$ (medium rainy to rainy), according to the locality. Relative humidity fluctuates during the year between 77 and $85 \%$ at $500 \mathrm{~m}$ asl and 84 to $92 \%$ at the top (Montenegro, 1991c). In Carso de Baire, mean annual evaporation is 1300 to $1500 \mathrm{~mm}$ (Montenegro, 1991d). In mountainous areas below $800 \mathrm{~m}$ above sea level, in the evenings and in mid-april to late October, relative sunshine (percentage of real sunshine regarding the astronomical one) varies between 20 and $30 \%$, the rest of the months is from 30 to $40 \%$. During the mornings, it ranges from 40 to $60 \%$ (Montenegro, 1991e).

Wet mountainous tropical climate: This kind of climate occurs in higher parts of Sierra Maestra, from $800 \mathrm{~m}$ asl and the top of Pico Turquino (maximum elevation of the Cuban archipelago, $1972 \mathrm{~m}$ asl). Two subtypes are observed:

$7 \mathrm{a}$ - Wet mountainous tropical climate: It occupies the "floor of the mountain rainforest", i.e. between 800 and $1500 \mathrm{~m}$ asl. Annual rainfall is $1600-2000 \mathrm{~mm}$, with a lower rainy period from November to April (Regal, 1988) and with a great influence of the horizontal precipitation: 239 days in Gran Piedra (1100 $\mathrm{m}$ asl; Montenegro, 1990). It is noteworthy that in this area the orographic cloud condensation occurs, which takes place between 800 and $1200 \mathrm{~m}$ asl; therefore, a $100 \%$ relative humidity is observed when it occurs, sometimes getting to flow through the stems (Boytel Yambú, 1972). Due to these horizontal rainfall in above $800 \mathrm{~m}$ asl areas (evenings), for 9 months, it does not exceed the $20 \%$ of relative sunshine, including four months in which it is less than $10 \%$. The other months it ranges between 20 and 30\%. During the mornings, it varies from 30 to $50 \%$. Throughout the year, such relative humidity reaches high values, from over $87 \%$ to nearby $92 \%$ among different months. The mean air temperature in Gran Piedra is $18.4^{\circ} \mathrm{C}$. Therefore, evaporation is low and for eight months in the year it does not exceed $100 \mathrm{~mm} / \mathrm{month}$ (Montenegro, 1991d). The zonal vegetation is mountain rainforest.

$7 \mathrm{~b}$ - Tropical climate of high mountain: This climatic type takes place on the "floor of cloud forests" from $1500 \mathrm{~m}$ above sea level to the top of Pico Real del Turquino (1972 $\mathrm{m}$ asl). The mean temperature fluctuates at $1500 \mathrm{~m}$ asl, between $14.1^{\circ} \mathrm{C}$ and $19.3^{\circ} \mathrm{C}$ in january and july respectively; in turn, at the top of Turquino, it reaches about de $13^{\circ} \mathrm{C}$ 
(Montenegro, 1991b). Rainfalls reach about $2000 \mathrm{~mm}$ (rainy weather). The influence of horizontal precipitations (orographic clouds and mists) is almost daily; however, on its outside, the forest experiences significant water stress due to the scarce air saturation (Reyes \& Fornaris, 2011). Compared to the "floor of the mountain rainforest", relative humidity decreases in these altitudes, averaging between 81 and $85 \%$ at $1500 \mathrm{~m}$ asl, and $82-83 \%$ on top of Turquino in dry and rainy periods respectively (Montenegro, 1991c). Sometimes, values of 36 and $40 \%$ are reached during the hottest hours (Reyes \& al., 2011).

\section{Forest Typology}

Due to the wide variety of oecotopes (types of weather, rocks and soils) and physiographic conditions (higher altitudes of the Cuban archipelago, sublatitudinal extension), Sierra Maestra has a great diversity of forest types. The main ones are:

\section{Uva caleta with yana (Coccoloba uvifera with Conocarpus erectus; Table 1)}

Physiognomy and floristic composition: This type of forest is known as sea-grape woodland and consists on a long and narrow tree strip dominated by Coccoloba uvifera (Table 1). Generally, its height does not exceed $8 \mathrm{~m}$, excepting in beaches, where it can reach about $15 \mathrm{~m}$. Due to the effect of the sea winds; it often forms an inclined plane, from near the ground to the appropriate height level.

Table 1. Characteristic combination of uva caleta with yana

(Coccoloba uvifera with Conocarpus erectus, 6 plots)

\begin{tabular}{|l|c|c|c|}
\hline Species & $\begin{array}{c}\text { Vertical } \\
\text { structure }\end{array}$ & $\begin{array}{c}\text { Abundance- } \\
\text { Coverage }\end{array}$ & Presence Degree \\
\hline \multicolumn{4}{|c|}{ Canopy layer } \\
\hline Coccoloba uvifera & $\mathrm{D}$ & 4 & $\mathrm{~V}$ \\
\hline Conocarpus erectus & $\mathrm{D}$ & 2 & $\mathrm{~V}$ \\
\hline
\end{tabular}

Scattered tree species: majagua de la florida (Thespesia populnea), ipil ipil (Leucaena leucocephala), vomitel (Cordia sebestena) and guacalote amarillo (Caesalpinia bonduc).

Oecotope characteristics. Due to its location near the sea, it is remarkably influenced by salt laden sea breezes (salt spray) and by the splashes during heavy swell, which changes the local climate. It is generally observed over the Cobre Group and sandy beaches; soils are sandy and gravelly, usually very shallow.

Terms for forest management. Since they protect surrounding vegetation from marine salt spray and they are a narrow strip, they must be protected against any human intervention, since they can be easily destroyed.

\section{Mangrove stands}

Mangroves are affected by marine and fresh water influence, which determines the corresponding type. Therefore, the local climatic conditions have their greatest impact in the farthest areas from the sea and the estuaries.

\section{Red mangrove community (Rhizophora mangle; Table 2)}

Physiognomy and floristic composition. This community is presented as a belt between 2 and $10 \mathrm{~m}$ wide where there is a very straightforward contact with the sea. It may reach higher values in flat areas. Its height is usually between 5 and $10 \mathrm{~m}$ and its structure is rather continuous, without defined layer. Regeneration is variable, sometimes scarce. Since it is exclusively composed by red mangrove (Rhizophora mangle), this forest forms a distinct ecosystem. Its anchoring aerial roots create special conditions for establishing and developing various types of fauna (Table 2). 
Oecotope characteristics. It occurs in lowlying places with sediment deposition, usually in areas protected from ocean streams. It is directly in contact with the ocean waves, and the places where tide variation gets its highest values. The substrate consists of quaternary sediments whose composition varies depending on the surrounding geology.

Distribution. It takes place in all the Cuban archipelago coasts.
Terms for forest management. It must be protected from any human intervention, since it forms a narrow strip and protects the coasts and the communities behind them. There are important areas that have been destroyed and should be therefore, restored. Recovery can be made by means of the propagules, which are born in the tree (viviparous capacity).

Table 2. Characteristic combination of the red mangrove community

(Rhizophora mangle, 10 plots)

\begin{tabular}{|l|c|c|c|}
\hline Species & $\begin{array}{c}\text { Vertical } \\
\text { structure }\end{array}$ & $\begin{array}{c}\text { Abundance- } \\
\text { Coverage }\end{array}$ & Presence Degree \\
\hline \multicolumn{4}{|c|}{ All layers } \\
\hline Rhizophora mangle & $\mathrm{D}$ & 5 & $\mathrm{~V}$ \\
\hline
\end{tabular}

\section{Community of red mangrove with black mangrove (Rhizophora mangle with Avicennia germinans; Table 3)}

Physiognomy and floristic composition. In San Miguel de Paradas, bay of Santiago de Cuba, this mixed mangrove stand forms a narrow belt of up to $70 \mathrm{~m}$; being lower in some other places. Such strip is only composed by red and black mangroves (Avicennia germinans) altogether (Table 3). Usually, the first one is more abundant before the sea. This is where it forms the bulk of the canopy layer in the first 7 to $15 \mathrm{~m}$; it appears later as seedlings in a forest dominated by the second type of mangrove. The canopy layer is between 10 and 12 $\mathrm{m}$ tall, with a dense coverage (around 90\%), while in the shrub layer it is almost always low (5 and 10\%); seedlings, on the other hand, show an average coverage from 20 to $50 \%$.

Oecotope characteristics. They are similar to those of the red mangrove community, although with less influence of waves.

Distribution. It comes after the red mangrove community, or in direct contact with the sea; therefore, it receives alongside the former community, the strongest tidal influence and the greatest depth of water. At certain times, such a water height is of at least 20 to $30 \mathrm{~cm}$ at low tide.

Terms for forest management. This kind of mangrove stand should be protected from human activities due to its coastal protection functions and narrow strip condition.

Table 3. Community of red mangrove with black mangrove

(Rhizophora mangle with Avicennia germinans, 10 plots)

\begin{tabular}{|l|c|c|c|}
\hline Species & $\begin{array}{c}\text { Vertical } \\
\text { structure }\end{array}$ & $\begin{array}{c}\text { Abundance- } \\
\text { Coverage }\end{array}$ & Presence Degree \\
\hline \multicolumn{4}{|c|}{ All layers } \\
Rhizophora mangle & $\mathrm{D}$ & 3 & $\mathrm{~V}$ \\
\hline Avicennia germinans & $\mathrm{D}$ & 2 & $\mathrm{~V}$ \\
\hline
\end{tabular}

Scattered tree species: white mangrove (Laguncularia racemosa)

\section{Community of black mangrove (Avicennia germinans; Table 4)}

Physiognomy and floristic composition. This type of mangrove stand is found throughout the study area and is generally predominant. It is located behind the red mangrove, and/or the red with black mangrove communities. It consists of pure populations of Avicennia germinans, which gives it a distinctive look. It shows its greatest height in the part in contact with the community of red mangrove, where it 
reaches between 10 and $12 \mathrm{~m}$. Behind this point, it only reaches from 3 to $6 \mathrm{~m}$ and can be considered as stunted mangroves. It is considerable the high density of pneumatophores, which are sometimes used as attachment points of seaweed and animals, and over which it is possible to walk easily (Table 4).

Oecotope characteristics. The soils are boggy (halomorphic) with quaternary sedi- ments. It is located in the area of tidal fluctuation and it is completely affected during high tide.

Distribution. They can be found in all coasts of the Cuban archipelago.

Terms for forest management. It must be protected like all mangrove communities. There are significant areas affected by human impact. Such areas should be restored in order to re-establish their role as protector of the coasts and the biodiversity.

Table 4. Characteristic combination of the black mangrove community (10 plots)

\begin{tabular}{|l|c|c|c|}
\hline Species & $\begin{array}{c}\text { Vertical } \\
\text { structure }\end{array}$ & $\begin{array}{c}\text { Abundance- } \\
\text { Coverage }\end{array}$ & Presence Degree \\
\hline \multicolumn{4}{|c|}{ All layers } \\
\hline Avicennia germinans & $\mathrm{D}$ & 5 & $\mathrm{~V}$ \\
\hline
\end{tabular}

\section{Black mangrove with acrostic (Avicennia germinans with Acrostichum danaefolium; Table 5)}

Physiognomy and floristic composition. This type of mangrove stand (Table 5) has a black mangrove canopy layer of 12 to $15 \mathrm{~m}$ high, with a cover from very sparse to sparce (40 to $70 \%$ ). The shrub layer is of acrostic (Acrostichum danaefolium), which reaches about 5 to $6 \mathrm{~m}$ and has a cover between high and very high (51 to $100 \%$ ).

Oecotope characteristics. It usually develops with freshwater influence, whose inten- sity determines the abundance of herbs.

Distribution. It is dispersed. It was studied at the northwestern edge of the mangrove stands of San Miguel de Paradas, where intermittent streams flow which cause significant freshwater input. Furthermore, it is little influenced by the tides, due to its geographical position in the mangrove stand.

Terms for forest management. Like other mangrove communities, it should be protected from all human activity.

Table 5. Black mangrove with acrostic

(Avicennia germinans with Acrostichum danaefolium, 5 plots)

\begin{tabular}{|l|c|c|c|}
\hline Species & $\begin{array}{c}\text { Vertical } \\
\text { structure }\end{array}$ & $\begin{array}{c}\text { Abundance- } \\
\text { Coverage }\end{array}$ & Presence Degree \\
\hline \multicolumn{4}{|c|}{ Canopy layer } \\
\hline Avicennia germinans & $\mathrm{D}$ & 3 & $\mathrm{~V}$ \\
\hline & \multicolumn{3}{|c|}{ Shrub layer } \\
\hline
\end{tabular}

\section{Black mangrove community with white mangrove (Avicennia germinans with Laguncularia racemosa; Table 6)}

Physiognomy and floristic composition. This type of forest, composed by white mangrove (Laguncularia racemosa) and black mangrove is very poorly represented and it is known as mixed mangrove. Sometimes it is put apart from the red mangrove by salt marshes of variable size. It reaches between 4 and $10 \mathrm{~m}$ in height and it often has underneath, seedlings of both species (Table 6).

Oecotope characteristics. The soils are weakly flooded. In some places, they are just directly affected by salt water during high tides. They are also influenced by the rainwater.

Distribution. It is commonly seen throughout the study area.

Terms for forest management. Like other mangrove communities, it should be protected from all human activity. 
Table 6. Black mangrove community with white mangrove

(Avicennia germinans with Laguncularia racemosa, 7 plots)

\begin{tabular}{|l|c|c|c|}
\hline Species & $\begin{array}{c}\text { Vertical } \\
\text { structure }\end{array}$ & $\begin{array}{c}\text { Abundance- } \\
\text { Coverage }\end{array}$ & Presence Degree \\
\hline \multicolumn{3}{|c|}{ All layers } \\
\hline Avicennia germinans & $\mathrm{D}$ & 3 & $\mathrm{~V}$ \\
\hline Laguncularia racemosa & $\mathrm{C}$ & 1 & $\mathrm{~V}$ \\
\hline
\end{tabular}

Scattered tree species: yana, cambrón (Prosopis juliflora)

Black mangrove with white mangrove and junco (Avicennia germinans with Laguncularia racemosa and Eleocharis mutata; Table 7)

Physiognomy and floristic composition. In San Miguel de Paradas, this forest is among the mangrove stands of black mangrove and black mangrove with acrostic, i.e., it comes after the latter into the mangrove stands. In addition to the black mangrove, there is often white mangrove in the canopy layer. It is 8 to $14 \mathrm{~m}$ high and its covers from very sparse to sparse $(21-70 \%)$. The shrub layer has a variable cover, media $(21-50 \%)$; while in the herbaceous layer is high $(51-80 \%)$. This type of mangrove stand is the richest in herbaceous species (Table 7).

Oecotope characteristics. Water usually varies between 2 and $10 \mathrm{~cm}$ above the substrate, strongly influenced by freshwater.

Distribution. It is in the northwestern part of the mangrove stands of San Miguel de Paradas in the bay of Santiago de Cuba.

Terms for forest management. Like other mangrove communities, it should be protected from all human activity.

Table 7. Black mangrove community with white mangrove and junco

(Avicennia germinans with Laguncularia racemosa and Eleocharis mutata, 7 plots)

\begin{tabular}{|c|c|c|c|}
\hline Species & $\begin{array}{l}\text { Vertical } \\
\text { structure }\end{array}$ & $\begin{array}{l}\text { Abundance- } \\
\text { Coverage }\end{array}$ & Presence Degree \\
\hline \multicolumn{4}{|c|}{ Canopy layer } \\
\hline Avicennia germinans & $\mathrm{D}$ & 3 & $\mathrm{~V}$ \\
\hline Laguncularia racemosa & $\mathrm{C}$ & 1 & III \\
\hline \multicolumn{4}{|c|}{ Herbaceous layer } \\
\hline Eleocharis mutata & - & 2 & $\mathrm{~V}$ \\
\hline Typha domingensis & - & 2 & $\mathrm{~V}$ \\
\hline Eleocharis.elegans & - & 1 & $\mathrm{~V}$ \\
\hline Cyperus giganteus & - & 1 & $\mathrm{~V}$ \\
\hline Scirpus olneyi & - & 1 & $\mathrm{~V}$ \\
\hline Cyperus alternifolius & - & 1 & III \\
\hline Ludwigia erecta & - & 1 & III \\
\hline Bacopa monnieri var. monnieri & - & 1 & III \\
\hline Alternanthera maritima & - & 1 & III \\
\hline \multicolumn{4}{|c|}{ Lianas } \\
\hline Mikania micrantha & - & 1 & III \\
\hline
\end{tabular}

Scattered tree species: yana. 
Yana community (Conocarpus erectus; Table 8)

Physiognomy and floristic composition. This type of mangrove stand (Table 8) is exclusively composed by yana (Conocarpus erectus). Stratification is continuous and dense $(100 \%)$ and can reach 8 to $12 \mathrm{~m}$ high.
Oecotope characteristics. Usually the ground is muddy and brown. It often occupies lagoon-like channels and is usually out of tidal influence.

Distribution. It is a highly disperse mangrove stand.

Terms for forest management. Like other mangrove communities, it should be protected from all human activity.

Table 8. Yana community (Conocarpus erectus), 6 plots

\begin{tabular}{|l|c|c|c|}
\hline Species & $\begin{array}{c}\text { Vertical } \\
\text { structure }\end{array}$ & $\begin{array}{c}\text { Abundance- } \\
\text { Coverage }\end{array}$ & Presence Degree \\
\hline \multicolumn{4}{|c|}{ All layers } \\
\hline Conocarpus erectus & $\mathrm{D}$ & 5 & $\mathrm{~V}$ \\
\hline
\end{tabular}

\section{Jatia with no me toques (Phyllostylon brasiliensis with Oplonia tetrasticha; Table 9)}

Physiognomy and floristic composition. This forest type is part of the semi-deciduous microphyll forest. The canopy layer is between 8 and 10 meters high, unusual if more. Its coverage is between 60 and $80 \%$, and considered as scarce. Within the group of constant species, only jatia [Phyllostylon brasiliensis $(=P h$. rhamnoides $)]$ is in the category of main species; baría (Cordia gerascanthus), carbonero (Colubrina elliptica) and chicharrón (Pseudocarpidium avicennioides) are subdominants. In the shrub layer, with a cover considered medium to high $(40-80 \%)$, no me toques (Oplonia tetrasticha) and Varronia globosa are main species; while picha de perro (Capparis flexuosa) and palo bronco (Malpighia suberosa) are subdominant species. In the herbaceous layer, cuaba de ingenio (Croton lucidus) is the main species, with a media average cover (20-50\%). As lianas and epiphytes, bejuco san pedro (Stigmaphyllon sagreanum) and curujey (Tillandsia recurvata) are subdominant species, respectively (Table 9).

In the group of accompanying species from the canopy layer, agalla de costa (Randia aculeata) is observed as subdominant. Negracuba (Thouinia patentinervis), majaguilla (Carpodiptera cubensis), aceituna (Picrodendron baccatum) and yuraguana (Coccothrinax gundlachii) are aggregated species. In the shrub layer, Pictetia mucronata, Tabebuia myrtifolia and frijolillo (Senna atomaria) are aggregated. In the herbaceous layer, Malpighia apiculata is considered as subdominant, while jijira (Harrisia eriophora), marilope (Turnera ulmifolia), jibá (Erythroxylum havanense) and anamú (Petiveria alliacea) are aggregated species. Among lianas, bejuco de purgación (Commicarpus scandens) is subdominant; and as aggregated species, there are bejuco angarilla (Serjania diversifolia), bejuco de berraco (Chiococca alba), amansa guapo (Triopteris rigida), Cynanchum sp. and bejuco uví (Cissus trifoliata). Curujey (Tillandsia fasciculata) and barba de indio (T. usneoides) are subdominant in the epiphyte synusiae.

Oecotope characteristics. The altitude varies between 10 and $80 \mathrm{~m}$ asl with an inclination between 25 and 45 degrees and an exposure mainly southward. It is located on the bottom of the mountains, near the sea, with a varied microrelief and strongly affected by the salt-laden sea winds (salt spray). This south-coastal area of Sierra Maestra, where this forest type ("floor of semi deciduous forests and scrubs") is observed, is under the effect of the rain shadow (wind screen, Föhn effect) provoked by these mountains; which means low rainfall, very warm temperature, low relative humidity and high evaporations rate.

To the east of the bay of Santiago de Cuba, there is an extremely dry tropical bixeric climate (5aTh) and rainfall is less than $700 \mathrm{~mm}$ a year on average. The rainiest months are May, September and October, with more than 100 $\mathrm{mm}$. The driest months are from December to March, and July, when barely exceeds the 30 $\mathrm{mm}$. The rainy days are usually less than 40 per year, being one of the most climatically extreme areas Cuba's, hence, it is considered a hot climate with two dry periods and more than six months of drought. To the west of the bay, rain increases gradually, changing to tropical climate with dry winter, 4bTh subtype, semi-dry, with 5 to 6 months with little rain. Precipitation falls from 900 to about $1200 \mathrm{~mm}$ in front of the Pico Turquino (where the moun- 
tains tumble directly into the sea), from where it gradually decreases to $800 \mathrm{~mm}$ near Cabo Cruz. The mean annual temperature ranges from 24 to $26^{\circ} \mathrm{C}$, with a mean maximum of 30 to $32^{\circ} \mathrm{C}$ and a mean minimum of 22 to 24 ${ }^{\circ} \mathrm{C}$ (Montenegro, 1991b). The mean annual relative humidity varies between 75 and $80 \%$, the mean annual at $13.00 \mathrm{~h}$ is 70 to $75 \%$, and from 80 to $85 \%$ at $07: 00 \mathrm{~h}$
(Lapinel, 1989; Montenegro, 1991b, c). Evaporation ranges between 1900 and 2000 $\mathrm{mm}$ (Crespo, 1989); from March to September it is over $110 \mathrm{~mm}$ (Piche), March, April, July and August are the months with higher evaporation (130 to $140 \mathrm{~mm}$ ) and November and December shows the smallest evaporation rates, $85 \mathrm{~mm}$ (Montenegro, 1991d).

Table 9. Characteristic combination of jatía with no me toques

(Phyllostylon brasiliensis with Oplonia tetrasticha, 7 plots)

\begin{tabular}{|c|c|c|c|}
\hline Species & $\begin{array}{l}\text { Vertical } \\
\text { structure }\end{array}$ & $\begin{array}{l}\text { Abundance- } \\
\text { Coverage }\end{array}$ & Presence Degree \\
\hline \multicolumn{4}{|c|}{ Canopy layer } \\
\hline Phyllostylon brasiliensis & $\mathrm{D}$ & 4 & $\mathrm{~V}$ \\
\hline Collubrina elliptica & $\mathrm{D}$ & 1 & V \\
\hline Pseudocarpidium avicennioides & $\mathrm{D}$ & 1 & V \\
\hline Cordia gerascanthus & $\mathrm{C}$ & 1 & $\mathrm{~V}$ \\
\hline Randia aculeata & I & 1 & IV \\
\hline Picrodendron baccatum & $\mathrm{C}$ & 1 & III \\
\hline Carpodiptera cubensis & $\mathrm{C}$ & 1 & III \\
\hline Thouinia patentinervis & $\mathrm{C}$ & 1 & III \\
\hline Coccothrinax gundlachii & $\mathrm{I}$ & 2 & III \\
\hline \multicolumn{4}{|c|}{ Shrub layer } \\
\hline Oplonia tetrasticha & - & 2 & $\mathrm{~V}$ \\
\hline Varronia globosa subsp. humilis & - & 2 & $\mathrm{~V}$ \\
\hline Capparis flexuosa & - & 1 to 2 & $\mathrm{~V}$ \\
\hline Malpighia suberosa & - & 1 & $\mathrm{~V}$ \\
\hline Tabebuia myrtifolia & - & 1 & III \\
\hline Pictetia mucronata & - & 1 & III \\
\hline Senna atomaria & - & 1 & III \\
\hline \multicolumn{4}{|c|}{ Herbaceous layer } \\
\hline Croton lucidus & - & 2 & $\mathrm{~V}$ \\
\hline Malpighia apiculata & - & 1 & IV \\
\hline Harrisia eriophora & - & 1 & III \\
\hline Turnera ulmifolia & - & 1 & III \\
\hline Erythro xylum havanense & - & 1 & III \\
\hline Petiveria alliacea & - & 1 & III \\
\hline \multicolumn{4}{|c|}{ Lianas } \\
\hline Stigmaphyllon sagreanum & - & 1 & $\mathrm{~V}$ \\
\hline Commicarpus scandens & - & 1 & IV \\
\hline Cynanchum sp. & - & 1 & III \\
\hline Cissus trifoliata & - & 1 & III \\
\hline Serjania diversifolia & - & 1 & III \\
\hline Chiococca alba & - & 1 & III \\
\hline Triopteris rigida & - & 1 & III \\
\hline \multicolumn{4}{|c|}{ Epiphytes } \\
\hline Tillandsia recurvata & - & 1 & $\mathrm{~V}$ \\
\hline Tillandsia fasciculata & - & 1 & IV \\
\hline Tillandsia usneoides & - & 1 & IV \\
\hline
\end{tabular}

Scattered species in the canopy layer: almácigo (Bursera simaruba), guásima (Guazuma ulmifolia), cafecillo (Bourreria virgata), yamaquey (Belairia spinosa) and aguedita (Picramnia pentandra).

Localities: Southern part of Sierra del Turquino. 
It is geologically located on rocks from the Cobre Group (Méndez \& al., 1994) and associated to limestone of Jaimanitas formation. There are mainly rocks and stones from the first group, mixed with the second's ones, although the reverse situation is also observed, i.e. limestone mixed with rocks and stones of the Cobre Group. The soil is reddish brown fersiallitic (Renda, 1989; Hernández \& al., 1994), very shallow, often gravelly, containing stones and rocks ranging from 60 to $90 \%$. Therefore, it can be considered as very dry $(0)$ and little fertile (A).

Because it grows in such difficult environmental conditions (shallow soil, high rockiness, stoniness, gravelness, high temperatures, high evaporation and marine salt spray influence), this forest is much stressed, which is expressed in its microphyll, sclerophyllous and semi-deciduous character (Reyes \& Acosta, 2004). Therefore, the potential productive capacity should be considered as very bad (V). The typology classification is as follows $\mathrm{A}_{\mathrm{xxx}} 0$, $5 \mathrm{aTh}_{\mathrm{a}}-4 \mathrm{bTh} \mathrm{b}_{\mathrm{bc}}, \mathrm{V}, \mathrm{Ph}$. b., O.t.

Distribution. This forest type had a much wider distribution in this coastal area, yet was studied in areas close to the coast of Sierra del Turquino and was observed in relatively large areas on both sides of the bay of Guantanamo and in scattered patches elsewhere.

Terms for forest management. Due to the ecological conditions in which it develops, this coastal forest has hardwood tree species and very slow growing, so handling should be especially careful. It must be protected in general, with 30-year-spaced selective interventions. Special care must be taken with regeneration, which is generally poor and scattered. There are plenty of coastal oecotopes adequate to restore this type of forest, which must be planted with jatía, as a main species, mixed with baría, almácigo, carbonero, majaguilla and negracuba. Climate change models predict increased drought in eastern Cuba (Álvarez \& Mercadet \& al., 2012). That is why, restoring this type of forest (due to its geographical position in the landscape) constantly raises its strategic value for protecting the coastal zone and the ecosystems behind from the effects of such climate changes.

\section{Carbonero with majagüilla de costa (Colubrina elliptica with Helicteres semitriloba; Table 10)}

Physiognomy and floristic composition. This forest type corresponds to a late secon- dary community of the semi-deciduous microphyll forest and is the stage fiera II under the conditions in which it takes place. The canopy layer is very sparse $(20 \%)$, occasionally more, and the height is 7 to $8 \mathrm{~m}$, in more developed areas it can reach up to $10 \mathrm{~m}$. As dominant species there is carbonero, and as co-dominant (subdominant species) there are majaguilla, almácigo and cafecillo. In the shrub layer, coverage is high (70 to $90 \%$ ); frijolillo and Varronia globosa subsp. humilis are the main species, while bayúa (Zanthoxylum elephantiasis) and picha de perro, are subdominant ones. The herbaceous layer coverage is high (60 to 70\%), with cuaba de ingenio (Croton lucidus) as the main species with high abundance - coverage, and tapa culo (Helicteres semitriloba) as subdominant. Among lianas, bejuco san pedro (Stigmaphyllon sagreanum) and bejuco de purgación are subdominants.

The group of accompanying species is numerous. In the canopy layer, negracuba, chicharrón (Pseudocarpidium avicennioides), Pictetia mucronata and yuraguana (Coccothrinax gundlachii) they are subdominants, with high abundance - coverage. In the shrub layer jibá is subdominant and in the herbaceous layer, the following species are also subdominant: no me toques, palo bronco (Malphigia suberosa), abrojo de costa (Castela spinosa), Zapoteca gracilis, Lantana montevidensis, marilope (Turnera ulmifolia), Crossopetalum sp., yerba de guinea (Urochloa humidicola) and camagueyana (Bothriochloa pertusa). Barba de indio (Tillandsia usneoides) and curujey (Tillandsia recurvata) are subdominant species among the epiphytes (Table 10).

Oecotope characteristics. It occupies the upper areas of the micro-basins, where part of the rain water does not infiltrate but drains into the lower areas, hence, the hydraulic stress is very pronounced. It takes place between 70 and $120 \mathrm{~m}$ asl The slope is very steep, 40 to 45 degrees; exposure varies between the south and the east. A tropical climate with dry winter, subtype $4 \mathrm{bTh}$, is observed with 5 to 6 months with little rain (semi-dry). The mean annual temperature ranges from $24-26^{\circ} \mathrm{C}$, with average picks of $30-32^{\circ} \mathrm{C}$ and $22-24^{\circ} \mathrm{C}$ respectively. The mean annual relative humidity is 75 to $80 \%$, this being 70 to $75 \%$ at $13: 00 \mathrm{~h}$ and from 80 to $85 \%$ at $07: 00 \mathrm{~h}$. Evaporations rate is $1700-1900 \mathrm{~mm}$ (Montenegro, 1991b, c, d). It rains about 1000 $\mathrm{mm}$, with a little rainy season from November to April and a rainy season from May to October. It is therefore considered a hot tropical climate with dry and semi-dry winter, 
with 5-6 dry months. Commonly, it is strongly affected by salt spray sea breezes.

Geologically, it is observed on rocks from the Cobre Group (Méndez \& al., 1994). The soil is fersiallitic reddish brown (Renda, 1989), yellowish, very shallow, very gravelly, highly eroded and has truncated profiles; the amount of stones on the surface is 60 to $90 \%$.
For all the difficult conditions of the oecotope: topographic position, soil, hydraulic stress, etc, this type of forest grows under extreme conditions, which is expressed in its microphyll and sclerophyllous nature. Therefore, it is considered as very dry (0) and little fertile (A). The typology classification is $\mathrm{A}_{\mathrm{xxx}} 0$, $4 \mathrm{bTh}, \mathrm{b}, \mathrm{V}$, C.e., H.s.

Table 10. Characteristic combination of carbonero with majagüilla de costa

(Colubrina elliptica with Helicteres semitriloba, 3 plots)

\begin{tabular}{|c|c|c|c|}
\hline Species & $\begin{array}{l}\text { Vertical } \\
\text { structure }\end{array}$ & $\begin{array}{c}\text { Abundance- } \\
\text { Coverage }\end{array}$ & Presence Degree \\
\hline \multicolumn{4}{|c|}{ Canopy layer } \\
\hline Colubrina elliptica & $\mathrm{D}$ & $2-5$ & $\mathrm{~V}$ \\
\hline Carpodiptera cubensis & $\mathrm{C}$ & 1 & $\mathrm{~V}$ \\
\hline Bursera simaruba & $\mathrm{C}$ & 1 & $\mathrm{~V}$ \\
\hline Bourreria virgata & $\mathrm{C}$ & 1 & $\mathrm{~V}$ \\
\hline Thouinia patentinervis & $\mathrm{C}$ & 4 & IV \\
\hline Pseudocarpidium avicennioides & $\mathrm{C}$ & 4 & IV \\
\hline Pictetia mucronata & $\mathrm{I}$ & 4 & IV \\
\hline Coccothrinax gundlachii & $\mathrm{I}$ & 4 & IV \\
\hline \multicolumn{4}{|c|}{ Shrub layer } \\
\hline Senna atomaria & - & 2 & $\mathrm{~V}$ \\
\hline Varronia globosa subsp. humilis & - & 2 & $\mathrm{~V}$ \\
\hline Zanthoxylum elephantiasis & - & 1 & $\mathrm{~V}$ \\
\hline Capparis flexuosa & - & 1 & $\mathrm{~V}$ \\
\hline Erythroxylum havanense & - & 1 & IV \\
\hline \multicolumn{4}{|c|}{ Herbaceous layer } \\
\hline Croton lucidus & - & 3 & $\mathrm{~V}$ \\
\hline Helicteres semitriloba & - & 1 & $\mathrm{~V}$ \\
\hline Oplonia tetrasticha & - & 1 & IV \\
\hline Malphigia suberosa & - & 1 & IV \\
\hline Castela spinosa & - & 1 & IV \\
\hline Zapoteca gracilis & - & 1 & IV \\
\hline Lantana montevidensis & - & 1 & IV \\
\hline Turnera ulmifolia & - & 1 & IV \\
\hline Crossopetalum sp. & - & 1 & IV \\
\hline Urochloa humidicola & - & 1 & IV \\
\hline Bothriochloa pertusa & - & 2 & IV \\
\hline \multicolumn{4}{|c|}{ Lianas } \\
\hline Stigmaphyllon sagreanum & - & 1 & $\mathrm{~V}$ \\
\hline Commicarpus scandens & - & 1 & $\mathrm{~V}$ \\
\hline \multicolumn{4}{|c|}{ Epiphytes } \\
\hline Tillandsia usneoides & - & 1 & IV \\
\hline Tillandsia recurvata & - & 1 & IV \\
\hline
\end{tabular}

Scattered species in the canopy layer: yarúa (Caesalpinia violacea), lirio santana (Exostema caribaeum) and jatía. Localities: in the pre mountain area of the southern slope of Sierra del Turquino. 
Distribution: It covers the bottom of the southern slope of Sierra del Turquino.

Terms for forest management. As it is a late secondary community with such difficult topographic and ecological conditions it must be protected, with the primary objective of preservation of the soil, the water and the micro-basins.

\section{Cuyá with guairaje (Sideroxylon salicifolium with Eugenia maleolens; Table 11)}

Physiognomy and floristic composition. Even when it has been relatively anthropized, the canopy layer of this semideciduous microphyll forest has between 8 and $12 \mathrm{~m}$ tall in its highest extension; exceptionally from 7 to $8 \mathrm{~m}$ with emerging from about 10 $\mathrm{m}$. Coverage is sparse to dense $(70-100 \%)$. In the group of constant species, the main species are: cuyá (Sideroxylon salicifolium), almácigo, yaití and guairaje (Eugenia maleolens). As subdominant species, there are: ciguilla (Guettarda elliptica), lirio santana and carbonero. In the shrub layer, whose cover is high $(50-80 \%)$, the subdominant species are yuraguana (Coccothrina fragans), cuabilla, carne de vaca (Maytenus buxifolia) and yarúa de costa (Erythroxylum rotundifolium); and in the herbaceous layer (medium cover), the subdominant is the jibá. There are different species among lianas (Table 11). In the group of accompanying species, in the canopy layer: yaya (Oxandra lanceolata), ipil ipil, guatapaná (Acacia macracantha) and macaguey (toad) (Guapira obtusata) are subdominant species. The shrub layer is poor and the herbaceous relatively rich (Table 11). Aggregated species are concentrated in the shrub and herbaceous layers and in the lianas synusiae.

Oecotope characteristics. The elevation is 40 to $80 \mathrm{~m}$ a.s.1, but not directly facing the sea. It is usually found on slopes of 28 from 40 degrees and exposure is to the north (NE to
NW), so it is protected from the marine salt spray.

In this area, rainfall is about $800 \mathrm{~mm}$, mainly concentrated from may to october; in turn, the humidity is low and temperatures and sunshine are very high, causing a large evaporation (Montenegro, 1991a, b, e; Crespo, 1989). It is considered as the beginning of the tropical climate zone with dry winter, semidry 4bTh subtype, with 5 to 6 months with little rain.

It is developed on marls from La Cruz formation. Soils are siallitic brown (sensu Hernández \& al., 1994), loamy, from very shallow to shallow, sometimes with gravel from the marl. Therefore this edatope must be considered dry (1) and little fertile (A), and the potential production capacity is considered bad (IV). The typology classification is as follows A1, $4 b T h$, IV, S.s., E.m.

Due to the steep slope, the withered leaves cover about $60 \%$ of the surface. It often accumulates in the anterior part of the stem, where it is thicker. The L layer ranges between 1 and $1.5 \mathrm{~cm}$. The $\mathrm{F}$ layer is about $0.5 \mathrm{~cm}$, but before the stems, it sometimes may be $1.0 \mathrm{~cm}$. The $\mathrm{H}$ layer is missing (Reyes \& Martinez, 2005).

Distribution. It is located in the coastal hills around the bay of Santiago de Cuba, in the south coastal terraces of Sierra Maestra (Núñez \& Viña, 1989).

Terms for forest management. According to the ecological conditions in which it develops, this coastal forest has semi-hard and hardwood tree species, as well as slow and very slow growing. Therefore, it should be carefully managed. It should be preserved for being an ecosystem of great importance for coastal protection. Interventions should be selective and spaced at least, 30 years. Regeneration should be protected, since it is generally dispersed. There are oecotopes showing adequate conditions to restore this kind of forest. They should be planted cuyá, jatía, almácigo, baría, carbonero, lirio santana and yarúa (Caesalpinia violacea). 
Table 11. Characteristic combination of cuyá with guairaje

(Sideroxylon salicifolium with Eugenia maleolens, 5 plots)

\begin{tabular}{|c|c|c|c|}
\hline Species & $\begin{array}{c}\text { Vertical } \\
\text { structure }\end{array}$ & $\begin{array}{c}\text { Abundance- } \\
\text { Coverage }\end{array}$ & Presence Degree \\
\hline \multicolumn{4}{|c|}{ Canopy layer } \\
\hline Sideroxylon salicifolium (Dipholis salicifolia) & $\mathrm{D}$ & 2 & $\mathrm{~V}$ \\
\hline Bursera simaruba & $\mathrm{D}$ & 2 & $\mathrm{~V}$ \\
\hline Gymnanthes lucida & $\mathrm{I}$ & 2 & $\mathrm{~V}$ \\
\hline Eugenia maleolens & I & 3 & $\mathrm{~V}$ \\
\hline Guettarda elliptica & I & 1 & $\mathrm{~V}$ \\
\hline Exostema caribaeum & I & 1 & $\mathrm{~V}$ \\
\hline Colubrina elliptica & I & 1 & $\mathrm{~V}$ \\
\hline Oxandra lanceolata & I & 1 & IV \\
\hline Leucaena leucocephala & I & 2 & IV \\
\hline Guapira obtusata & I & 1 & IV \\
\hline Acacia macracantha & $\mathrm{O}$ & 1 & IV \\
\hline \multicolumn{4}{|c|}{ Shrub layer } \\
\hline Randia aculeata & - & 1 & $\mathrm{~V}$ \\
\hline Coccothrinax fragans & - & 1 & $\mathrm{~V}$ \\
\hline Amyris elemifera & - & 1 & $\mathrm{~V}$ \\
\hline Maytenus buxifolia & - & 1 & $\mathrm{~V}$ \\
\hline Erythroxylum rotundifolium & - & 1 & $\mathrm{~V}$ \\
\hline \multicolumn{4}{|c|}{ Herbaceous layer } \\
\hline Erythroxylum havanense & - & 1 & $\mathrm{~V}$ \\
\hline Randia spinifex & - & 1 & IV \\
\hline Melicoccus bijugatus & - & 1 & IV \\
\hline Croton lucidus & - & 1 & IV \\
\hline Drypetes $\mathrm{sp}$. & - & 1 & IV \\
\hline Scleria lithosperma & - & 1 & IV \\
\hline Panicum sp. & - & 1 & IV \\
\hline Zanthoxylum fagara & - & 1 & III \\
\hline Celtis trinervia & - & 1 & III \\
\hline Thouinia trifoliata & - & 1 & III \\
\hline Canella winterana & - & 1 & III \\
\hline Ravenia leonis & - & 2 & III \\
\hline Zapoteca gracilis & - & 1 & III \\
\hline \multicolumn{4}{|c|}{ Lianas } \\
\hline Chiococca alba & - & 1 & $\mathrm{~V}$ \\
\hline Smilax havanensis & - & 1 & $\mathrm{~V}$ \\
\hline Stigmaphyllon sagreanum & - & 1 & $\mathrm{~V}$ \\
\hline Passiflora suberosa & - & 1 & $\mathrm{~V}$ \\
\hline Capparis flexuosa & - & 1 & IV \\
\hline C. cynophallophora & - & 1 & IV \\
\hline Lasiacis divaricata & - & 1 & IV \\
\hline Gouania lupuloides & - & 1 & III \\
\hline Capparis grisebachii & - & 1 & III \\
\hline Dalechampia scandens & - & 1 & III \\
\hline
\end{tabular}

Scattered species in the canopy layer: aguedita (Picramnia pentandra), peonía (Citharexylum sp.), yarúa, roble prieto (Ehretia tinifolia), Licaria sp., abey macho (Jacaranda coerulea) and espuela de caballero (Bucida spinosa). 
Macaguey (toad) with curujey and chicharrón (Guapira obtusata with Hohenbergia penduliflora and Drypetes mucronata; Table 12)

Physiognomy and floristic composition. The canopy layer is irregular in height, usually between 7 and $12 \mathrm{~m}$, its cover is sparse (50$60 \%$ ) and is considered a clear microphyll evergreen forest; the leaves are mainly xeromorphic and mostly microphyllous. In the group of constant species the macaguey (toad) is the main specie, and as subdominant there are lirio amarillo or suchel (Plumeria emarginata), ayúa de sierra (Zanthoxylum cubense), chicharrón (Drypetes mucronata), bone (Drypetes alba), yuraguana (Coccothrinax elegans) and Tabebuia bibracteolata. The shrub layer has a medium to high covers (30-60\%), occasionally less. The subdominant species are sigua (Ocotea coriacea), hicaquillo (Savia bahamensis) and yarúa de costa (Erythroxylum rotundifolium). The herbaceous layer, in which there are many species considered as epiphytes in other ecosystems, has a high cover (80-90\%). The main species are maguey (Agave underwoodii), no me toques, curujey (Hohenbergia penduliflora), curujey (Tillandsia fasciculata), and as subdominant, flor del cáliz (Selenicereus grandiflorus), jijira (Pilosocereus brooksianus), bejuco lombricero (Philodendron lacerum), Polypodium polypodioides, Epidendrum pygmaeum and flor de san pedro (Epidendrum nocturnum). In the lianas, bejuco de berraco, alambrillo (Smilax havanensis), bejuco san pedro, Platygyne dentata and bejuco manteca (Passiflora penduliflora) are subdominants. Among the epiphytes the main species is barba de indio and the curujeyes (Tillandsia recurvata and $T$. pruinosa) are subdominants.

In the group of accompanying species, the subdominants in canopy layer are: carbonero, carmín (Alvaradoa arborescens) and cuabilla (Amyris elemifera). In turn, in the shrub layer aguedita (Celtis trinervia), cuaba prieta (Erithalis fruticosa), negracuba, yaití (Gymnanthes lucida), brasil (Caesalpinia vesicaria) and picha jutía (Hyperbaena paucinervis) have the same category; as well as aguedita (Picramnia pentan$d r a$ ), cañuela (Cyrtopodium punctatum), disciplinilla (Rhipsalis cassutha), among others within the herbaceous layer. Aggregated species are also diverse (Table 12).

This kind of forest have a rich differential combination that distinguish it from macaguey (toad) with curujey and lirio santana (Guapira obtusata with Hohenbergia penduliflora and Exostema caribaeum) (Table 11), due to some rain and altitudinal differences.
Oecotope characteristics. This kind of forest is present at the top of the mogotes (karstic dome hill) with a 600 to $670 \mathrm{~m}$ asl altitude. The microrelief is diverse, composed by big, sharp, with lots of holes and ruptures dogtooth rocks. The average exposure to sun light in this zone is of 3 to 5 hours per day, with lower and higher peaks during the rainy and dry seasons respectively. The mean annual temperature is $20-22^{\circ} \mathrm{C}$, with a mean minimum of 16 $18^{\circ} \mathrm{C}$ and a mean maximum of $26-28^{\circ} \mathrm{C}$ (Montenegro, 1991b, e). The climate is tropical with $4 \mathrm{cTh}$ subtype dry winter and 3 to 4 months with little rain (moderately dry), the average rainfall is $1634 \mathrm{~mm}$ in La Tabla (1216 to $2320 \mathrm{~mm}$ ), so it can be regarded as rainy (sensu Borhidi, 1991). On average there are 94 rainy days in the year. A rainy season is clearly defined from march to october with $85 \%$ of the rainfall while the dry season takes only the $15 \%$ of it. The mean annual relative humidity is $80-85 \%$, ranging between a $60-70 \%$ at 13.00 $\mathrm{h}$, and $85-90 \%$ at $07.00 \mathrm{~h}$ (Montenegro, 1991c, d). The mean annual evaporation is 1300 to $1500 \mathrm{~mm}$, with a daily average of $2.5-3 \mathrm{~mm}$ (Piche) and up to $3.5-4 \mathrm{~mm}$ in sunny days (Montenegro, 1991d).

These mogotes are strongly carsified and dissected denude plateaus (Viña Bayes, 1991), with vertical walls, composed by limestones and marbles from Charco Redondo formation. Because of its topographic position, this forest is in a very irregular microrelief, with big, sharp, with lots of holes and ruptures dogtooth rocks, where sometimes there is a red, very shallow soil. That is why it is considered dry (1), with a little fertile (A) trophism.

However, withered leaves accumulates in the holes, sometimes reaching up to $20 \mathrm{~cm}$, and form a root mat, where nutrient recycling takes place. The ecosystem depends on this recycling. Due to the particular conditions of this forest, the potential productive capacity is considered very bad (V). The typology classification is as follows $\mathrm{A}_{\mathrm{xxx}} 1,4 \mathrm{cTH}_{\mathrm{d}}$, V, G.o., H.p., D.m.

Distribution. This area of mogotes, where this forest type develops, occurs in the northern slope of Sierra Maestra, forming the central part of a typical territory known as Carso de Baire (La Tabla, Palma del Perro).

Terms for forest management. Due to the difficult environmental conditions where these forests evolved and their topographical position, the hardwood species with a very slow growth predominate. Therefore, it is considered a typical object of conservation and should not be exploited at any circumstances. 
Table 12. Characteristic combination of macaguey (toad) with curujey and chicharrón (Guapira obtusata with Hohenbergia penduliflora and Drypetes mucronata, 4 plots)

\begin{tabular}{|c|c|c|c|}
\hline Species & $\begin{array}{c}\text { Vertical } \\
\text { structure }\end{array}$ & $\begin{array}{l}\text { Abundance- } \\
\text { Coverage }\end{array}$ & Presence Degree \\
\hline \multicolumn{4}{|c|}{ Canopy layer } \\
\hline Guapira obtusata & $\mathrm{D}$ & $2-3$ & V \\
\hline Zanthoxylum cubense & $\mathrm{C}$ & 1 & $\mathrm{~V}$ \\
\hline Drypetes alba & $\mathrm{C}$ & 1 & $\mathrm{~V}$ \\
\hline Coccothrinax elegans & I & 1 & V \\
\hline Tabebuia bibracteolata & I & 1 & V \\
\hline Plumeria emarginata & I & 1 & $\mathrm{~V}$ \\
\hline Colubrina elliptica & I & 1 & IV \\
\hline Alvaradoa arborescens & I & 1 & IV \\
\hline Amyris elemifera & $\mathrm{I}$ & 2 & IV \\
\hline Spirotecoma sp. & $\mathrm{O}$ & 1 & III \\
\hline \multicolumn{4}{|c|}{ Shrub layer } \\
\hline Ocotea coriacea & - & 1 & $\mathrm{~V}$ \\
\hline Savia bahamensis & - & 1 & $\mathrm{~V}$ \\
\hline Celtis trinervia & - & 1 & IV \\
\hline Hyperbaena paucinervis & - & 1 & IV \\
\hline \multicolumn{4}{|c|}{ Herbaceous layer } \\
\hline Agave underwoodii & - & 3 & $\mathrm{~V}$ \\
\hline Hohenbergia penduliflora & - & 3 & $\mathrm{~V}$ \\
\hline Tillandsia fasciculata & - & 3 & $\mathrm{~V}$ \\
\hline Oplonia tetrasticha & - & 2 & $\mathrm{~V}$ \\
\hline Pilosocereus brooksianus & - & 1 & $\mathrm{~V}$ \\
\hline Philodendron lacerum & - & 1 & $\mathrm{~V}$ \\
\hline Selenicerus grandiflorus & - & 1 & $\mathrm{~V}$ \\
\hline Epidendrum nосturnum & - & 1 & $\mathrm{~V}$ \\
\hline Grisebachianthus plucheoides & - & 1 & IV \\
\hline Zamia angustifolia & - & 1 & IV \\
\hline Vanilla sp. & - & 1 & IV \\
\hline Arthrostylidium angustifolium & - & 2 & IV \\
\hline Croton lucidus & - & 1 & III \\
\hline Vernonia sp. & - & 1 & III \\
\hline Ilex sp. & - & 1 & III \\
\hline Pharus glaber & - & 1 & III \\
\hline \multicolumn{4}{|c|}{ Lianas } \\
\hline Smilax havanensis & - & 1 & $\mathrm{~V}$ \\
\hline Chioccoca alba & - & 1 & $\mathrm{~V}$ \\
\hline Stigmaphyllon sagreanum & - & 1 & $\mathrm{~V}$ \\
\hline Platygyna dentata & - & 1 & $\mathrm{~V}$ \\
\hline Capparis flexuosa & - & 1 & III \\
\hline Cynanchum sp. & - & 1 & III \\
\hline \multicolumn{4}{|c|}{ Epiphytes } \\
\hline Tillandsia usneoides & - & 2 & $\mathrm{~V}$ \\
\hline Tillandsia recurvata & - & 1 & $\mathrm{~V}$ \\
\hline \multicolumn{4}{|c|}{ Differential combination from macaguey (toad) with curujey and chicharrón } \\
\hline Drypetes mucronata & $\mathrm{C}$ & 1 & $\mathrm{~V}$ \\
\hline Erythroxylum rotundifolium & - & 1 & $\mathrm{~V}$ \\
\hline Polypodium polypodioides & - & 1 & $\mathrm{~V}$ \\
\hline Epidendrum pygmaeum & - & 1 & $\mathrm{~V}$ \\
\hline Passiflora penduliflora & - & 1 & $\mathrm{~V}$ \\
\hline Tillandsia pruinosa & - & 1 & $\mathrm{~V}$ \\
\hline Erithalis fruticosa & - & 1 & IV \\
\hline Thouinia trifoliata & - & 1 & IV \\
\hline
\end{tabular}




\begin{tabular}{|l|c|c|c|}
\hline Gymnanthes lucida & - & 1 & IV \\
\hline Caesalpinia vesicaria & - & 1 & IV \\
\hline Picramnia pentandra & - & 1 & IV \\
\hline Trichocentrum undulatum & - & 1 & IV \\
\hline Cyrtopodium punctatum & - & 1 & IV \\
\hline Rhipsalis cassutha & - & 1 & IV \\
\hline Polypodium aureum & - & 1 & IV \\
\hline Encyclia sp. & - & 1 & IV \\
\hline Octomeria tridentata & - & 1 & IV \\
\hline Pleurothallis gelida & - & 1 & IV \\
\hline Campiloneurum phyllitidis & - & 1 & IV \\
\hline Gesneria heterochroa & - & 1 & III \\
\hline Auerodendron cubensis & - & 1 & III \\
\hline Solandra longiflora & - & 1 & III \\
\hline Isidorea polyneura & - & 1 & III \\
\hline Peperomia rotundifolia & - & 1 & III \\
\hline Guzmania monostachya & - & 1 & III \\
\hline Tillandsia schiediana & - & 1 & III \\
\hline T. balbisiana & - & 1 & III \\
\hline
\end{tabular}

Scattered species in the canopy layer: jaguey (Ficus laevigata), ramon cow (Dendropanax arboreus), lirio santana and jaguey (Ficus perforata).

Localities: Carso de Baire.

\section{Macaguey (toad) with curujey and lirio santana (Guapira obtusata with Hohenbergia penduliflora and Exostema caribaeum; Table 13)}

Physiognomy and floristic composition. The canopy layer of this clear-microphyll evergreen forest varies between 7 and $12 \mathrm{~m}$ in height and its cover is sparse (50-60\%). In the group of constant species, the main species is macaguey (toad) and the subdominants are yuraguana (Coccothrinax elegans) and Tabebuia bibracteolata. In the shrub layer, with variable coverage between low and high (15 and $80 \%$ ), is only subdominant sigua (Ocotea coriacea). In the herbaceous layer, with a high cover (50 and $80 \%$ ), no me toques and curujeyes (Hohenbergia penduliflora and Tillandsia fasciculata) are the main species. Concerning lianas, alambrillo, bejuco de verraco, bejuco lombricero and flor del cáliz are subdominants. In the group accompanying species, in the canopy layer, cuabilla, bone and suchel are subdominants. Other species from the shrub and herbaceous layers, and lianas are found in Table 13. In the canopy layer, among the aggregate species group, there are ayúa de sierra (Zanthoxylum cubense), carmín and few species in other strata and synusiaes. Also, lirio santana (Exostema caribaeum), panetela (Phyllanthus epiphyllanthus) and pasionaria de cerca (Passiflora sexflora) are present in the differential combination.
Oecotope characteristics. Because it is also developed in the top of the mogotes of Carso de Baire, the ecological conditions and forest management are the same of the forest previously described [macaguey (toad) with curujey and chicharron]. However, there are some differences in its distribution, since this forest is located in Las Manuelas and in La Pimienta. Thus, it is somewhat lower and higher than the other described forest, respectively, which may result in some rainfall differences. The typology classification is as follows $\mathrm{A}_{\mathrm{xxx}} 1$, $4 \mathrm{cTh}$, V, G.o., H.p., E.c.

\section{Sigua with carmín (Ocotea coriacea with Alvaradoa arborescens)}

Physiognomy and floristic composition. This type of forest (2 plots) is an early community; it comes from excessive disturbance and fire, so it is currently a homeostasis I. Carmín (Alvaradoa arborescens) is the main species that make the current stability. The canopy layer is quite uneven, with a height between 6 and $11 \mathrm{~m}$; the coverage is sparse, ranging between 60 and $70 \%$. The most abundant species are carmín (D, A-C 3-4), sigua (D, A-C 1-2) and sometimes lirio amarillo (C, A-C 1), macaguey (toad) (I, A-C 1), ayúa de sierra (I, A-C 1), picha jutía (Hyperbaena paucinervis, 0, A-C 1), penda (I, A-C 1), lirio santana (I, A-C 1), carbonero (I, A-C 1) and 
guamá (Lonchocarpus longipes, $0, \mathrm{~A}-\mathrm{C} 1$ ) are also seen in this layer. Other scattered tree species are: raspalengua (Casearia hirsuta), aguedita sweet, aguedita (Picramnia pentandra), yaití, cuabilla and pole box (Allophyllus cominia).
In the shrub layer, coverage is high $(50-60 \%)$, and it is media at the herbaceous $(30-40 \%)$, which is also the richest in species.

Table 13. Characteristic combination of the forest macaguey (toad) with curujey and lirio santana (Guapira obtusata with Hohenbergia penduliflora and Exostema caribaeum, 5 plots)

\begin{tabular}{|c|c|c|c|}
\hline Species & $\begin{array}{l}\text { Vertical } \\
\text { structure }\end{array}$ & $\begin{array}{l}\text { Abundance- } \\
\text { Coverage }\end{array}$ & Presence Degree \\
\hline \multicolumn{4}{|c|}{ Canopy layer } \\
\hline Guapira obtusata & $\mathrm{D}$ & 3 & $\mathrm{~V}$ \\
\hline Coccothrinax elegans & $\mathrm{C}$ & 1 & $\mathrm{~V}$ \\
\hline Tabebuia bibracteolata & I & 1 & $\mathrm{~V}$ \\
\hline Amyris elemifera & I & 1 & IV \\
\hline Hyperbaena paucinervis & $\mathrm{O}$ & 1 & IV \\
\hline Drypetes alba & $\mathrm{O}$ & 1 & IV \\
\hline Plumeria emarginata & $\mathrm{O}$ & 1 & IV \\
\hline Zanthoxylum cubense & $\mathrm{C}$ & 1 & III \\
\hline Alvaradoa arborescens. & I & 1 & III \\
\hline \multicolumn{4}{|c|}{ Shrub layer } \\
\hline Ocotea coriacea & - & 1 & $\mathrm{~V}$ \\
\hline Savia bahamensis & - & 1 & III \\
\hline \multicolumn{4}{|c|}{ Herbaceous layer } \\
\hline Oplonia tetrasticha & - & 2 & $\mathrm{~V}$ \\
\hline Hohenbergia penduliflora & - & 2 & V \\
\hline Tillandsia fasciculata & - & 2 & $\mathrm{~V}$ \\
\hline Agave underwoodii & - & 2 & IV \\
\hline Vernonia sp. & - & 1 & IV \\
\hline Grisebachianthus plucheoides & - & 1 & IV \\
\hline Pilosocereus brooksianus & - & 1 & IV \\
\hline Epidendrum nocturnum & - & 1 & III \\
\hline \multicolumn{4}{|c|}{ Lianas } \\
\hline Philodendron lacerum & - & 1 & V \\
\hline Selenicerus grandiflorus & - & 1 & V \\
\hline Smilax havanensis & - & 1 & V \\
\hline Chioccoca alba & - & 1 & $\mathrm{~V}$ \\
\hline Vanilla $\mathrm{sp}$. & - & 1 & III \\
\hline Stigmaphyllon sagreanum & - & 1 & III \\
\hline \multicolumn{4}{|c|}{ Epiphytes } \\
\hline Tillandsia usneoides L. & - & 1 & IV \\
\hline \multicolumn{4}{|c|}{ Differential combination from macaguey (toad) with curujey and lirio santana } \\
\hline Exostema caribaeum & - & 1 & III \\
\hline Phyllanthus epiphyllanthus & - & 1 & III \\
\hline Passiflora sexflora & - & 1 & III \\
\hline
\end{tabular}

Scattered species in the canopy layer: baría, mabóa de sabana (Cameraria retusa), penda (Citharexylum caudatum), carbonero and guairaje (Eugenia asperifolia). 
Ecology and distribution. It comes on top of the strongly dissected carsified plateaus, mogotes, which occupies the geographical area known as Carso de Baire. The altitude varies between 600 and $650 \mathrm{~m}$ asl Weather conditions are described in macaguey (toad) with curujey and chicharrón, since they are located in the same territory. Although it is at the top of the mogotes, it occupies the edatopes with shallow to very shallow soils, with about $40 \%$ of rocks on the surface. Because of its topographic position, it is exposed to the average climatic conditions of the region. The L layer is variable in site, it ranges between 0.5 to $2 \mathrm{~cm}$, the $\mathrm{F}$ layer fluctuate from 0.2 to $1 \mathrm{~cm}$ and the $\mathrm{H}$ layer occasionally it reaches $1.5 \mathrm{~cm}$, with rootlets.

As the general conditions are similar to macaguey (toad) with curujey and chicharrón, therefore it is also considered a typical object of conservation and should not be exploited at any circumstances. The typology classification is considered B1, 4cTh ${ }_{d}$, IV, O.c., A.b.

\section{Jocuma with guao (Sideroxylum foetidissimum subsp. foetidissimum with Comocladia dentata; Table 14)}

Physiognomy and floristic composition. This semideciduous microphyll forest was altered by intense selective logging, which has changed its structure. However, it maintains its floristic composition; therefore, nowadays, it can be rehabilitated.

The canopy layer is between 7 and $10 \mathrm{~m}$ in height, so it is considered a low forest. It has also emerging about $15 \mathrm{~m}$. Cover is very sparse $(30-50 \%)$. The main species are jocuma (Sideroxylon foetidissimum subsp. foetidissimum) and guao (Comocladia dentata). The subdominant species are almácigo, sigua (sometimes abundant), cuyá, lirio santana (locally abundant), guara (Cupania glabra), jía blanca (Adelia ricinella) and aroma blanca (Alvaradoa amorphoides). In the canopy layer of the group of accompanying species, yaicuaje (Exothea paniculata) is subdominant.

The shrub layer has a high cover (80 to $90 \%$ ). Subdominant and abundant are guairaje (Eugenia sp.) and guao, there are too raspalengua and the jibá, among others species. In the herbaceous layer with an average from 20 to $30 \%$, are present Zapoteca gracilis, amor seco (Desmodium incanum), cortadera (Scleria lithosperma) and canutillo (Commelina elegans). Lianas are diverse. The composition of the other strata and synusiaes (which are many) is found in Table 14.
Oecotope characteristics. This forest is present in small altitudes, between 230 and $240 \mathrm{~m}$ asl The slope is small, about 5 degrees, with a relatively uniform meso and microrelief. The exposure is varied. Climatically, it is in the area where the influence of Sierra Maestra ends. It has a tropical climate with dry winter, 4bTh subtype, with 5 to 6 months with little rain (semidry). In the area, it rains between 1000 and $1200 \mathrm{~mm}$ (medium rainy), distributed in a rainy season from May to October, and a less rainy from November to April. It has from 40 to 60 days with precipitation annually. The mean relative humidity is 75 to 80\% (Montenegro, 1991b, c) and evaporation varies between 2000 and $2200 \mathrm{~mm}$ (Crespo, 1989). The mean annual temperature ranges from $24-26^{\circ} \mathrm{C}$, with an average high of $32-34^{\circ} \mathrm{C}$ and an average low of $18-20^{\circ} \mathrm{C}$.

It occurs in limestone from Charco Redondo geological formation. The soil is brown, very shallow, sometimes rocks cover up to $80 \%$ of the surface. Withered leaves have an L layer between 2 and $2.5 \mathrm{~cm}$, and an $\mathrm{F}$ layer of 0.5 to $1 \mathrm{~cm}$. The $\mathrm{H}$ layer is thin and forms a root mat of around $1 \mathrm{~cm}$ in some places. It is hence considered as a dry and moderately fertile edatope. Therefore, its potential productive capacity is considered bad (IV). The typology classification is as follows B1, 4bTH, IV, Rm*, S.f.f., C.d.

Distribution. This forest has a more widespread distribution in the hills of the northern slope of Sierra Maestra. It was studied at the place known as El Granizo, between Jiguaní and Baire, in the hills of northern edge of Sierra Maestra.

Terms for forest management. As intervention continues, this forest has lost part of its structure. However, there are many valuable species from the forestry point of view, which have an acceptable participation in the canopy layer and a very good regeneration (jocuma, cuyá, sigua, guara, yaicuaje). Therefore, interventions should be limited to restrict guao and frijolillo in the canopy layer and release the seedlings of the most valuable species in the lower ones. It can be also enriched with mahogany (Swietenia mahagoni), cedar (Cedrela odorata), yarúa, etc.

\section{Group of cuyá with cúrbana (Sideroxylon salicifolium with Canella winterana)}

Physiognomy and floristic composition. This forest type consists of three stages of successional development corresponding to a late community (sensu Budowski, 1985; Capote \& al., 1988; Reyes \& Acosta, 2005). Differences 
Table 14. Characteristic combination of jocuma with guao (Sideroxylon foetidissimum subsp. foetidissimum with Comocladia dentata, 3 plots)

\begin{tabular}{|c|c|c|c|}
\hline Species & $\begin{array}{c}\text { Vertical } \\
\text { structure }\end{array}$ & $\begin{array}{c}\text { Abundance- } \\
\text { Coverage }\end{array}$ & Presence Degree \\
\hline \multicolumn{4}{|c|}{\begin{tabular}{|l} 
Canopy layer \\
\end{tabular}} \\
\hline Sideroxylon foetidissimum subsp. foetidissimum & $\mathrm{P}$ & 3 & $\mathrm{~V}$ \\
\hline Comocladia dentata & $\mathrm{D}$ & 2 & $\mathrm{~V}$ \\
\hline Bursera simaruba & $\mathrm{P}$ & 1 & $\mathrm{~V}$ \\
\hline Sideroxylon salicifolium & $\mathrm{C}$ & 1 & $\mathrm{~V}$ \\
\hline Ocotea coriacea & $\mathrm{C}$ & 1 & $\mathrm{~V}$ \\
\hline Exostema caribaeum & $\mathrm{C}$ & 1 & $\mathrm{~V}$ \\
\hline Cupania glabra & $\mathrm{C}$ & 1 & $\mathrm{~V}$ \\
\hline Adelia ricinella & $\mathrm{O}$ & 1 & $\mathrm{~V}$ \\
\hline Alvaradoa amorphoides & $\mathrm{O}$ & 1 & $\mathrm{~V}$ \\
\hline Exothea paniculata & $\mathrm{C}$ & 1 & IV \\
\hline \multicolumn{4}{|c|}{ Shrub layer } \\
\hline Eugenia sp. & - & 3 & $\mathrm{~V}$ \\
\hline Picramnia pentandra & - & 1 & $\mathrm{~V}$ \\
\hline Casearia hirsuta & - & 1 & $\mathrm{~V}$ \\
\hline Erythtroxylum havanense & - & 1 & $\mathrm{~V}$ \\
\hline E. rotundifolium & - & 1 & $\mathrm{~V}$ \\
\hline Varronia globosa & - & 1 & $\mathrm{~V}$ \\
\hline Capparis flexuosa & - & 1 & IV \\
\hline Coccoloba diversifolia & - & 1 & IV \\
\hline Erithalis fruticosa & - & 1 & IV \\
\hline Chrysophylum oliviforme & - & 1 & IV \\
\hline Guettarda sp. & - & 1 & IV \\
\hline Senna atomaria & - & 1 & IV \\
\hline Zanthoxylum fagara & - & 1 & IV \\
\hline \multicolumn{4}{|c|}{ Herbaceous layer } \\
\hline Desmodium incanum & - & 1 & V \\
\hline Zapoteca gracilis & - & 1 & V \\
\hline Scleria lithosperma & - & 1 & V \\
\hline Commelina elegans & - & 1 & $\mathrm{~V}$ \\
\hline Lasiacis divaricata & - & 1 & IV \\
\hline Selenicereus grandiflorus & - & 1 & IV \\
\hline Rivina humilis & - & 1 & IV \\
\hline Oeceoclades maculata & - & 1 & IV \\
\hline Agave sp. & - & 1 & IV \\
\hline Lantana camara & - & 1 & IV \\
\hline Urochloa humidicola & - & 1 & IV \\
\hline \multicolumn{4}{|c|}{ Lianas } \\
\hline Pisonia aculeata & - & 1 & V \\
\hline Smilax havanensis & - & 1 & $\mathrm{~V}$ \\
\hline Stigmaphyllon sagreanum & - & 1 & $\mathrm{~V}$ \\
\hline Gouania lupuloides & - & 1 & $\mathrm{~V}$ \\
\hline Serjania diversifolia & - & 1 & $\mathrm{~V}$ \\
\hline Chiococca alba & - & 1 & $\mathrm{~V}$ \\
\hline Turbina corymbosa & - & 1 & IV \\
\hline Tragia hexandra & - & 1 & IV \\
\hline \multicolumn{4}{|c|}{ Epiphytes } \\
\hline Tillandsia fasciculata & - & 1 & IV \\
\hline
\end{tabular}

Scattered species in the canopy layer: cedar (Cedrela odorata), carbonero, bijáguara (Colubrina ferruginosa), guamá (Lonchocarpus domingensis), penda, roble (Tabebuia sp.), mamoncillo (Melicoccus bijugatus), mahogany (Swietenia mahagoni), yaití, bone and cúrbana (Canella alba). 
are given by the degree of successional development and the ecological conditions, mainly exposure and position on the slope. Therefore, as they are located in the same area, they will be studied together, specifying only the differences. The canopy layer is from sparse to slightly sparse (70 to $90 \%$ ) and reaches between 9 and $12 \mathrm{~m}$ tall. Floristically, it is quite heterogeneous; a total of 41 species was found reaching this layer.

Oecotope characteristics. The studied site is hills between 20 and $100 \mathrm{~m}$ asl Most of it is located on the north side of the Coastal Terraces south of Sierra Maestra, so their secondary watershed and dells (that only run with considerable rainfall) are preferably north-northwest directed and to a lesser degree, northwest. The most frequent inclination is between $20-40^{\circ}$. The microrelief on the side is generally flat. The mean annual temperature is around $26^{\circ} \mathrm{C}$ and the average maximum is about $32^{\circ} \mathrm{C}$. Annual precipitation is near $800 \mathrm{~mm}$ (little rainy) and the mean annual evaporation is between 1700 and $1900 \mathrm{~mm}$ (Montenegro, 1991a, b, d). Therefore, it is considered a tropical climate with $4 \mathrm{bTh}$ subtype dry winter, with 5 to 6 months with little rain (semidry).

From the geological point of view, these hills are composed by marls from La Cruz formation (Comisión Cubano - Húngara, 1976). Soils are brown (with carbonate), and they are from shallow to very shallow. They even react with saliva. It is usually clay loam, sandy clay or sandy; stony in greater or lesser extent, with small and medium stones. Therefore, in general, the edatope is considered as dry (1) and little fertile (A), and the potential production capacity is inferred as bad (IV). The typology classification is considered A $1_{x}, 4 b T h_{b}$, IV, S.s., C.w.

Regarding the withered leaves, the L layer reaches about $2 \mathrm{~cm}$. The $\mathrm{F}$ layer is generally absent, except for areas with higher earthworm activity and the $\mathrm{H}$ is missing. This activity (which is higher in the more advanced successional stages) is very important here, because it incorporates organic matter into the soil. They form a mixed layer of 1 to $1.5 \mathrm{~cm}$ of soil and half-decomposed withered leaves, which influences the ecosystem nutrients cycle. Due to this rapid decomposition of fallen leaves and the total absence of root mat, the fermentation process can be considered as quick (Herrera \& Rodríguez, 1988).

The three subtypes (successional stages) are:

Cuyá with cúrbana and guatapaná, Cuyá with cúrbana and black ebony, Cuyá with cúrbana and lirio santana. Special features of the subtypes.
Cuyá with cúrbana and guatapaná (Sideroxylon salicifolium with Canella winterana and Acacia macracantha; Table 15)

This type of forest is the least advanced transitional successional stage. Here, frijolillo and guatapaná still play an important role in the canopy layer, which is slightly sparse. The cover of guairaje and cuyá is still very low. In the group of constant species, only guatapaná is within the main species group. Frijolillo, cuyá, cúrbana and almácigo are subdominants. In the shrub layer, whose coverage is from medium to high $(30-70 \%)$, only guairaje is considered as main species, the others are subdominants. The same happens in the herbaceous layer (it is from low to high, 10-90\%).

Usually, in this type of forest, soils have a higher degree of development and may be considered as shallow. They preferentially occupy the bottom of the slope (lower basin) and although they are usually steep (30-45) are directed towards the north (NE-NW). Therefore, the humidity here is more favorable than in other types of forest in this series (dry with a tendency to fresh).

The differential combination has cabo de hacha (Trichilia hirta) as a main species and jocuma and uvita (Cordia alba) as subdominants. The rest of the species are found in Table 15.

\section{Cuyá with cúrbana and black ebony (Sideroxylon salicifolium with Canella winterana and Diospyrus grisebachii; Table 16)}

It is found in the lower slopes of the entire community, as its inclination only occasionally exceeds 20 degrees. Although the position on the slope is variable, it is most commonly found in the upper part thereof; then, the relative height is usually greater than $20 \mathrm{~m}$. The exposure is to the north (NE-NW). Here, the earthworm activity described above is common. This type of forest is a more advanced successional stage than the above (late secondary community). In the canopy layer, cuyá is the main species and cúrbana, guatapaná, frijolillo, almácigo and lirio santana are the subdominants ones. The main species from the shrub layer is guairaje (Eugenia axillaris), with a high cover (50-80\%). From the herbaceous layer, cuaba de ingenio (media occasionally high covers, 40-70\%) was the main specie. Here, the number of tree seedlings is higher than in the previous type of forest. In the differential combination, the subdominants species from the canopy layer are: black ebony and negracuba. Other subdominant species from the shrub and herbaceous layers and liana synusiae are shown in Table 16. 
Table 15. Cuyá with cúrbana and guatapaná

(Sideroxylon salicifolium with Canella winterana and Acacia macracantha, 6 plots)

\begin{tabular}{|c|c|c|c|}
\hline Species & $\begin{array}{l}\text { Vertical } \\
\text { structure }\end{array}$ & $\begin{array}{l}\text { Abundance- } \\
\text { Coverage }\end{array}$ & $\begin{array}{c}\text { Presence } \\
\text { Degree }\end{array}$ \\
\hline \multicolumn{4}{|c|}{ Canopy layer } \\
\hline Acacia macracantha & $\mathrm{D}$ & 2 & $\mathrm{~V}$ \\
\hline Senna atomaria & $\mathrm{D}$ & 1 & $\mathrm{~V}$ \\
\hline Sideroxylon salicifolium & $\mathrm{C}$ & 1 & $\mathrm{~V}$ \\
\hline Canella winterana & $\mathrm{C}$ & 1 & $\mathrm{~V}$ \\
\hline Bursera simaruba & $\mathrm{C}$ & 1 & $\mathrm{~V}$ \\
\hline Lonchocarpus domingensis & I & 1 & III \\
\hline \multicolumn{4}{|c|}{ Shrub layer } \\
\hline Eugenia axillaris & - & 2 & $\mathrm{~V}$ \\
\hline Coccothrinax fragans & - & 1 & $\mathrm{~V}$ \\
\hline Comocladia dentata & - & 1 & $\mathrm{~V}$ \\
\hline Bourreria virgata & - & 1 & $\mathrm{~V}$ \\
\hline Randia aculeata & - & 1 & IV \\
\hline \multicolumn{4}{|c|}{ Herbaceous laye } \\
\hline Scleria lithosperma & - & 1 & $\mathrm{~V}$ \\
\hline Lasiacis divaricata & - & 1 & $\mathrm{~V}$ \\
\hline Paspalum breve & - & 1 & $\mathrm{~V}$ \\
\hline Zapoteca gracilis & - & 1 & IV \\
\hline Lantana camara & - & 1 & III \\
\hline Trema micrantha & - & 1 & III \\
\hline \multicolumn{4}{|c|}{ Lianas } \\
\hline Stigmaphyllon sagreanum & - & 1 & $\mathrm{~V}$ \\
\hline Chiococca alba & - & 1 & $\mathrm{~V}$ \\
\hline Smilax havanensis & - & 1 & IV \\
\hline Cissampelos pareira & - & 1 & III \\
\hline \multicolumn{4}{|c|}{ Differential combination from cuyá with cúrbana and guatapaná } \\
\hline \multicolumn{4}{|c|}{ Canopy layer } \\
\hline Trichilia hirta & $\mathrm{D}$ & 2 & $\mathrm{~V}$ \\
\hline Sideroxylon foetidissimum subsp. foetidissimum & $\mathrm{C}$ & 1 & $\mathrm{~V}$ \\
\hline Cordia alba & $\mathrm{C}$ & 1 & $\mathrm{~V}$ \\
\hline \multicolumn{4}{|c|}{ Shrub layer } \\
\hline Ehretia tinifolia & - & 1 & $\mathrm{~V}$ \\
\hline Turnera ulmifolia & - & 1 & $\mathrm{~V}$ \\
\hline \multicolumn{4}{|c|}{ Herbaceous layer } \\
\hline Erythroxylum havanense & - & 1 & $\mathrm{~V}$ \\
\hline Chrysophyllum oliviforme & - & 1 & $\mathrm{~V}$ \\
\hline Casearia hirsuta & - & 1 & $\mathrm{~V}$ \\
\hline Urochloa humidicola & - & 1 & $\mathrm{~V}$ \\
\hline Heliotropium indicum & - & 1 & IV \\
\hline Commelina erecta & - & 1 & IV \\
\hline Desmanthus virgatus & - & 1 & IV \\
\hline \multicolumn{4}{|c|}{ Lianas } \\
\hline Gouania lupuloides & - & 1 & $\mathrm{~V}$ \\
\hline Serjania diversifolia & - & 1 & $\mathrm{~V}$ \\
\hline Salacia nipensis & - & 1 & IV \\
\hline \multicolumn{4}{|c|}{ Epiphytes } \\
\hline Tillandsia recurvata & - & 1 & IV \\
\hline
\end{tabular}

Scattered species in the canopy layer: carbonero, jia blanca (Adelia ricinella), guara (Cupania glabra), Citharexylum ternatum, guaguasí (Zuelania guidonia), sigua, black ebony (Diospyrus grisebachii), guamá (Lonchocarpus longipes) and brasil (Caesalpinia vesicaria). 
Table 16. Cuyá with cúrbana and black ebony

(Sideroxylum salicifolium with Canella winterana and Diospyrus grisebachii, 8 plots)

\begin{tabular}{|c|c|c|c|}
\hline Species & $\begin{array}{c}\text { Vertical } \\
\text { structure }\end{array}$ & $\begin{array}{l}\text { Abundance- } \\
\text { Coverage }\end{array}$ & Presence Degree \\
\hline \multicolumn{4}{|c|}{ Canopy layer } \\
\hline Sideroxylon salicifolium & $\mathrm{D}$ & 3 & $\mathrm{~V}$ \\
\hline Canella winterana & $\mathrm{C}$ & 1 & $\mathrm{~V}$ \\
\hline Acacia macracantha & $\mathrm{C}$ & 1 & $\mathrm{~V}$ \\
\hline Senna atomaria & $\mathrm{C}$ & 1 & $\mathrm{~V}$ \\
\hline Bursera simaruba & $\mathrm{C}$ & 1 & $\mathrm{~V}$ \\
\hline Exostema caribaeum & I & 1 & $\mathrm{~V}$ \\
\hline Sideroxylon foetidissimum subsp. foetidissimum & $\mathrm{C}$ & 1 & IV \\
\hline Colubrina elliptica & $\mathrm{C}$ & 1 & IV \\
\hline Bourreria virgata & $\mathrm{I}$ & 1 & IV \\
\hline \multicolumn{4}{|c|}{ Shrub layer } \\
\hline Eugenia axillaris & - & 3 & $\mathrm{~V}$ \\
\hline Comocladia dentata & - & 1 & $\mathrm{~V}$ \\
\hline Randia aculeata & - & 1 & $\mathrm{~V}$ \\
\hline Lantana montevidensis & - & 1 & IV \\
\hline Zanthoxylum fagara & - & 1 & IV \\
\hline \multicolumn{4}{|c|}{ Herbaceous layer } \\
\hline Croton lucidus & - & 2 & $\mathrm{~V}$ \\
\hline Coccothrinax fragans & - & 1 & $\mathrm{~V}$ \\
\hline Lasiacis divaricata & - & 1 & IV \\
\hline Paspalum breve & - & 1 & IV \\
\hline Scleria lithosperma & - & 2 & IV \\
\hline Zapoteca gracilis & - & 1 & III \\
\hline Varronia globosa subsp. humilis & - & 1 & III \\
\hline Morinda royoc & - & 1 & III \\
\hline Erytrhroxylum rotundifolium & - & 1 & III \\
\hline \multicolumn{4}{|l|}{ 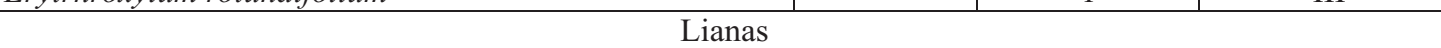 } \\
\hline Tragia hexandra & - & 1 & $\mathrm{~V}$ \\
\hline Chiococca alba & - & 1 & $\mathrm{~V}$ \\
\hline Smilax havanensis & - & 1 & $\mathrm{~V}$ \\
\hline Stigmaphyllon sagreanum & - & 1 & IV \\
\hline Salacia nipensis & - & 1 & IV \\
\hline Passiflora suberosa & - & 1 & IV \\
\hline Gouania lupuloides & - & 1 & III \\
\hline Distictis rhynchocarpa & - & 1 & III \\
\hline Triopteris rigida & - & 1 & III \\
\hline \multicolumn{4}{|c|}{ Differential combination from cuyá with cúrbana duldck ebony } \\
\hline \multicolumn{4}{|c|}{ Canopy layer } \\
\hline Diospyrus grisebachii & I & 1 & $\mathrm{~V}$ \\
\hline Thouinia patentinervis & I & 1 & IV \\
\hline \multicolumn{4}{|c|}{ Shrub layer } \\
\hline Trema micrantha & - & 1 & IV \\
\hline Erithalis fruticosa & - & 1 & IV \\
\hline Lantana camara & - & 1 & IV \\
\hline \multicolumn{4}{|c|}{ Herbaceous layer } \\
\hline Spermacoce laevis & - & 1 & IV \\
\hline Bourreria setoso-hispida & - & 1 & IV \\
\hline Varronia lineata & - & 1 & IV \\
\hline Euphorbia heterophylla & - & 1 & IV \\
\hline \multicolumn{4}{|c|}{ Lianas } \\
\hline Cissus verticillata & - & 1 & IV \\
\hline
\end{tabular}

Scattered species in the canopy layer: cuabilla (Amyris elemifera), guaguasí, roble prieto, guamá de costa (Lonchocarpus longipes), guamá (Lonchocarpus domingensis), guara, sigua, Citharexylum ternatum, brasil, jia blanca and raspalengua (Casearia hirsuta). 
Cuyá with cúrbana and lirio santana (Sideroxylon salicifolium with Canella winterana and Exostema caribaeum; Table 17)

It is generally observed in exposures to the west ( $\mathrm{N}$ to SSW), on slopes of $20-40^{\circ}$ and generally, in the mid to upper hillside, so the relative height is greater than $20 \mathrm{~m}$. The microrelief is often slightly wavy.

This forest is also a late secondary community; the main tree pioneers (guatapaná and frijolillo) generally have diminished vitality and poor or very poor regeneration. The dominant species in the canopy layer are cuyá and cúrbana and the above mentioned species and the almácigo are also subdominant.
In the shrub layer (high cover, 50-80\%) guairaje (Eugenia axillaris) is the main specie; while in the herbaceous (media to heig covers, $40-70 \%$ ) it is cortadera (Scleria lithosperma). The other subdominant species in both layers, as well as lianas are shown in Table 17. The proportion of tree seedlings is high in these strata, which also confirmed how advanced the successional stage is.

The soil is very shallow, sometimes gravelly and with some stones on the surface. Due to its inclination, position on the slope and exposure, it can be considered as a dry (1) and little fertile (A) oecotope.

Table 17. Cuyá with cúrbana and lirio santana

(Sideroxylon salicifolium with Canella winterana and Exostema caribaeum, 6 plots)

\begin{tabular}{|c|c|c|c|}
\hline Species & $\begin{array}{c}\text { Vertical } \\
\text { structure }\end{array}$ & $\begin{array}{c}\text { Abundance- } \\
\text { Coverage }\end{array}$ & Presence Degree \\
\hline \multicolumn{4}{|c|}{ Canopy layer } \\
\hline Sideroxylon salicifolium & $\mathrm{D}$ & 2 & $\mathrm{~V}$ \\
\hline Canella winterana & $\mathrm{D}$ & 1 & $\mathrm{~V}$ \\
\hline Bursera simaruba & $\mathrm{C}$ & 1 & $\mathrm{~V}$ \\
\hline Acacia macracantha & $\mathrm{I}$ & 1 & $\mathrm{~V}$ \\
\hline Senna atomaria & $\mathrm{I}$ & 1 & $\mathrm{~V}$ \\
\hline \multicolumn{4}{|c|}{ Shrub layer } \\
\hline Eugenia axillaris & - & 2 & $\mathrm{~V}$ \\
\hline Randia aculeata & - & 1 & $\mathrm{~V}$ \\
\hline Lantana montevidensis & - & 1 & $\mathrm{~V}$ \\
\hline Amyris elemifera & - & 1 & $\mathrm{~V}$ \\
\hline Caesalpinia vesicaria & - & 2 & III \\
\hline Comocladia dentata & - & 1 & III \\
\hline \multicolumn{4}{|c|}{ Herbaceous layer } \\
\hline Scleria lithosperma & - & 2 & $\mathrm{~V}$ \\
\hline Coccothrinax fragans & - & 1 & $\mathrm{~V}$ \\
\hline Croton lucidus & - & 1 & $\mathrm{~V}$ \\
\hline Zapoteca gracilis & - & 1 & $\mathrm{~V}$ \\
\hline Zanthoxylum fagara & - & 1 & $\mathrm{~V}$ \\
\hline Paspalum breve & - & 1 & $\mathrm{~V}$ \\
\hline Simarouba laevis & - & 1 & $\mathrm{~V}$ \\
\hline Lasiacis divaricata & - & 1 & IV \\
\hline Oplonia tetrasticha & - & 1 & III \\
\hline \multicolumn{4}{|c|}{ Lianas } \\
\hline Tragia hexandra & - & 1 & $\mathrm{~V}$ \\
\hline Stigmaphyllon sagreanum & - & 1 & $\mathrm{~V}$ \\
\hline Chiococca alba & - & 1 & $\mathrm{~V}$ \\
\hline Smilax havanensis & - & 1 & $\mathrm{~V}$ \\
\hline Tragia volubilis & - & 1 & IV \\
\hline Salacia nipensis & - & 1 & III \\
\hline Distictis rhynchocarpa & - & 1 & III \\
\hline \multicolumn{4}{|c|}{ Differential combination from cuyá with cúrbana and lirio santana } \\
\hline Exostema caribaeum & $\mathrm{I}$ & 1 & $\mathrm{~V}$ \\
\hline Colubrina elliptica & $\mathrm{C}$ & 1 & IV \\
\hline Passiflora suberosa & - & 1 & IV \\
\hline
\end{tabular}

Scattered species in the canopy layer: negracuba, raspalengua, black ebony, jocuma, roble prieto, sigua, guara, Citharexylum ternatum and cuaba prieta. 
Terms for forest management. As these subtypes are successional stages, enrichment with valuable species from the forestry point of view should be achieved in silvicultural treatment, mainly in the less advanced stages. Some of these species are: cedar, bijáguara, roble (Tabebuia sp.), mahogany, bone, cuyá, jocuma, brasil, sabicú, dagame and baría.

\section{Guatapaná with frijolillo and cafecillo (Acacia macracantha with Senna atomaria and Bourreria virgata; Table 18)}

Physiognomy and floristic composition. Low secondary forest showing dominance of thorny legumes. It is an early community (homeostasis I) after total or near total destruction of the previous vegetation. The canopy layer is low and fairly open sparse (50 to $60 \%)$; its height is about 7 to 8 $\mathrm{m}$. The main species at the group of constant species are guatapaná and frijolillo; while the subdominant are ipil ipil and uvita. The species from the other strata and synusiaes, including the group of accompanying species and of differential combination are shown in Table 18. The difference with the shrub layer is often unclear.

Oecotope characteristics. It can be seen below $150 \mathrm{~m}$ a.s.1, showing a flat microrelief; exposures are varied, mainly to the south. The slope varies between $15-25^{\circ}$. The mean annual temperature ranges from $24-26^{\circ} \mathrm{C}$. The mean annual relative humidity is 75 to $80 \%$ and evaporation is 1700 to $1900 \mathrm{~mm}$ (Montenegro, 1991a, b, c). It rains about $1000 \mathrm{~mm}$, with little rainy season from November to April and a rainy from May to October. It is therefore considered a tropical climate with dry winter, 4bTh subtype, with 5-6 dry months (semi-dry). It is also heavily influenced by the salt spray sea breezes. It occurs on soils derived from volcanogenic sedimentary rocks and limestones. The soil is fersiallitic reddish brown (Renda, 1989), very shallow and highly eroded. Therefore, it is considered as very dry $(0)$ and little fertile (A). The potential production capacity is inferred as very bad (V) and the typology classification is A0, $4 \mathrm{bTh} \mathrm{b}_{\mathrm{c}-\mathrm{c}}$, V, A.m., S.a., Bv.

Distribution. It was studied in the southern part of Sierra del Turquino, near the community of Las Brujas (Santiago de Cuba Province).

Terms for forest management. As they are an early community (homeostasis I) after the destruction of the original forest, it has very little diversity of tree species in the shrub and herbaceous layers. That is why, an enrichment with species adapted to the oecotope is advised; such as: jatía, baría, carbonero, majaguilla, almácigo, sigua, cuyá, yarúa and macaguey (toad).

\section{Guatapaná with frijolillo and raspalengua (Acacia macracantha with Senna atomaria and Casearia hirsuta; Table 19)}

Physiognomy and floristic composition. This forest type is an early community (homeostasis I), i.e. the relative equilibrium stage taking place after the first phase fiera (Reyes $\& a l ., 2004 b)$. The canopy layer reaches between 6 and $9 \mathrm{~m}$ and is slightly sparse (80-90\%). The main species are guatapana and frijolillo, especially the first which determine the physiognomy of the ecosystem. They form a continuous and clear canopy that allows the passage of light. Uvita is the subdominant species. The shrub (20-60\%) and herbaceous $(30-70 \%)$ layers have a covers from medium to high, exceptionally less. They are mainly composed by woody micro and nanophanerophytes, some herbaceous and lianas, which can be found in Table 19.

Since guatapana is the main contributor to the withered leaves, and it has leptophyll leaflets, the L layer is generally less than a centimeter and often scattered. The F layer is barely noticeable and the $\mathrm{H}$ only contains (sometimes) remains on the ground. For this and the absence of root mat, fermentation can be considered quick (Herrera \& Rodriguez, 1988).

Oecotope characteristics. The studied areas are hills between 20 and $100 \mathrm{~m}$ asl Their secondary watershed and dells (which only run with considerable rainfall) are preferably north-west directed and to a lesser degree, northwest. The most frequent inclination is between 20 and 40 degrees, the microrelief on the side is generally flat. It prefers sunny exposures, especially to the southwest. The relative height is less than $20 \mathrm{~m}$ in general. The mean annual temperature is around $26^{\circ} \mathrm{C}$ and the mean maximum is about $32^{\circ} \mathrm{C}$. The annual precipitation is near $800 \mathrm{~mm}$ (little rain) and the mean annual evaporation is between 1700 and $1900 \mathrm{~mm}$ (Montenegro, 1991a, b, c); so it can be considered a tropical climate with two dry periods, 5aTh subtype, extremely dry tropical bixeric.

Geologically, these hills are composed by Pliocene marl from La Cruz formation. Soils are brown (carbonate), from shallow to very shallow and even react with saliva. They are commonly sandy loam and sometimes locally gravelly. It is often rocky with small and midstones on the top of the profile. The laminar erosion is variable; in some places it is weak, in other is strong though. Regarding the edatope moisture, it can be considered as dry (1) and little fertile (A). The typology classification is as follows $A_{x} 1,5 a T h b$, IV, A.m., S.a., C.h. 
Table 18. Characteristic combination of guatapaná with frijolillo and cafecillo (Acacia macracantha with Senna atomaria and Bourreria virgata, 4 plots)

\begin{tabular}{|c|c|c|c|}
\hline Species & $\begin{array}{l}\text { Vertical } \\
\text { structure }\end{array}$ & $\begin{array}{c}\text { Abundance- } \\
\text { Coverage }\end{array}$ & Presence Degree \\
\hline \multicolumn{4}{|c|}{ Canopy layer } \\
\hline Acacia macracantha & $\mathrm{D}$ & 3 & $\mathrm{~V}$ \\
\hline Senna atomaria & $\mathrm{D}$ & 2 & $\mathrm{~V}$ \\
\hline Cordia alba & $\mathrm{C}$ & 1 & $\mathrm{~V}$ \\
\hline \multicolumn{4}{|c|}{ Herbaceous layer } \\
\hline Bothrichloa pertusa & - & 2 & $\mathrm{~V}$ \\
\hline Zapoteca gracilis & - & 1 & $\mathrm{~V}$ \\
\hline Commelina diffusa & - & 1 & $\mathrm{~V}$ \\
\hline Spermacoce laevis & - & 1 & $\mathrm{~V}$ \\
\hline Malpighia cnide & - & 1 & IV \\
\hline Sida rhombifolia & - & 1 & IV \\
\hline Malvastrum corchorifolium & - & 1 & III \\
\hline Urochloa humidicola & - & 1 & III \\
\hline Helicteres $\mathrm{sp}$. & - & 1 & III \\
\hline Coccothrinax fragans & - & 1 & III \\
\hline Desmanthus virgatus & - & 1 & III \\
\hline Zanthoxylum fagara & - & 1 & III \\
\hline Corchorus sp. & - & 1 & III \\
\hline Bourreria sp. & - & 1 & III \\
\hline Wissadula periplocifolia & - & 1 & III \\
\hline Sida acuta & - & 1 & III \\
\hline Desmodium sp. & - & 1 & III \\
\hline \multicolumn{4}{|c|}{ Lianas } \\
\hline Stigmaphyllon sagreanum & - & 1 & $\mathrm{~V}$ \\
\hline Dalechampia scandens & - & 1 & $\mathrm{~V}$ \\
\hline Cissus trifoliata & - & 1 & $\mathrm{~V}$ \\
\hline Chiococca alba & - & 1 & IV \\
\hline Tournefortia volubilis & - & 1 & IV \\
\hline Triopteris rigida & - & 1 & IV \\
\hline Centrosema virginianum & - & 1 & III \\
\hline Commicarpus scandens & - & 1 & III \\
\hline Galactia sp. & - & 1 & III \\
\hline Ipomoea sp. & - & 1 & III \\
\hline \multicolumn{4}{|c|}{ Epiphytes } \\
\hline Tillandsia recurvata & - & 1 & IV \\
\hline \multicolumn{4}{|c|}{ Differential combination from guatapaná with frijolillo and cafecillo } \\
\hline Bourreria virgata & $\mathrm{I}$ & 2 & $\mathrm{~V}$ \\
\hline Leucaena leucocephala & $\mathrm{C}$ & 1 & $\mathrm{~V}$ \\
\hline Varronia globosa subsp. humilis & - & 3 & $\mathrm{~V}$ \\
\hline Wissadula amplissima & - & 1 & $\mathrm{~V}$ \\
\hline Lantana reticulata & - & 1 & $\mathrm{~V}$ \\
\hline Phyllostyllon brasiliensis & - & 1 & IV \\
\hline Adelia ricinella & - & 1 & IV \\
\hline Randia aculeata & - & 1 & IV \\
\hline
\end{tabular}

Scattered species in the canopy layer: Casearia sp., cuaba prieta. 
Table 19. Guatapaná with frijolillo and raspalengua (Acacia macracantha with Senna atomaria and Casearia hirsuta) in the marls from the South Coastal Terraces of Sierra Maestra (6 plots).

\begin{tabular}{|c|c|c|c|}
\hline Species & $\begin{array}{c}\text { Vertical } \\
\text { structure }\end{array}$ & $\begin{array}{c}\text { Abundance- } \\
\text { Coverage }\end{array}$ & $\begin{array}{c}\text { Presence } \\
\text { Degree }\end{array}$ \\
\hline \multicolumn{4}{|c|}{ Canopy layer } \\
\hline Acacia macracantha & $\mathrm{D}$ & 4 & $\mathrm{~V}$ \\
\hline Senna atomaria & $\mathrm{D}$ & 2 & $\mathrm{~V}$ \\
\hline Cordia alba & $\mathrm{C}$ & 1 & $\mathrm{~V}$ \\
\hline Ehretia tinifolia & $\mathrm{C}$ & 1 & IV \\
\hline \multicolumn{4}{|c|}{ Shrub layer } \\
\hline Coccothrinax fragans & - & 1 & IV \\
\hline Lantana camara & - & 1 & IV \\
\hline \multicolumn{4}{|c|}{ Herbaceous layer } \\
\hline Waltheria indica & - & 1 & $\mathrm{~V}$ \\
\hline Zapoteca gracilis & - & 1 & $\mathrm{~V}$ \\
\hline Lantana montevidensis & - & 1 & V \\
\hline Wissadula periplocifolia & - & 1 & $\mathrm{~V}$ \\
\hline Melochia nodiflora & - & 1 & $\mathrm{~V}$ \\
\hline Euphorbia heterophylla & - & 1 & $\mathrm{~V}$ \\
\hline Spermacoce laevis & - & 1 & $\mathrm{~V}$ \\
\hline Bothriochloa pertusa & - & 1 & $\mathrm{~V}$ \\
\hline Urochloa humidicola & - & 1 & $\mathrm{~V}$ \\
\hline Scleria lithosperma & - & 1 & $\mathrm{~V}$ \\
\hline Lasiacis divaricata & - & 1 & $\mathrm{~V}$ \\
\hline Dicliptera vahliana & - & 1 & IV \\
\hline Jatropha gossipifolia & - & 1 & IV \\
\hline Cenchrus ciliaris & - & 2 & IV \\
\hline Commelina erecta & - & 1 & IV \\
\hline Varronia globosa subsp. humilis & - & 1 & III \\
\hline Erythroxylum havanense & - & 1 & III \\
\hline Hibiscus brasiliensis & - & 1 & III \\
\hline Comocladia dentata & - & 1 & III \\
\hline Chromolaena odorata & - & 1 & III \\
\hline Pavonia spinifex & - & 1 & III \\
\hline \multicolumn{4}{|c|}{ Lianas } \\
\hline Passiflora suberosa & - & 1 & $\mathrm{~V}$ \\
\hline Stigmaphyllon sagreanum & - & 1 & $\mathrm{~V}$ \\
\hline Tournefortia volubilis & - & 1 & $\mathrm{~V}$ \\
\hline Centrosema virginianum & - & 1 & $\mathrm{~V}$ \\
\hline Desmanthus virgatus & - & 1 & $\mathrm{~V}$ \\
\hline Smilax havanensis & - & 1 & $\mathrm{~V}$ \\
\hline Triopteris rigida & - & 1 & $\mathrm{~V}$ \\
\hline Passiflora foetida & - & 1 & IV \\
\hline Salacia nipensis & - & 1 & IV \\
\hline Merrenia bisecta & - & 1 & III \\
\hline Chiococca alba & - & 1 & III \\
\hline Serjania diversifolia & - & 1 & III \\
\hline \multicolumn{4}{|c|}{ Epiphytes } \\
\hline Tillandsia recurvata & - & 1 & IV \\
\hline Tillandsia fasciculata & - & 1 & III \\
\hline \multicolumn{4}{|c|}{ Differential combination from guatapaná with frijolillo and raspalengua } \\
\hline Casearia hirsuta & - & 1 & $\mathrm{~V}$ \\
\hline Turnera ulmifolia & - & 1 & $\mathrm{~V}$ \\
\hline Paspalum breve & - & 1 & V \\
\hline Echites umbellata & - & 1 & $\mathrm{~V}$ \\
\hline Plumbago scandens & - & 1 & $\mathrm{~V}$ \\
\hline
\end{tabular}

Scattered species in the canopy layer: cuyá, jubaban (Trichilia hirta), brasil, cúrbana, jía blanca, jocuma, penda, aguedita dulce, carbonero, agalla de costa and cafecillo. 
Distribution. It presents its greatest extent in the northeastern part of the marly hills from the South Coastal Terraces of Sierra Maestra.

Terms for forest management. As it is a community similar to the previous forest (homeostasis I), it has very little diversity of tree species in the shrub and herbaceous layers. That is why, enrichment with species adapted to the oecotope is advised; such as: jatía, baría, carbonero, majaguilla, almácigo, sigua, cuyá, yarúa and macaguey (toad).

\section{Yaya with almácigo (Oxandra lanceolada with Bursera simaruba; Table 20)}

Physiognomy and floristic composition. Although this vegetation type (semideciduous mesophyll forest) has been exploited for livestock development, the analyzed area has a high degree of naturalness. The canopy layer has coverage from sparse to slightly sparse (50-90\%) and a height between 7 and $15 \mathrm{~m}$. In the group of constant species, almácigo and yaya (Oxandra lanceolada) are the main species; while baría and guamá candelón (Piscidia piscipula) are the subdominant. These species from the shrub and herbaceous layers, as well as the synusiaes of lianas and epiphytes are found in Table 20.

In the group of accompanying species, jocuma, guárano (Cupania americana), guásima, jobo (Spondias mombin), jatía and sabicú (Lysiloma sabicu) are subdominant species. Bone, yaití, guara, guaguasí, tengue (Poeppigia procera), royal palm (Roystonea regia), ramon horse (Trophis racemosa), cuyá and majaguilla are aggregated species. Plants from other layer are shown in Table 20.

The species from the shrub layer with a cover from medium to high (40-90\%) and the herbaceous layer with medium (30-50\%) are found in Table 20. The composition of biological types is as follows: $40.5 \%$ of the species are trees, $24.3 \%$ are shrubs, $13.5 \%$ form the herbaceous layer, $2.7 \%$ are ferns, $16.2 \%$ are lianas and the $4.1 \%$, epiphytes.

Oecotope characteristics. The microrelief is generally flat. It locally shows rocky outcrops on the surface. The slope is also very variable, ranging between 20 and 40 degrees. The exposure has two main trends: one to the east and the other to south. The altitude varies between 120 and $200 \mathrm{~m}$ asl The mean annual rainfall in this area is 1000 to $1200 \mathrm{~mm}$ per year, i.e. moderately rainy. There are two distinct periods: the dry season, from November to April (between 300 and $400 \mathrm{~mm}$ ) and the rainy season, from May to October (800 and $1000 \mathrm{~mm}$ ) (Montenegro, 1991a). It is consi- dered a tropical climate with dry winter, subtype 4bTh, with 5-6 dry months (semi-dry).

The most important soil is the reddish brown fersiallitic; its depth varies from very shallow to moderately deep. It drains well, both internal and external. Therefore, the edatope is considered as dry (1) and from little to moderately fertile (B). Withered leaves are unevenly distributed, the $\mathrm{L}$ layer ranges between 1.5 and $3 \mathrm{~cm}$, occasionally more; in isolated nanodepressions can reach up to 15 $\mathrm{cm}$. F and $\mathrm{H}$ layers are almost imperceptible, and only the last is observed, mixed with the horizon A. In turn, the potential productive capacity is considered from bad (IV) to regular (III). The typology classification is as follows B1, 4bTh, III-IV, O.1., B.s.

Distribution. This forest is a typical semideciduous mesophyll forest, which had a large area in the flat and premountain areas. It was studied on the southern slope of the mountain range of Sierra Maestra. Nowadays, the most extensive relict is located near the mouth of Turquino river.

Terms for forest management. Almost all areas from the mesophyll semideciduous forest have been destroyed for agriculture and livestock purposes, so it is necessary to preserve these relics, which are relatively rich in tree species.

\section{Jubaban with guásima (Trichilia hirta with Guazuma ulmifolia; Table 21)}

Physiognomy and floristic composition. This secondary forest is a late secondary community (fiera II and homeostasis II) from the successional series that takes place in the mesophyll semideciduous forest; the most advanced one has more species in all strata. The canopy layer is irregular in height and varies from 7 to $12 \mathrm{~m}$. Cover is from sparse to dense $(60-100 \%)$. Among the group of constant species, guásima (the most abundant) and frijolillo are the main species. The subdominants are jubaban, baría, jobo, majaguilla, negracuba and yuraguana (Coccothrinax gundlachii). In the group of accompanying species, almácigo is subdominant and aguedita (Celtis trinervia) aggregated. The species in the shrub layer with a covers from medium to high $(40-80 \%)$ are in Table 21 , as well as the species with medium coverage (30-50\%) from the herbaceous layer and lianas.

Oecotope characteristics. It occurs between 40 and $100 \mathrm{~m}$ asl, with an inclination of $20-37^{\circ}$ and in various exposures. The microrelief is relatively flat. The mean annual temperature ranges from 24 to 
Table 20. Yaya with almácigo

(Oxandra lanceolada with Bursera simaruba, 9 plots)

\begin{tabular}{|c|c|c|c|}
\hline Species & $\begin{array}{l}\text { Vertical } \\
\text { structure }\end{array}$ & $\begin{array}{l}\text { Abundance- } \\
\text { Coverage }\end{array}$ & Presence Degree \\
\hline \multicolumn{4}{|c|}{ Canopy layer } \\
\hline Bursera simaruba & $\mathrm{D}$ & 2 & $\mathrm{~V}$ \\
\hline Oxandra lanceolata & $\mathrm{D}$ & 2 & $\mathrm{~V}$ \\
\hline Cordia gerascanthus & $\mathrm{C}$ & 1 & V \\
\hline Piscidia piscipula & $\mathrm{C}$ & 1 & V \\
\hline Sideroxylon foetidissimum subsp. foetidissimum & $\mathrm{C}$ & 1 & IV \\
\hline Cupania americana & $\mathrm{C}$ & 1 & IV \\
\hline Guazuma ulmifolia & $\mathrm{C}$ & 1 & IV \\
\hline Spondias mombin & $\mathrm{C}$ & 1 & IV \\
\hline Phyllostylon brasiliensis & $\mathrm{I}$ & 1 & IV \\
\hline Lysyloma sabicu & I & 1 & IV \\
\hline Drypetes alba & $\mathrm{C}$ & 1 & III \\
\hline Gymnanthes lucida & $\mathrm{I}$ & 1 & III \\
\hline Cupania glabra var. glabra & $\mathrm{C}$ & 1 & III \\
\hline Zuelania guidonia & $\mathrm{C}$ & 1 & III \\
\hline Roystonea regia & $\mathrm{C}$ & 1 & III \\
\hline Trophis racemosa & $\mathrm{C}$ & 1 & III \\
\hline Sideroxylon salicifolium & $\mathrm{C}$ & 1 & III \\
\hline Poeppigia procera & $\mathrm{I}$ & 1 & III \\
\hline Carpodiptera cubensis & I & 1 & III \\
\hline \multicolumn{4}{|c|}{ Shrub layer } \\
\hline Erythroxylum havanense & - & 1 & $\mathrm{~V}$ \\
\hline Picramnia pentandra & - & 1 & $\mathrm{~V}$ \\
\hline Coccothrinax gundlachii & - & 1 & IV \\
\hline Trichilia hirta & - & 1 & IV \\
\hline Capparis flexuosa & - & 1 & III \\
\hline Casearia sylvestris var. myricoides & - & 1 & III \\
\hline \multicolumn{4}{|c|}{ Herbaceous layer } \\
\hline Olyra latifolia & - & 1 & $\mathrm{~V}$ \\
\hline Oeceoclades maculata & - & 1 & IV \\
\hline Urochloa humidicola & - & 1 & III \\
\hline Zapoteca gracilis & - & 1 & III \\
\hline Rivina humilis & - & 1 & III \\
\hline \multicolumn{4}{|c|}{ Lianas } \\
\hline Serjania diversifolia & - & 1 & $\mathrm{~V}$ \\
\hline Gouania lupuloides var lupuloides & - & 1 & $\mathrm{~V}$ \\
\hline Pisonia aculeata & - & 1 & $\mathrm{~V}$ \\
\hline Stigmaphyllon sagreanum & - & 1 & $\mathrm{~V}$ \\
\hline \multicolumn{4}{|c|}{ Epiphytes } \\
\hline Tillandsia recurvata & - & 1 & $\mathrm{~V}$ \\
\hline
\end{tabular}

Scattered species in the canopy layer: yaicuaje (Exothea paniculata), yaba (Geoffroea inermis), dagame (Calycophyllum candidissimun), carbonero (Collubrina reclinata), almendrillo (Prunus myrtifolia), jaguey macho (Ficus membranacea), ayua (Zanthoxylum martinicensis), roble blanco (Tabebuia angustata) and ceiba (Ceiba pentandra).

Localities: Southern slope of Sierra Maestra.

$26^{\circ} \mathrm{C}$, with a mean annual high of $30-32^{\circ} \mathrm{C}$ and a mean annual low of $22-24^{\circ} \mathrm{C}$. The mean annual relative humidity is $75-80 \%$. Evaporation is 1700-1900 mm (Montenegro, 1991a, b, c, d). It rains about $1000 \mathrm{~mm}$ (slightly rainy limit), with a little rainy period from november to april and a rainy, from may to october. It is considered a tropical climate with dry winter, 4bTh subtype, with 5-6 dry months (semi-dry). 
The soil is reddish brown fersiallitic, very shallow, gravelly, with a percentage of stones from $50-80 \%$, exceptionally lower. This forest type occupies the middle and lower zones of the microbasin, so their water situation is relatively more favorable than in the upper basins. Due to the large slope, withered leaves are very sparse where it accumulates. Sometimes among the stones, an L layer $(1-2 \mathrm{~cm})$ and a generally imperceptible $\mathrm{F}$ are observed. Sometimes such layers are mixed.
Therefore, it is considered as a dry (1) and little fertile (A) edatope, so its potential productive capacity is considered bad (IV). The typology classification is as follows $\mathrm{A}_{\mathrm{xx}-\mathrm{xxx}} 1$, $4 \mathrm{bTh}_{\mathrm{b}-\mathrm{c}}$, IV, T.h., G.u.

Distribution. It was studied at the bottom of the southern slope of Sierra del Turquino.

Terms for forest management. This forest can be enriched with cedar, mahogany, baría, yarúa and ayúa.

Table 21. Characteristic combination of jubabán with guásima

(Trichilia hirta with Guazuma ulmifolia, 6 plots)

\begin{tabular}{|c|c|c|c|}
\hline Species & $\begin{array}{c}\text { Vertical } \\
\text { structure }\end{array}$ & $\begin{array}{c}\text { Abundance- } \\
\text { Coverage }\end{array}$ & Presence Degree \\
\hline \multicolumn{4}{|c|}{ Canopy layer } \\
\hline Guazuma ulmifolia & $\mathrm{D}$ & 4 & $\mathrm{~V}$ \\
\hline Senna atomaria & $\mathrm{I}$ & 2 & $\mathrm{~V}$ \\
\hline Trichilia hirta & $\mathrm{D}$ & 1 & $\mathrm{~V}$ \\
\hline Spondias mombin & $\mathrm{C}$ & 1 & $\mathrm{~V}$ \\
\hline Cordia gerascanthus & $\mathrm{C}$ & 1 & $\mathrm{~V}$ \\
\hline Carpodiptera cubensis & $\mathrm{I}$ & 1 & $\mathrm{~V}$ \\
\hline Thouinia patentinervis & I & 1 & $\mathrm{~V}$ \\
\hline Coccothrinax gundlachii & $\mathrm{I}$ & 1 & $\mathrm{~V}$ \\
\hline Bursera simaruba & $\mathrm{C}$ & 1 & IV \\
\hline Celtis trinervia & $\mathrm{I}$ & 1 & III \\
\hline \multicolumn{4}{|c|}{ Shrub layer } \\
\hline Varronia globosa subsp. humilis & - & 2 & $\mathrm{~V}$ \\
\hline Phyllostylon brasiliensis & - & 1 & $\mathrm{~V}$ \\
\hline Erythroxylum havanense & - & 1 & $\mathrm{~V}$ \\
\hline \multicolumn{4}{|c|}{ Herbaceous layer } \\
\hline Melochia nodiflora & - & 1 & $\mathrm{~V}$ \\
\hline Lantana montevidensis & - & 1 & $\mathrm{~V}$ \\
\hline Desmodium incanum & & 1 & $\mathrm{~V}$ \\
\hline Commelina elegans & - & 1 & $\mathrm{~V}$ \\
\hline Wissadula amplissima & - & 1 & $\mathrm{~V}$ \\
\hline Bothriochloa pertusa & - & 1 & $\mathrm{~V}$ \\
\hline Urochloa humidicola & - & 1 & IV \\
\hline Pavonia fructicosa & - & 1 & IV \\
\hline Abutilon sp. & - & 1 & IV \\
\hline Eupatorium sp. & - & 1 & III \\
\hline Harrisia eriophora & - & 1 & III \\
\hline Malpighia suberosa & - & 1 & III \\
\hline Picramnia pentandra & - & 1 & III \\
\hline Bidens pilosa & - & 1 & III \\
\hline \multicolumn{4}{|c|}{ Lianas } \\
\hline Centrosema virginianum & - & 1 & $\mathrm{~V}$ \\
\hline Gouania lupuloides var. lupuloides & - & 1 & $\mathrm{~V}$ \\
\hline Stigmaphyllon sagreanum & - & 1 & $\mathrm{~V}$ \\
\hline Serjania diversifolia & - & 1 & IV \\
\hline Plumbago scandens & - & 1 & IV \\
\hline Passiflora suberosa & - & 1 & III \\
\hline \multicolumn{4}{|c|}{ Epiphytes } \\
\hline Tillandsia recurvata & - & 1 & $\mathrm{~V}$ \\
\hline
\end{tabular}

Scattered species in the canopy layer: cuabilla, yarúa, bayúa (Zanthoxylum elephantiasis), yaba and lirio santana. Localities: Southern slope of Sierra del Turquino. 
Table 22. Characteristic combination of guárano with guásima

(Cupania americana with Guazuma ulmifolia, 4 plots)

\begin{tabular}{|c|c|c|c|}
\hline Species & $\begin{array}{c}\text { Vertical } \\
\text { structure }\end{array}$ & $\begin{array}{l}\text { Abundance- } \\
\text { Coverage }\end{array}$ & Presence Degree \\
\hline \multicolumn{4}{|c|}{ Canopy layer } \\
\hline Guazuma ulmifolia & $\mathrm{D}$ & 2 & $\mathrm{~V}$ \\
\hline Cupania americana & $\mathrm{D}$ & 2 & $\mathrm{~V}$ \\
\hline Cordia gerascanthus & $\mathrm{C}$ & 1 & $\mathrm{~V}$ \\
\hline Poeppigia procera & $\mathrm{C}$ & 1 & $\mathrm{~V}$ \\
\hline Trichilia hirta & $\mathrm{C}$ & 1 & $\mathrm{~V}$ \\
\hline Zanthoxylum martinicense & $\mathrm{C}$ & 1 & $\mathrm{~V}$ \\
\hline Roystonea regia & $\mathrm{C}$ & 1 & $\mathrm{~V}$ \\
\hline Senna atomaria & $\mathrm{I}$ & 2 & IV \\
\hline Cupania glabra & $\mathrm{C}$ & 1 & IV \\
\hline Samanea saman & $\mathrm{C}$ & 1 & IV \\
\hline Cecropia peltata & $\mathrm{C}$ & 1 & IV \\
\hline Cedrela odorata & $\mathrm{C}$ & 1 & IV \\
\hline Guarea guidonia & $\mathrm{C}$ & 1 & IV \\
\hline Piscidia piscipula & $\mathrm{I}$ & 1 & III \\
\hline \multicolumn{4}{|c|}{ Shrub layer } \\
\hline Casearia sylvestris var. sylvestris & - & 1 & $\mathrm{~V}$ \\
\hline Picramnia pentandra & - & 1 & $\mathrm{~V}$ \\
\hline Eugenia floribunda & - & 1 & IV \\
\hline Erythroxylum havanense & - & 1 & IV \\
\hline Casearia hirsuta & - & 1 & IV \\
\hline Sideroxylon foetidissimum subsp. foetidissimum & - & 1 & IV \\
\hline Chrysophylum oliviforme & - & 1 & IV \\
\hline Cordia collococca & - & 1 & III \\
\hline Psidium guajava & - & 1 & III \\
\hline Oxandra lanceolata. & - & 1 & III \\
\hline \multicolumn{4}{|c|}{ Herbaceous layer } \\
\hline Desmodium incanum & - & 1 & $\mathrm{~V}$ \\
\hline Urochloa humidicola & - & 1 & $\mathrm{~V}$ \\
\hline Lasiacis divaricata & - & 1 & $\mathrm{~V}$ \\
\hline Adiantum trapeziforme & - & 1 & $\mathrm{~V}$ \\
\hline Pavonia fruticosa & - & 1 & IV \\
\hline Spermacoce assurgens & - & 1 & IV \\
\hline Pharus glaber & - & 1 & IV \\
\hline Randia aculeata & - & 1 & III \\
\hline Chromolaena odorata & & 1 & III \\
\hline Oplismenus setarius & - & 1 & III \\
\hline Sida rhombifolia & - & 1 & III \\
\hline Capsicum frutescens & - & 1 & III \\
\hline Petiveria alliacea & - & 1 & III \\
\hline Campiloneurum phyllitidis & - & 1 & III \\
\hline \multicolumn{4}{|l|}{ 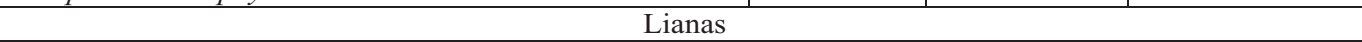 } \\
\hline Gouania lupuloides & - & 1 & $\mathrm{~V}$ \\
\hline Ipomoea alba & - & 1 & $\mathrm{~V}$ \\
\hline Pithecoctenium echinatum & - & 1 & $\mathrm{~V}$ \\
\hline Passiflora suberosa & - & 1 & IV \\
\hline Serjania diversifolia & - & 1 & IV \\
\hline Tournefortia hirsutissima & - & 1 & IV \\
\hline Pisonia aculeata & - & 1 & IV \\
\hline Salacia nipensis & - & 1 & III \\
\hline Trichostigma octandrum & - & 1 & III \\
\hline Cissampelos pareira & - & 1 & III \\
\hline Cissus verticillata & - & 1 & III \\
\hline Aristolochia lindeniana & - & 1 & III \\
\hline Plumbago scandens & - & 1 & III \\
\hline Hippocratea volubilis & - & 1 & III \\
\hline
\end{tabular}

Scattered species in the canopy layer: bijáguara, penda, jagua (Genipa americana), jatía, mije (Eugenia asperifolia), majaguilla, yaití, jobo, fustete (Clorophora tinctoria), yaba, anacahuita (Sterculia apetala), dagame, bien vestido (Gliricidia sepium), roble prieto, guatapaná, almácigo, guasimilla del pinar (Casearia arborea), yagruma hembra (Schefflera morotottoni), jaguey macho (Ficus membranacea), dairy (Sapium jamaicense) and guaguasí.

Localities: Sierra Maestra. 


\section{Guárano with guásima (Cupania americana with Guazuma ulmifolia; Table 22)}

Physiognomy and floristic composition. This secondary forest grows in the oecotopes from the semideciduous mesophyll forest and forms the late communities (fiera II and homeostasis II) under these conditions. The canopy layer varies according to the stage of development. In places where it is lower, it is between 7 and $8 \mathrm{~m}$, while in the more syngeneticaly evolved places it reaches from 12 to $15 \mathrm{~m}$. Cover is slightly sparse (usually $90 \%$ ), occasionally less. In the group of constant species, the main species are guásima and guárano (Cupania americana), while baría, tengue, jubabán, ayúa and royal palm are subdominants. In the group of accompanying species, frijolillo, algarrobo (Samanea saman), guárano hembra, yagruma (Cecropia peltata), cedar and yamagua (Guarea guidonia) are subdominants, while guamá candelon (Piscidia piscipula) is aggregated. The species from the shrub (media to high covers, 20-80\%) and herbaceous (media, 20-50\%) layers, as well as lianas and epiphytes are found in Table 22.

Oecotope characteristics. It takes place at an altitude between 200 and $625 \mathrm{~m}$ asl, on slopes of 20 to 40 degrees and in various exposures. It locates in low and premountain areas from Sierra Maestra. Rainfall is seasonal, between 900 and $1200 \mathrm{~mm}$, i.e., moderately rainy. The climate is tropical with dry winter, $4 c$ Th subtype, 3 to 4 months with little rain (moderately dry). Soils vary from fersiallitic and brown to ferrallitic, and from shallow to moderately deep, sometimes with stones on the surface. Humus is underdeveloped. The L layer is between 1 and $3 \mathrm{~cm}$. The F layer usually presents from vestiges to $0.3 \mathrm{~cm}$, only in structurally complex areas can reach $2 \mathrm{~cm}$ (with rootlets). H layer is not common; exceptionally, in the above described sites can be, in dispersed form, up to $0.3 \mathrm{~cm}$. Therefore, the edatope is moderately fertile (B), from dry to fresh (1-2), and the potential productive capacity is considered as regular (III). The typology classification is $\mathrm{B}_{\mathrm{x}} 1-2,4 \mathrm{cTh} \mathrm{b}_{\mathrm{b}-\mathrm{c}}$, III, C.a., G.u.

Distribution. This type of forest is the average conditions of semideciduous mesophyll forest in the Sierra Maestra.

Terms for forest management. It is rich in species, 44 tree species are observed. Then, its treatment is to keep it as such, so that it can develop its full potential. Corresponding oecotopes to such type of forest can be restored with species such as cedar, mahogany, yarúa, baría, ayúa, jocuma, bijáguara and dagame, forming a mixed forest.

\section{Amoroso with guásima (Zanthoxylum fagara with Guazuma ulmifolia; Table 23)}

Physiognomy and floristic composition. This secondary forest successive stage known as fiera II. The canopy layer increases in size with the development of the forest, from 6-8 m to $10-12 \mathrm{~m}$ and is considered dense $(100 \%)$; in the lower parts, no real difference is observed between the canopy and the shrub layers. In the group of constants species guásima and frijolillo are dominant while guarano, guara, amoroso (Zanthoxylum fagara), guatapaná, algarrobo, raspalengua and caimitillo (Chrysophyllum oliviforme) are subdominants. In turn, in the group of accompanying species are subdominants: jatia, ipil ipil, mije (Eugenia floribunda), aguedita (Picramnia pentandra), guamá hediondo (Lonchocarpus blainii), aguedita sweet, guayaba (Psidium guajava) and jubabán. The composition of the other layers and sinusiaes are found in Table 23.

Oecotope characteristics. The micro relief is irregular and occupies preferably the middle and lower basins. The study was run at an altitude of 220 to $240 \mathrm{~m}$ asl, with a 15 to 39 degree slope and changing exposure. The climate is tropical with dry winter, $4 \mathrm{bTh}$ subtype, with 5 to 6 months of little rain (medium-dry). The average rainfall ranges from 1000 to $1200 \mathrm{~mm}$ and the average temperature is around $25^{\circ} \mathrm{C}$.

It lies on rocks of the undifferentiated the Cobre Group. Soils are yellowish brown, shallow, with noticeable sheet erosion and about $5 \%$ of rock at the surface. The withered leaves are often scattered, in the less structurally evolved parts $\mathrm{L}$ and $\mathrm{F}$ layers are mixed and are no thicker than a centimetre; on the contrary, at the more developed layers the $\mathrm{L}$ is about 1.5 $\mathrm{cm}$ and $\mathrm{F} 0.5 \mathrm{~cm}, \mathrm{H}$ is missing. The edatope is considered dry (1) and moderately fertile (B); therefore the potential production capacity is considered bad (IV). The typology classification is as follows B1, 4bTh , IV, Z.f., G.u.

Distribution. The study was run at the surroundings of the town El Cobre (Santiago de Cuba province).

Conditions of forest management. As advanced successive stage, it can be enriched with species of forest value such as cedar, mahogany, yarua, baria, jocuma, bijáguara and dagame, among others.

\section{Sigua with guara (Ocotea coriacea with Cupania glabra; Table 24)}

Physiognomy and floristic composition. The canopy layer varies between 7 and $15 \mathrm{~m}$ 
height and its cover is sparse, occasionally dense $(50-100 \%)$. In the group of constant species it is only so the sigua, while the guara, jaguey (Ficus laevigata), macaguey (toad), yellow lily and aguedita (Picramnia pentan$d r a$ ) are subdominants; as for the group of accompaning species, this category is present with ramon cow (Dendropanax arboreus), bone, aguedita (Celtis trinervia), cuabilla, moruro rojo, raspalengua and guairaje (Eugenia asperifolia). As aggregated species, there are: abey (Abarema glauca), ayua de sierra, baría and penda. The species in the shrub layer, low sometimes high (10-90\%), herbaceous (medium to high, 30-95\%) and the sinucias of lianas and epiphytes are found in Table 24.

Oecotope characteristics. The altitude varies from 480 to $645 \mathrm{~m}$ asl. The slope is irregular, as it is the exposure. The mean annual temperature is 20 to $22^{\circ} \mathrm{C}$ (Montenegro, 1991a). In the central area of the studied territory mean annual rainfall is $1634 \mathrm{~mm}$, varying in the analyzed years between 1216 and 2320 $\mathrm{mm}$. There are 94 rainy days (average), ranging between 76 and 111. Evaporation ranges from $1300-1500 \mathrm{~mm}$ and relative humidity between 80 and $85 \%$ (Montenegro, $1991 \mathrm{c}$, d). Accordingly there is a tropical weather with dry winter, 4cTh subtype, with 3-4 dry months (moderately dry).

This forest grows on limestone and marble. It is present in both the top and bottom of the mogotes in areas of reddish brown soil, or in dog tooth with cavities and diaclases with red soils, both very shallow. Generally, in this ecosystem, soil is highly involved in the recycling of nutrients. However, it occurs in less extreme conditions that macaguey (toad) with curujey and chicharrón, occupying the same territory. So it is considered a little fertile $\left(\mathrm{A}_{\mathrm{xxx}}\right)$ and dry trophism (1). The withered leaves well developed, with an $\mathrm{L}$ layer between 1.5 and $5 \mathrm{~cm} ; \mathrm{F}$ is 0.2 to $3 \mathrm{~cm}$, and an $\mathrm{H}$ sometimes converted into root mat 0.5 to $2.5 \mathrm{~cm}$, of roots and rootlets embedded in a matrix of humus. In places with more soil, this root mat is smaller, with little humus; in this case there are more rootlets in the first soil horizon. Consistent with the difficult conditions in which this forest develops the potential productive capacity is considered bad (IV). The typology classification is as follows $\mathrm{A}_{\mathrm{xxx}} 1,4 \mathrm{cTh}$, IV, Rm*, O.c., C.g.

Distribution. This type of forest is located in the geographical area known as Carso de Baire (Núñez \& Viña, 1989; Viña Bayés, 1991). It is present in Las Manuelas and La Pimienta.

Conditions of forest management. Due to the conditions under which this type of forest grows, managing only allows long-term selective extractions (30 or older) to avoid decreasing rates of valuable species from the forestry point of view.

\section{Yamagua with ramon cow (Guarea guidonia with Dendropanax arboreus; Table 25)}

Physiognomy and floristic composition. This type of forest, relatively rich in tree species with 58 , is a late secondary community (fiera II), resulting from the neglect of coffee plantations and / or alteration of the forest. It occupies scattered areas, because the corresponding sites are currently in use by agricultural ecosystems. However, it is considered that the full-grown community will have a floristic composition pretty similar to the current one.

The canopy layer is dense $(90-100 \%)$ and irregular in height, between 8 and $20 \mathrm{~m}$. In the group of constant species there are main ramon cow and yamagua whereas, the subdominant are: ayúa, baría, sigua, yagruma and royal palm. In the group of accompanying species guásima is subdominant and aggregate are: red cedar (Cedrela cubensis), jobo, jocuma, jaguey (Ficus membranacea), macagua, guaguasi, jaguey (Ficus suffucans), yaya, yaba, jubabán, aguedita sweet and bone.

In the shrub layer with a fundamentally media covers (20-30\%, exceptionally 60\%) and herbaceous low to high (10-90\%) are observed as seedlings and small trees: aguedita (Picramnia pentandra), raspalengua, ramon horse, guara, guarano, leviza, almendrillo (Prunus myrtifolia), ocuje (Calophyllum antillanum), guayabillo (Guettarda calyptrata), sweet potato laurel (Ocotea floribunda), caimitillo, pole box and aguedita (Celtis trinervia). Other species of these layers and sinusiaes are found in Table 25.

Oecotope characteristics. This forest is developed in the upper and lower mogotes which are formed by denudation plateaus, and dissected sharply (Viña Bayés, 1991), composed for limestones and marbles. The altitude varies in the two study areas (Las Manuelas, 190-200 $\mathrm{m}$ asl) and (La Pimienta, 565-650 $\mathrm{m}$ asl), the slope is between 8 and 35 degrees and exposure is north to south-southeast.

The annual rainfall mean in this area is 1 $634 \mathrm{~mm}$; from march to november the rainfall rate is over $100 \mathrm{~mm}$ while the dry season takes place from december to february, with only $15 \%$ of rainfall, so this area can be considered a tropical climate with dry winter, subtype $4 \mathrm{cTh}$, with 3 to 4 dry months (moderately dry). 
Table 23. Characteristic combination of amoroso with guásima (Zanthoxylum fagara with Guazuma ulmifolia, 3 plots).

\begin{tabular}{|c|c|c|c|}
\hline Species & $\begin{array}{l}\text { Vertica } \\
\text { structure }\end{array}$ & $\begin{array}{l}\text { Abundance- } \\
\text { Coverage }\end{array}$ & Presence Degree \\
\hline \multicolumn{4}{|c|}{ Canopy + shrub layers } \\
\hline Guazuma ulmifolia & $\mathrm{D}$ & 3 & $\mathrm{~V}$ \\
\hline Senna atomaria & $\mathrm{C}$ & 3 & $\mathrm{~V}$ \\
\hline Cupania americana & $\mathrm{C}$ & 1 & $\mathrm{~V}$ \\
\hline Cupania glabra & $\mathrm{C}$ & 1 & $\mathrm{~V}$ \\
\hline Acacia macracantha & $\mathrm{C}$ & 1 & $\mathrm{~V}$ \\
\hline Samanea saman & $\mathrm{C}$ & 1 & $\mathrm{~V}$ \\
\hline Zanthoxylum fagara & I & 1 & $\mathrm{~V}$ \\
\hline Casearia hirsuta & I & 1 & $\mathrm{~V}$ \\
\hline Chrysophyllum oliviforme & I & 1 & $\mathrm{~V}$ \\
\hline Phyllostylon brasiliensis & $\mathrm{D}$ & 1 & IV \\
\hline Leucaena leucocephala & $\mathrm{C}$ & 1 & IV \\
\hline \multicolumn{4}{|c|}{ Shrub layer } \\
\hline Eugenia floribunda & - & 1 & IV \\
\hline Picramnia pentandra & - & 1 & IV \\
\hline Lonchocarpus blainii & - & 1 & IV \\
\hline Casearia sylvestris var. sylvestris & - & 1 & IV \\
\hline Psidium guajava & - & 1 & IV \\
\hline \multicolumn{4}{|c|}{ Herbaceous layer } \\
\hline Chromolaena odorata & - & 1 & $\mathrm{~V}$ \\
\hline Erythroxylum havanense & - & 1 & $\mathrm{~V}$ \\
\hline Rivina humilis & - & 1 & $\mathrm{~V}$ \\
\hline Commelina elegans & - & 1 & $\mathrm{~V}$ \\
\hline Petiveria alliacea & - & 1 & $\mathrm{~V}$ \\
\hline Abutilon sp. & - & 1 & $\mathrm{~V}$ \\
\hline Pavonia typhalea & - & 1 & $\mathrm{~V}$ \\
\hline Trichilia hirta & - & 1 & IV \\
\hline Spermacoce laevis & - & 1 & IV \\
\hline Desmanthus virgatus & - & 1 & IV \\
\hline Phyla nodiflora & - & 1 & IV \\
\hline Turnera ulmifolia & - & 1 & IV \\
\hline Rauvolfia tetraphylla & - & 1 & IV \\
\hline Desmodium incanum & - & 1 & IV \\
\hline Adiantum trapeciforme & - & 1 & IV \\
\hline Varronia globosa ssp. humilis & - & 1 & IV \\
\hline Oeceoclades maculata & - & 1 & IV \\
\hline \multicolumn{4}{|c|}{ Lianas } \\
\hline Gouania lupuloides & - & 1 & $\mathrm{~V}$ \\
\hline Pisonia aculeata & - & 1 & $\mathrm{~V}$ \\
\hline Serjania diversifolia & - & 1 & $\mathrm{~V}$ \\
\hline Turbina corymbosa & - & 1 & $\mathrm{~V}$ \\
\hline Trichostigma octandrum & - & 1 & IV \\
\hline Smilax havanense & - & 1 & IV \\
\hline Lasiasis divaricata & - & 1 & IV \\
\hline Cissampelos pareira & - & 1 & IV \\
\hline Chiococca alba & - & 1 & IV \\
\hline Tournefortia hyrsutissima & - & 1 & IV \\
\hline Centrosema sp. & - & 1 & IV \\
\hline Stigmaphyllum lineare & - & 1 & IV \\
\hline Stigmaphyllum sagreanum & - & 1 & IV \\
\hline
\end{tabular}

Scattered species in the canopy layer: anacahuita, ayúa, yamagua, yagruma, Citharexylum sp., jobo, sigua, royal palm, pomarrosa (Zyzygium jambos), jagua, cedar, tengue, corojo (Gastrococos crispa) and jocuma. 
Table 24. Characteristic combination of sigua with guara

(Ocotea coriacea with Cupania glabra, 6 plots)

\begin{tabular}{|c|c|c|c|}
\hline Species & $\begin{array}{c}\text { Vertical } \\
\text { structure }\end{array}$ & $\begin{array}{l}\text { Abundance- } \\
\text { Coverage }\end{array}$ & Presence Degree \\
\hline \multicolumn{4}{|c|}{ Canopy layer } \\
\hline Ocotea coriacea & $\mathrm{D}$ & 2 & $\mathrm{~V}$ \\
\hline Cupania glabra var. glabra & $\mathrm{C}$ & 1 & $\mathrm{~V}$ \\
\hline Ficus laevigata & $\mathrm{C}$ & 1 & $\mathrm{~V}$ \\
\hline Guapira obtusata & $\mathrm{C}$ & 1 & $\mathrm{~V}$ \\
\hline Plumeria emarginata & I & 1 & $\mathrm{~V}$ \\
\hline Amyris elemifera & $\mathrm{C}$ & 1 & IV \\
\hline Drypetes alba & $\mathrm{C}$ & 1 & IV \\
\hline Celtis trinervia & I & 1 & IV \\
\hline Dendropanax arboreus & $\mathrm{C}$ & 1 & IV \\
\hline Abarema glauca & $\mathrm{C}$ & 1 & III \\
\hline Zanthoxylum cubense & $\mathrm{C}$ & 1 & III \\
\hline Cordia gerascanthus & $\mathrm{C}$ & 1 & III \\
\hline Citharexylum caudatum & I & 1 & III \\
\hline \multicolumn{4}{|c|}{ Shrub layer } \\
\hline Hyperbaena paucinervis & - & 1 & $\mathrm{~V}$ \\
\hline Picramnia pentandra & - & 1 & $\mathrm{~V}$ \\
\hline Cojoba arborea & - & 1 & IV \\
\hline Casearia hirsuta & - & 1 & IV \\
\hline Eugenia asperifolia & - & 1 & IV \\
\hline \multicolumn{4}{|c|}{ Herbaceous layer } \\
\hline Faramea occidentalis & - & 1 & $\mathrm{~V}$ \\
\hline Pharus glaber & - & 1 & IV \\
\hline Zamia angustifolia & - & 1 & IV \\
\hline \multicolumn{4}{|c|}{ Lianas } \\
\hline Chiococca alba & - & 1 & $\mathrm{~V}$ \\
\hline Philodendron lacerum & - & 1 & $\mathrm{~V}$ \\
\hline Selenicereus grandiflorus & - & 1 & $\mathrm{~V}$ \\
\hline Smilax havanensis & - & 1 & $\mathrm{~V}$ \\
\hline Lasiacis divaricata & - & 1 & IV \\
\hline Pisonia aculeata & - & 1 & III \\
\hline Smilax lanceolata & - & 1 & III \\
\hline Vanilla sp. & - & 1 & III \\
\hline \multicolumn{4}{|c|}{ Epiphytes } \\
\hline Hohenbergia penduliflora & - & 1 & $\mathrm{~V}$ \\
\hline Trichocentrum undulatum & - & 1 & $\mathrm{~V}$ \\
\hline Tillandsia fasciculata & - & 1 & $\mathrm{~V}$ \\
\hline Tillandsia usneoides & - & 1 & IV \\
\hline Peperomia magnoliaefolia & - & 1 & III \\
\hline Rhipsalis cassutha & - & 1 & III \\
\hline Pleurothallis sertularioides & - & 1 & III \\
\hline Tillandsia pruinosa & . & 1 & III \\
\hline
\end{tabular}

Scattered species in the canopy layer: carmín, roble macho (Tabebuia hypoleuca), aguedita dulce, palo de caja, yaya, yaicuaje, Ficus perforata, guayabillo (Guettarda calyptrata), yaití, royal palm, combretaceae, leviza (Licaria jamaicensis), Pithecellobium sp., guaguasí, canilla de venado (Citharexylum fruticosum), cupey (Clusia rosea), macagua (Pseudolmedia spuria), yellow jucaro (Buchenavia (tetraphylla) capitata), dominguito (Chionanthus domingensis), cuyá, Tabebuia sp., carbonero, maboa (Cameraria latifolia), chicharrón, ayúa, yagruma, ceiba, guásima and cedar. Localities: Carso de Baire. 
Table 25. Characteristic combination of yamagua with ramon cow

(Guarea guidonia with Dendropanax arboreus, 3 plots)

\begin{tabular}{|c|c|c|c|}
\hline Species & $\begin{array}{c}\text { Vertical } \\
\text { structure }\end{array}$ & $\begin{array}{l}\text { Abundance- } \\
\text { Coverage }\end{array}$ & Presence Degree \\
\hline \multicolumn{4}{|c|}{ Canopy layer } \\
\hline Dendropanax arboreus & $\mathrm{D}$ & 3 & V \\
\hline Guarea guidonia & $\mathrm{D}$ & 2 & V \\
\hline Cordia gerascanthus & $\mathrm{D}$ & 1 & $\mathrm{~V}$ \\
\hline Ocotea coriacea & $\mathrm{D}$ & 1 & $\mathrm{~V}$ \\
\hline Zanthoxylum martinicense & $\mathrm{D}$ & 1 & $\mathrm{~V}$ \\
\hline Cecropia peltata & $\mathrm{C}$ & 1 & $\mathrm{~V}$ \\
\hline Roystonea regia & $\mathrm{C}$ & 1 & $\mathrm{~V}$ \\
\hline Guazuma ulmifolia & $\mathrm{C}$ & 1 & IV \\
\hline Cedrela cubensis & $\mathrm{C}$ & 1 & III \\
\hline Spondias mombin & $\mathrm{C}$ & 2 & III \\
\hline Sideroxylon foetidissimum subsp. foetidissimum & $\mathrm{C}$ & 1 & III \\
\hline Ficus membranacea & $\mathrm{C}$ & 1 & III \\
\hline Pseudolmedia spuria & $\mathrm{C}$ & 1 & III \\
\hline Zuelania guidonia & $\mathrm{C}$ & 1 & III \\
\hline Bursera simaruba & $\mathrm{C}$ & 1 & III \\
\hline Ficus suffucans & $\mathrm{C}$ & 1 & III \\
\hline Oxandra lanceolata & I & 2 & III \\
\hline Geoffroea inermis & I & 1 & III \\
\hline Trichilia hirta & I & 1 & III \\
\hline Casearia sylvestris var. sylvestris & I & 1 & III \\
\hline Drypetes alba & I & 1 & III \\
\hline \multicolumn{4}{|c|}{ Shrub layer } \\
\hline Picramnia pentandra & - & 1 & $\mathrm{~V}$ \\
\hline Casearia hirsuta & - & 1 & $\mathrm{~V}$ \\
\hline Trophis racemosa & - & 1 & $\mathrm{~V}$ \\
\hline Cupania glabra & - & 1 & $\mathrm{~V}$ \\
\hline Licaria jamaicensis & - & 1 & IV \\
\hline Prunus myrtifolia & - & 1 & IV \\
\hline Calophyllum antillanum & - & 1 & III \\
\hline Guettarda calyptrata & - & 1 & III \\
\hline Coffea arabica & - & 1 & III \\
\hline Ocotea floribunda & - & 1 & III \\
\hline Erythroxylum areolatum & - & 1 & III \\
\hline \multicolumn{4}{|c|}{ Herbaceous layer } \\
\hline Cupania americana & - & 1 & V \\
\hline Pharus glaber & - & 1 & $\mathrm{~V}$ \\
\hline Adiantum trapeziforme & - & 1 & $\mathrm{~V}$ \\
\hline Erythroxylum havanense & - & 1 & IV \\
\hline Pavonia spinifex & - & 1 & IV \\
\hline Oeceoclades maculata & - & 1 & IV \\
\hline Oplismenus setarius & - & 1 & IV \\
\hline Chrysophyllum oliviforme & - & 1 & III \\
\hline Psychotria sp. & - & 1 & III \\
\hline Lithacne pauciflora & - & 1 & III \\
\hline Allophyllus cominia & - & 1 & III \\
\hline Celtis trinervia & - & 1 & III \\
\hline Faramea occidentalis & - & 1 & III \\
\hline Anthurium cubense & - & 1 & III \\
\hline Urera baccifera & - & 1 & III \\
\hline \multicolumn{4}{|c|}{ Lianas } \\
\hline Cissus verticillata & - & 1 & $\mathrm{~V}$ \\
\hline Pithecoctenium echinatum & - & 1 & IV \\
\hline
\end{tabular}




\begin{tabular}{|l|c|c|c|}
\hline Pisonia aculeata & - & 1 & IV \\
\hline Gouania lupuloides & - & 1 & IV \\
\hline Abrus precatorius & - & 1 & IV \\
\hline Trichostigma octandrum & - & 1 & III \\
\hline Hyperbaena sp. & - & 1 & III \\
\hline Passiflora suberosa & - & 1 & III \\
\hline Tournefortia glabra & - & 1 & III \\
\hline Chiococca alba & - & 1 & III \\
\hline Serjania subdentata & - & 1 & III \\
\hline Philodendron lacerum & - & 1 & III \\
\hline \multicolumn{2}{|c|}{ Epiphytes } & - & \\
\hline Tillandsia fasciculata & - & 1 & IV \\
\hline Tillandsia usneoides & - & 1 & III \\
\hline Campiloneurum phyllitidis & - & 1 & III \\
\hline
\end{tabular}

Scattered species in the canopy layer: bucare (Erythryna poeppigiana), Ficus laevigata, dominguito, yaicuaje, toad (Ocotea leucoxylon), penda, tabaco (Cordia sulcata), bien vestido (Gliricidia sepium), lechero (Tabernaemontana amblyocarpa), comecará (Eugenia aeruginea), siguaralla (Trichilia havanensis), aceitunillo (Beilschmiedia pendula), ayúa de sierra, moruro rojo (Cojoba arborea), dagame, Thouinia sp., cupey, guamá candelón, Eugenia sp., tengue, mije (Eugenia floribunda), yellow jucaro, cuajaní (Prunus occidentalis), dairy and guairaje (Eugenia axillaris).

It occurs where the ecological conditions are most favorable. Its topographic position, protected by narrow valleys between the mogotes, or rock masses in the upper part thereof, makes for limited exposure to the sunlight and natural windshield; this reduces the air circulation and its effect on evaporation transpiration. Because this set of factors, the water regime is relatively friendly.

The soil is brownish sialític (Hernández \& al., 1994), reddish, from shallow to moderately deep, with limestone rocks on the surface, which cover between 5 and $80 \%$. The L layer has between 1.5 and $3 \mathrm{~cm}$, the $\mathrm{F}$ layer varies from traces to $0.2 \mathrm{~cm}$ (with rootlets) and $\mathrm{H}$ is missing. In this forest, whose cycle of nutrients depends on the soil, the rate of withered leaves decomposition seems to be very quick (Herrera \& Rodriguez, 1988). Therefore, the edatope is considered fresh (2) and moderately fertile (B), so that the potential production capacity is considered as regular (III). The typology classification is considered $\mathrm{B}_{\mathrm{x}-\mathrm{xxx}}$ 2, 4cTh $\mathrm{d}_{\mathrm{d}}$ III, G.g., D.a.

Distribution. It is present in the area known as Carso de Baire.

Terms for forest management. This type of forest is rich in tree species, so it must be handled in order to obtain maximum development, freeing up the tops of the valuable species. Subsequently, extractions will be performed selectively.

\section{Yaya with jobo (Spondias mombin with Oxandra lanceolata)}

It consists of a gallery forest whose corresponding table is not presented since the mini- mum number of samples is nonexistent $(2$ plots). The canopy layer has two sublayers, the upper one is about $20 \mathrm{~m}$ high, with emergents of $25 \mathrm{~m}$, sometimes this layer reaches the latter height; the lower layer on the other hand is from 8 to $10 \mathrm{~m}$ high, occasionally between 12 to $15 \mathrm{~m}$; with a dense covert $(100 \%)$. In general there are 41 tree species present, the most abundant are: jobo (D, AC 3), yaya (I, $A C 2-3)$, yagruma (C, AC 2), guásima (D, AC $2)$, yamagua ( $\mathrm{D}, \mathrm{AC} 2)$, ramon cow $(\mathrm{C}, \mathrm{AC} 2)$ and macagua (D, AC 2). There are also constant, although not abundant: sigua (D, AC 1), guarano $(\mathrm{C}, \mathrm{AC} 1)$, guara (I, AC 1), royal palm (P, AC 1), jocuma (C, AC 1), jaguey male (Ficus membranacea, I, AC 1), jubabán (I, AC $1)$, ramon horse $(\mathrm{C}, \mathrm{AC} 1)$, ayua $(\mathrm{C}, \mathrm{AC} 1)$, guaguasi (I, AC 1), almacigo ( I, AC 1), yaba (I, AC 1), raspalengua (I, AC 1), baria (I, AC $1)$, ocuje $(C, A C 1)$ and caimitillo $(0, A C 1)$. As spread tree species there can be observed: moruro rojo (I, AC 1), cupey (Clusia rosea, I, AC 1), dagame (I, AC 1), Thouinia sp. (0, AC 1), leviza ( $0, \mathrm{AC} 1)$, guamá candelon (I, AC 1), washing jaguey (Ficus suffucans, I, AC 1), guairaje (Eugenia sp., 0, AC 1), aguedita sweet (I, AC 1), saithe arabic (Erythroxylum areolatum, I, AC 1), tengue (0, AC 1$)$, mije (Eugenia floribunda, 0, AC 1), bone (0, AC 1), yellow jucaro $(\mathrm{C}, \mathrm{AC} 1)$, cuajaní $(\mathrm{C}, \mathrm{AC} 1)$, almendrillo (I, AC 1), dairy (Sapium jamaicense, I, AC 1) and guairaje (Eugenia axillaris, $0, \mathrm{AC} 1)$.

The shrub layer has a media covert (20$30 \%$ ) and it is composed almost entirely of tree species. This covert is low in the herbaceous layer (approx. 10\%) and near half of its composition is tree species. 
Oecotope characteristics. Located near the river in the bottom of the slope and consequently receives the contribution of the runoff thereof. Besides, due to its topographic position it is affected by the gravitational night winds. Therefore, the water balance is favorable. The height is between 190 and $200 \mathrm{~m}$ a.s.l, the inclination from 8 to 35 degrees and exposure between east and north. The mean annual temperature is around $24^{\circ} \mathrm{C}$. The mean annual rainfall is between 1400 and $1600 \mathrm{~mm}$, so it is considered moderately rainy. The relative humidity varies from 80 to $85 \%$, whereas the evaporation varies from 1500 and $1700 \mathrm{~mm}$. For that reason, it is considered a tropical climate with dry winter, subtype $4 \mathrm{cTh}$, with 3-4 (moderately dry) dry months.

It is located on rocks of the Cobre Group, the soil is sialític brown, deep, with gravel $(20 \%)$; in addition it has 40 to $100 \%$ of rocks at the surface. Therefore the edatope is considered moderately wet (3) and fertile (C) and the potential productive capacity as good (II). The layers of humus are not well developed, the $\mathrm{L}$ is between 3.5 and $5 \mathrm{~cm}$ thick, covering about $80 \%$ of the surface, $\mathrm{F}$ is almost imperceptible, scattered among the rocks and gravel, while $\mathrm{H}$ is lacking. This type of withered leaves decomposition is known as quick.

The typology classification is as follows $\mathrm{C}_{\mathrm{xx}-\mathrm{xxx}} 3,4 \mathrm{cTh} \mathrm{c}-\mathrm{d}_{\mathrm{d}}$, II, O.1., S.m.

Distribution. The study was run at the middle of the Turquino river.

Terms for forest management. Due to its small size this forest should be preserved from any human activity. In the zone there are areas where it should be restored to mixed forests with the same species as currently presented.

\section{Almendrillo with yamagua (Prunus myrtifolia with Guarea guidonia; Table 26)}

Physiognomy and floristic composition. This evergreen forest (mesophytic) has a canopy layer with 24 species of trees (average samples), it is from 12 to $25 \mathrm{~m}$ high and its covert is dense $(90-100 \%)$. In the group of constant species there are as main species yamagua and ramon cow; as subdominants: boniatillo (Cinnamomum elongatum), toad (Ocotea leucoxylon), ayua, guarano, caimitillo, ramon horse, almendrillo, dominguito and aceitunillo (Beilschmiedia pendula). In the group of accompanying species there are as subdominant species: cuajaní, royal palm, sweet potato, laurel, macagua, palma boba (Prestoea acuminata var. montana), sweet aguedita, mije (Eugenia floribunda) and copal (Protium cubense). In turn, the aggregate species observed are moruro rojo, aguacatillo (Alchornea latifolia), yaicuaje (Matayba oppositifolia), dairy, Ocotea globosa, marañon de costa (Talauma orbiculata), jaguey male (Ficus membranacea) and bone.

In the shrub layer, with a media covert and 12.2 tree species (average samples) there are as aggregate: pole box, cupey, casmagua (Wallenia laurifolia) and manaca (Calyptronoma plumeriana). The other species of the shrub and herbaceous layers (covert media to high and 13.5 average tree species), ferns and lianas are found in Table 26.

Oecotope characteristics. It usually develops between 500 and $800 \mathrm{~m}$ asl (locally up to 900 $\mathrm{m}$ above sea level on the south side), the slopes vary between 30 and 40 degrees and the exposure are varied. The microrelief is generally flat. This forest occurs in evergreen forest floor; climate is tropical with dry winter, $4 \mathrm{cTh}$ subtype, 3 to 4 months with little rain (moderately dry). The rainfall varies between 1200 and $1800 \mathrm{~mm}$ of rain, a moderately rainy, with large differences in their length; the dry season is from November to April and rainy from May to October (Montenegro 1991a, b). The average annual temperature is relatively cool, fluctuates between 22 and $23{ }^{\circ} \mathrm{C}$ at the bottom and around $20^{\circ} \mathrm{C}$ at the top. At these altitudes (below $800 \mathrm{~m}$ asl), in the evenings and in mid-april to late October, relative insolation varies between 20 and $30 \%$, the rest of these months is 30 to $40 \%$. In the morning ranges from 40 to $60 \%$ (Montenegro, 1991e). This lowers the effect of drought.

It occurs on soils derived from rock the Cobre Group, mostly andesites, and these are mainly ferralitic brown, low to very shallow, sometimes with stones on the surface. The withered leaves are well developed, the $\mathrm{L}$ layer is between 2 and $7 \mathrm{~cm}$ thick; F varies from 0.5 to $3 \mathrm{~cm}$, whereas $\mathrm{H}$ is missing; nanodepretions sometimes in humus accumulations are observed with roots and rootlets. Therefore, it is considered as fresh edatopes (2) and moderately fertile (B), so that their potential production capacity is rated as regular (III). The typology classification is as follows B2, $4 \mathrm{cTh} h_{\mathrm{c}-\mathrm{d}}$, III, P.m., G.g.

Distribution. This type represents the submountain forests of the Sierra Maestra, i.e. evergreen mesophyllous forests (mesophytic), which were designated as manacales by León (1946) and as canelones by Samek (1974). At the top transitions of the mountain rainforests and bottom with mesophitic semi-deciduous forests. They were studied in the Sierra of Gran Piedra and Turquino river basin. 
Table 26. Characteristic combination of almendrillo with yamagua

(Prunus myrtifolia with Guarea guidonia, 4 plots)

\begin{tabular}{|c|c|c|c|}
\hline Species & $\begin{array}{c}\text { Vertical } \\
\text { structure }\end{array}$ & $\begin{array}{c}\text { Abundance- } \\
\text { Coverage }\end{array}$ & Presence Degree \\
\hline \multicolumn{4}{|c|}{ Canopy layer } \\
\hline Guarea guidonia & $\mathrm{D}$ & 2 & $\mathrm{~V}$ \\
\hline Dendropanax arboreus & $\mathrm{D}$ & 2 & $\mathrm{~V}$ \\
\hline Prunus myrtifolia & $\mathrm{C}$ & 1 & $\mathrm{~V}$ \\
\hline Ocotea leucoxylon & $\mathrm{C}$ & 1 & $\mathrm{~V}$ \\
\hline Cinnamomum elongatum & $\mathrm{C}$ & 1 & $\mathrm{~V}$ \\
\hline Zanthoxylum martinicense & $\mathrm{C}$ & 1 & $\mathrm{~V}$ \\
\hline Cupania americana & $\mathrm{C}$ & 1 & V \\
\hline Trophis racemosa & $\mathrm{C}$ & 1 & $\mathrm{~V}$ \\
\hline Chionanthus domingensis & $\mathrm{C}$ & 1 & V \\
\hline Beilschmiedia pendula & $\mathrm{C}$ & 1 & $\mathrm{~V}$ \\
\hline Chrysophyllum oliviforme & I & 1 & $\mathrm{~V}$ \\
\hline Prunus occidentalis & $\mathrm{C}$ & 1 & IV \\
\hline Roystonea regia & $\mathrm{C}$ & 1 & IV \\
\hline Ocotea floribunda & $\mathrm{C}$ & 1 & IV \\
\hline Pseudolmedia spuria & $\mathrm{C}$ & 1 & IV \\
\hline Prestoea acuminata var. montana & $\mathrm{I}$ & 1 & IV \\
\hline Casearia sylvestris var. sylvestris & $\mathrm{I}$ & 1 & IV \\
\hline Eugenia floribunda & I & 1 & IV \\
\hline Protium cubense & I & 1 & IV \\
\hline Cojoba arborea & $\mathrm{C}$ & 1 & III \\
\hline Alchornea latifolia & $\mathrm{C}$ & 1 & III \\
\hline Matayba oppositifolia & $\mathrm{C}$ & 1 & III \\
\hline Sapium jamaicense & $\mathrm{C}$ & 1 & III \\
\hline Ocotea globosa & $\mathrm{C}$ & 1 & III \\
\hline Talauma orbiculata & $\mathrm{C}$ & 1 & III \\
\hline Ficus membranacea & $\mathrm{C}$ & 1 & III \\
\hline Drypetes alba & $\mathrm{I}$ & 1 & III \\
\hline \multicolumn{4}{|c|}{ Shrub layer } \\
\hline Allophyllus cominia & - & 1 & III \\
\hline Gesneria sp. & - & 1 & III \\
\hline Palicourea alpina & - & 1 & III \\
\hline Clusia rosea & - & 1 & III \\
\hline Wallenia laurifolia & - & 1 & III \\
\hline Anthirea radiata & - & 1 & III \\
\hline Piper sp. & - & 1 & III \\
\hline Calyptronoma plumeriana & - & 1 & III \\
\hline \multicolumn{4}{|c|}{ Herbaceous layer } \\
\hline Oplismenus setarius & - & 1 & IV \\
\hline Oeceoclades maculata & - & 1 & IV \\
\hline Desmodium sp. & - & 1 & III \\
\hline Faramea occidentalis & - & 1 & III \\
\hline Psychotria $\mathrm{sp}$. & - & 1 & III \\
\hline Psychotria uliginosa & - & 1 & III \\
\hline Pavonia spinifex & - & 1 & III \\
\hline Lithachne pauciflora & - & 1 & III \\
\hline Peperomia sp. & - & 1 & III \\
\hline \multicolumn{4}{|c|}{ Ferns } \\
\hline Campyloneurum phyllitidis & - & 2 & $\mathrm{~V}$ \\
\hline Blechnum occidentale & - & 1 & $\mathrm{~V}$ \\
\hline Cyathea parvula & - & 1 & III \\
\hline Adiantum trapeciforme & - & 1 & III \\
\hline
\end{tabular}




\begin{tabular}{|c|c|c|c|}
\hline \multicolumn{4}{|c|}{ Lianas } \\
\hline Vitis tiliaefolia & - & 1 & V \\
\hline Pisonia aculeata & - & 1 & $\mathrm{~V}$ \\
\hline Gouania lupuloides & - & 1 & V \\
\hline Lygodium volubile & - & 1 & V \\
\hline Hyperbaena paucinervis & - & 1 & IV \\
\hline Trichostigma octan drum & - & 1 & IV \\
\hline Davila rugosa & - & 1 & IV \\
\hline Smilax lanceolata & - & 1 & IV \\
\hline Hippocratea volubilis & - & 1 & III \\
\hline Cissampelos pareira & - & 1 & III \\
\hline Passiflora sexflora & - & 1 & III \\
\hline Smilax havanensis & - & 1 & III \\
\hline Serjania diversifolia & - & 1 & III \\
\hline
\end{tabular}

Scattered species in the canopy layer: bucare, camaguilla (Myrsine coriacea), cuero (Guettarda monocarpa), penda, Clusia sp., Colubrina sp., Cassia sp., aguedita (Picramnia pentandra), yareicillo (Myrcia fenzliana = Gomidesia lindeniana), pomarrosa, yaya, Ocotea globosa, jubilla (Sideroxylon jubilla), roble blanco (Tabebuia angustata), guaguasí, jocuma, Thouinia sp., yaicuaje, sarnilla cimarrona (Casearia sylvestris var. myricoides), cedar, yagruma hembra (Schefflera morotottoni), purio (Oxandra laurifolia) and ateje (Cordia collococca).

Forest management. These forests are rich in tree species and have been very impoverished, especially for growing coffee, meats and pastures, so the few remnants are severely threatened and must be protected. Many for this type of forest oecotopes should be restored to mixed forests, mainly: cedar, jubilla, jocuma, yamagua, boniatillo, almendrillo, cuajaní, sweet potato laurel, coast marañon, ateje, purio, guarano, ayua, etc.

\section{Dominguito with palma boba (Chionanthus domingensis with Prestoea acuminata var. montana; Table 27)}

Physiognomy and floristic composition. This type of forest is a mountain rainforest. The height and density of the canopy layer (averaging 15.5 species among samples) are presented fairly uniform; height fluctuates between 12 and $15 \mathrm{~m}$, while coverage is dense $(90-100 \%)$. In the group of constant species, palma boba, ramon cow and dominguito are main species; while toad, canelón (Ocotea cuneata), guárano, yaicuaje, aceitunillo and yareicillo (Myrcia fenzlian) are subdominants. In the group of accompanying species, cupey (Clusia tetrastigma), barril, pomarrosa and boniatillo are subdominants, while in the group of aggregated species are, cuajaní and purio fangar (Guatteria neglecta).

The shrub and herbaceous layers with a covers from media to high (40-70\%) and high $(50-90 \%)$ respectively, ferns, lianas synusiaes and epiphytes are found in Table 27.
Oecotope characteristics. It takes place between 800 and $1120 \mathrm{~m}$ asl, the inclination is among 30 and 45 degrees, and exposures are mainly to the north.

The weather station in Gran Piedra reports the following data (Montenegro, 1990): $29^{\circ} \mathrm{C}$ as absolute maximum temperature, $6{ }^{\circ} \mathrm{C}$ as absolute minimum temperature, $18.4{ }^{\circ} \mathrm{C}$ as average temperature, relative humidity at $89.6 \%$, mean annual rainfall of $1664 \mathrm{~mm}$ (rainy), 139 days with rain on average, sunshine average 5 to 7 hours / day. Prevailing winds are the trade's from the northeast and northnortheast, which in turn are also the strongest. The average number of days with horizontal precipitation (fog and low cloud) is 238; of them 162 days are with dense fog (Montenegro, 1990). These horizontal precipitations, according Boytel Yambú (1972), come to moisten the soil and vegetation; while Samek \& Travieso (1968) exposed that they can represent up to $50 \%$ of rainfall. Therefore, their importance as moisture providers is critical, as well as for limiting its loss in the ecosystem. Bioclimatically, the climate is moist Tropical Mountain (7a). Vilamajó \& al. (1989) considered it as of termoxeric type (wet equatorial).

Soil is leachate red ferralitic (sensu Hernández \& al., 1994) or yellowish brown. It derived from rocks of the Cobre Group, mainly from andesites. It is very poor (Renda, 1989; Renda \& al., 1980, 1981), moderately fertile (B) and fresh (2), so its potential productive capacity is considered regular (III). It has good internal and surface drainage. The 
withered leaves are well distributed on the surface; the L layer reaches from 3 to $5 \mathrm{~cm}$; $\mathrm{F}$ and $\mathrm{H}$ layers are mixed, sometimes forming a weft that can reach up to $10 \mathrm{~cm}$ thick, sometimes it gets to be a real root mat. The typology classification is as follows $\mathrm{B} 2,7 \mathrm{a}_{\mathrm{e}}$, III, Rm*, Ch.d., P.a.

Distribution. It comes in the top of Sierra of Gran Piedra, from $800 \mathrm{~m}$ asl in the north side and locally $900 \mathrm{~m}$ asl in the south.

Table 27. Characteristic combination of dominguito with palma boba

(Chionanthus domingensis with Prestoea acuminate, 9 plots)

\begin{tabular}{|c|c|c|c|}
\hline Species & $\begin{array}{c}\text { Vertical } \\
\text { structure }\end{array}$ & $\begin{array}{c}\text { Abundance- } \\
\text { Coverage }\end{array}$ & Presence Degree \\
\hline \multicolumn{4}{|c|}{ Canopy layer } \\
\hline Chionanthus domingensis & $\mathrm{D}$ & 2 & $\mathrm{~V}$ \\
\hline Prestoea acuminata var. montana & $\mathrm{D}$ & 2 & $\mathrm{~V}$ \\
\hline Dendropanax arboreus & $\mathrm{D}$ & 2 & V \\
\hline Ocotea leucoxylon & $\mathrm{D}$ & 1 & $\mathrm{~V}$ \\
\hline Cupania americana & $\mathrm{C}$ & 1 & $\mathrm{~V}$ \\
\hline Matayba oppositifolia & $\mathrm{C}$ & 1 & $\mathrm{~V}$ \\
\hline Ocotea cuneata & $\mathrm{C}$ & 1 & $\mathrm{~V}$ \\
\hline Beilschmiedia pendula & $\mathrm{C}$ & 1 & V \\
\hline Myrcia fenzliana (Gomidesia lindeniana) & $\mathrm{I}$ & 1 & $\mathrm{~V}$ \\
\hline Clusia tetrastigma & I & 2 & IV \\
\hline Cyrilla silvae & $\mathrm{C}$ & 1 & IV \\
\hline Syzygium jambos & $\mathrm{C}$ & 1 & IV \\
\hline Cinnamomum elongatum & $\mathrm{C}$ & 1 & IV \\
\hline Prunus occidentalis & $\mathrm{C}$ & 1 & III \\
\hline Guatteria neglecta & $\mathrm{C}$ & 1 & III \\
\hline \multicolumn{4}{|c|}{ Shrub layer } \\
\hline Gesneria viridiflora & - & 1 & $\mathrm{~V}$ \\
\hline Lyonia latifolia subsp. calycosa & - & 1 & III \\
\hline Ilex sp. & - & 1 & III \\
\hline \multicolumn{4}{|c|}{ Herbaceous layer } \\
\hline Callicarpa oblanceolata & - & 1 & $\mathrm{~V}$ \\
\hline Psychotria grandis & - & 1 & $\mathrm{~V}$ \\
\hline Phaius tankervilliae & - & 1 & IV \\
\hline Palicourea alpina & - & 1 & IV \\
\hline Hedyosmun grisebachii & - & 1 & IV \\
\hline Meriania leucantha var. nana & - & 1 & IV \\
\hline Oplismenus setarius & - & 1 & IV \\
\hline Columnea cubensis & - & 1 & IV \\
\hline Peperomia sp. 1 & - & 1 & III \\
\hline Coccoloba sp. & - & 1 & III \\
\hline Peperomia sp. 2 & - & 1 & III \\
\hline \multicolumn{4}{|c|}{ Ferns } \\
\hline Cyathea parvula & - & 1 & $\mathrm{~V}$ \\
\hline Blechnum occidentale & - & 1 & $\mathrm{~V}$ \\
\hline Cyathea aspera & - & 2 & IV \\
\hline \multicolumn{4}{|c|}{ Lianas } \\
\hline Philodendrum lacerum & - & 1 & III \\
\hline \multicolumn{4}{|c|}{ Epiphytes } \\
\hline Guzmania monostachya & - & 1 & $\mathrm{~V}$ \\
\hline Campiloneurum phyllitidis & - & 1 & III \\
\hline Diplazium sp. & - & 1 & III \\
\hline
\end{tabular}

Scattered species in the canopy layer: moruro rojo, sarnilla cimarrona, Ficus sp., palo de caja, aguacatillo, cletra (Clethra cubensis), guayacanejo (Coccoloba diversifolia), camaguilla (Myrsine coriacea), brunelia (Brunellia comocladifolia), roble macho (Tabebuia hypoleuca), almendrillo, roble blanco (Tabebuia angustata), marañon (Talauma sp.), penda, Ocotea globosa, yagruma, mije (Eugenia floribunda), cuero (Guettarda monocarpa), macagua, aguedita dulce, Hieronyma pallida, cupey (Clusia rosea), achotillo (Sloanea curatellifolia). 
Table 28. Characteristic combination of yareicillo with copey (Myrcia fenzliana (Gomidesia lindeniana) with Clusia tetrastigma, 8 plots

\begin{tabular}{|c|c|c|c|}
\hline Species & $\begin{array}{c}\text { Vertical } \\
\text { structure }\end{array}$ & $\begin{array}{c}\text { Abundance- } \\
\text { Coverage }\end{array}$ & Presence Degree \\
\hline \multicolumn{4}{|c|}{ Canopy layer } \\
\hline Clusia tetrastigma & $\mathrm{D}$ & 3 & $\mathrm{~V}$ \\
\hline Myrzia fenzliana (Gomidesia lindeniana) & I & 2 & $\mathrm{~V}$ \\
\hline Eugenia scaphophylla & $\mathrm{C}$ & 1 & $\mathrm{~V}$ \\
\hline Matayba oppositifolia & $\mathrm{C}$ & 1 & $\mathrm{~V}$ \\
\hline Ocotea leucoxylon & $\mathrm{C}$ & 1 & $\mathrm{~V}$ \\
\hline Coccoloba diversifolia & $\mathrm{C}$ & 1 & $\mathrm{~V}$ \\
\hline Alchornea latifolia & $\mathrm{C}$ & 1 & $\mathrm{~V}$ \\
\hline Clethra cubensis & $\mathrm{I}$ & 1 & $\mathrm{~V}$ \\
\hline Cyrilla silvae & $\mathrm{C}$ & 1 & IV \\
\hline Lyonia latifolia subsp. calycosa & I & 1 & IV \\
\hline Myrica cerifera & I & 1 & III \\
\hline \multicolumn{4}{|c|}{ Shrub layer } \\
\hline Ilex macfadyenii & - & 1 & $\mathrm{~V}$ \\
\hline Ossaea granulata & - & 1 & $\mathrm{~V}$ \\
\hline Palicourea alpina & - & 1 & $\mathrm{~V}$ \\
\hline Gesneria viridiflora & - & 1 & $\mathrm{~V}$ \\
\hline Myrsine coriacea & - & 1 & $\mathrm{~V}$ \\
\hline Ilex repanda & - & 1 & IV \\
\hline Citharexylum sp. & - & 1 & IV \\
\hline Guettarda valenzuelana & - & 1 & III \\
\hline Coccoloba wrightii & - & 1 & III \\
\hline \multicolumn{4}{|c|}{ Herbaceous layer } \\
\hline Scleria lithosperma & - & 1 & $\mathrm{~V}$ \\
\hline Panicum glutinosum & - & 1 & $\mathrm{~V}$ \\
\hline Psychotria sp. & - & 1 & IV \\
\hline Chionanthus domingensis & - & 1 & IV \\
\hline Prestoea acuminata var. montana & - & 1 & IV \\
\hline Eupatorium $\mathrm{sp}$. & - & 1 & IV \\
\hline Phaius tankervilliae & - & 1 & IV \\
\hline Olyra latifolia & - & 1 & IV \\
\hline Ichnanthus mayarensis & - & 1 & IV \\
\hline Vernonia hieracioides & - & 1 & III \\
\hline Oplismenus setarius & - & 1 & III \\
\hline Cinnamomum elongatum & - & 1 & III \\
\hline Piper sp. & - & 1 & III \\
\hline Chaptalia sp. & - & 1 & III \\
\hline \multicolumn{4}{|c|}{ Ferns } \\
\hline Cyathea parvula & - & 3 & $\mathrm{~V}$ \\
\hline Sticherus bifidus & - & 1 & IV \\
\hline Blechnum occidentale & - & 1 & IV \\
\hline Cyathea aspera & - & - & III \\
\hline Odontosoria scandens & - & 1 & III \\
\hline \multicolumn{4}{|c|}{ Lianas } \\
\hline Smilax havanensis & - & 1 & $\mathrm{~V}$ \\
\hline Smilax lanceolata & - & 1 & IV \\
\hline Arthrostylidium multispicatum & - & 1 & IV \\
\hline \multicolumn{4}{|c|}{ Epiphytes } \\
\hline Isochilus linearis & - & 1 & IV \\
\hline Tillandsia fasciculata & - & 1 & IV \\
\hline Guzmania monostachya & - & 1 & IV \\
\hline Dichaea hystricina & - & 1 & III \\
\hline
\end{tabular}

Scattered species in the canopy layer: aguedita dulce, ramon cow, cuero, guárano, cedar, cupey, roble macho, pomarrosa, purio prieto (Guatteria blainii), palo de caja, aceitunillo and canelón. 
Forest management. This rainforest is of inestimable hydrologic value, and also as protector of a very erodible soil. It has been highly altered; only relatively preserved relicts are left. It must be protected from any human intervention since it is part of a Biosphere Reserve (also Protected Area of Managed Resources) and it is its main object of conservation. Only controlled observation of its values and scientific research should be allowed.

\section{Yareicillo with copey [Myrcia fenzliana (Gomidesia lindeniana) with Clusia tetrastigma; Table 28]}

Physiognomy and floristic composition. This forest is a successional stage (homeostasis I and early fiera II) (sensu Capote \& al., 1988; Reyes \& Acosta, 2005) of the mountain rainforest in the Gran Piedra. Structurally, it can be considered as a shrubby forest and / or a tree scrub. A low canopy layer is present in the most evolved part (fiera II), between 7 and $10 \mathrm{~m}$ height and with a slightly sparse to dense (80-100\%) cover. In the group of accompanying species, barril and clavellina (Lyonia latifolia subsp. calycosa) are subdominants, while in the group of aggregated species, arraigán (Myrica cerifera) is. In the shrub layer, with a cover from media to very high $(40-100 \%)$ camaguilla is subdominant and Citharexylum sp., yaicuaje, yareicillo, vigueta (Guettarda valenzuelana) and uverillo (Coccoloba wrightii) are aggregated. In the herbaceous layer, with a cover of high to very high (80-100\%) are dominguito, palma boba, yareicillo, toad, yaicuaje, Eugenia scaphophylla, copey, boniatillo, guárano, canelón and camaguilla. The other species of the shrub and herbaceous layers, ferns, lianas and epiphytes are in the Table 28.

Oecotope characteristics. This community was studied in the highest parts of Sierra de la Gran Piedra, above $1000 \mathrm{~m}$ asl; inclination is variable, usually greater than 20 degrees, the exposure is diverse and the microrelief is regular. Weather conditions are avoided, as they are described in palma boba with dominguito.

Soil is leachate red ferralitic (Hernández \& al., 1994), poor and acid, usually deep, moderately fertile (B) and fresh (2), so its potential productive capacity is regular (III). Withered leaves are well developed. The L layer varies between 1.5 and $4 \mathrm{~cm}$, mostly between 2 and $2.5 \mathrm{~cm}$, while the $\mathrm{F}$ layer fluctuates between 1 and $2 \mathrm{~cm}$, exceptionally more. The $\mathrm{H}$ layer forms a root mat embedded in a matrix of humus. It is greater than $10 \mathrm{~cm}$ in the most advanced areas and littlte in smaller areas. At this successional stage, such root mat is the main element in the recirculation of nutrients in this ecosystem. Decomposition is very slow since plants that provide $75 \%$ or more of the observed withered leaves [copey, yareicillo, yaicuje, clavellina, fern (Cyathea parvula) and sometimes, tapa camino (Palicourea alpina) and aguacatillo] mainly provide a sclerophyllous material. The typology classification is as follows B2, 7a , III, Rm**, M.f., C.t.

Distribution. It locates in the top of Sierra de la Gran Piedra, up $1000 \mathrm{~m}$ asl.

Forest management. It must be protected from any human intervention as it is an early community (homeostasis I and early fiera II) from the mountain rainforest, typical of the place, and there are only isolated remnants.

\section{Pomarrosa with palma boba (Syzygium jambos with Prestoea acuminata var. montana)}

Physiognomy and floristic composition. This secondary forest, consisting of a gallery forest or isolated forest fragments ( 2 plots), is observed in Sierra de la Gran Piedra, about $1000 \mathrm{~m}$ asl in oecotopes of mountain rainforest. The canopy layer covers $100 \%$ of the area (dense coverage) and is from 12 to $15 \mathrm{~m}$ high. Pomarrosa (D, A-C 5) is observed as main species and copey (I, A-C 1) as subdominant. The shrub layer is variable, between 20 and $80 \%$ (medium coverage). Dominguito (A-C 2) and palma boba (A-C 2) are abundant. The herbaceous layer is dense, 80 to $100 \%$ with a diverse composition.

Ecology and distribution. Soils are shallow and with relatively plastic clay, which favors moisture retention; exposures are to the north and the inclination is 15 to 20 degrees. Weather conditions are avoided as they are described in dominguito with palma boba. The typology classification is considered as B2-3, $7 a_{\mathrm{e}}$, II-III, S.j., P.a.

Forest management. Pomarrosa gallery forests exceptionally protect the banks of streams and rivers, so its replacement must be gradual, in small areas, and only continue it after the treated area is consolidated. Dominguito, moruro rojo, Tabebuia spp., yaicuaje, palma boba, guárano, ramón cow and aguacatillo can be used as alternative species. Planting should be dense in order to achieve rapid coverage. The areas where forests are stable must be also partially substituted, by group, with species typical of mountain rainforest, including: purio fangar, yaicuaje, toad, aguacate cimarrón, barril, boniatillo, cuajaní, aguacatillo, roble de olor, ayúa, jubilla, macagua, etc. 
Purio fangar with marañón de la maestra (Guatteria neglecta with Magnolia cubensis; Table 29)

Physiognomy and floristic composition. This is a very complex type of forest, since they are late and mature communities of this mountain rainforest. It usually has between 39 and 53 species per inventory (species average of 48.6).

In its mature stage, it usually has a canopy layer between 18 and $20 \mathrm{~m}$ high, often up to 25 $\mathrm{m}$ or showing emerging until that point. Coverage is dense (typically 100\%). In the group of constant species, marañon de la maestra (Magnolia cubensis subsp. cubensis), yaicuaje, dominguito, purio fangar, toad, lengua de vaca (Ixora ferrea), aguacate cimarrón (Persea anomala), camaguilla, cletra, cordobán (Miconia pteroclada) and Viburnum villosum are main species. In the group of accompanying species, boniatillo, copeicillo (Clusia grisebachiana), cuajaní and ramon cow are subdominant species in this stratum; while barril, aguacatillo and roble de olor (Tabebuia brooksiana) are aggregated (Table 29). The shrub (thicket from medium to high, 40-70\%) and herbaceous (medium to high, 40$80 \%$ ) layers are rich in tree species.

Sometimes, pino de la maestra (Pinus maestrensis) forms successional stages (fiera II - homeostasis II) of this rainforest. In these places the pine tree forms a closed sub-layer of about 30 to $35 \mathrm{~m}$ tall. In addition, there is a second sub-layer between 10 and $16 \mathrm{~m}$ in height and of 50 to $60 \%$ coverage, exclusively composed by broadleaf from rainforests, where the most abundant species are dominguito (the most abundant), cordobán (Miconia dodecandra), cordobán (M. pteroclada), camaguilla, aguacatillo, boniatillo, lengua de vaca and brunelia.

In the successional stage homeostasis II, with exclusive participation of the broad-leaved species from the mountain rainforest, they form a dense canopy layer $(100 \%)$ with a height between 15 and $18 \mathrm{~m}$. Relict emergings are also seen of about $25 \mathrm{~m}$. Although it is young, an ecosystem balance is observed in this stage, as there is stability in the species of this forest type. The most abundant species are dominguito, purio fangar, yaicuaje, barril, copeicillo, boniatillo, aguacate cimarrón and other scattered species. At this stage there is a good development of the humus layers. The L layer is $3 \mathrm{~cm}$, $\mathrm{F}$ is $1.5 \mathrm{~cm}$ and $\mathrm{H}$ layer constitutes a root mat embedded in a matrix of humus of about $3 \mathrm{~cm}$.

Oecotope characteristics. It occupies the "floor of mountain rainforests", between 800 and $1400 \mathrm{~m}$ asl (low mountains), but it was mainly studied between 1200 and $1300 \mathrm{~m}$ asl The predominant slopes vary between 20 and 45 degrees and exposures are varied, the microrelief is also diverse. The climate is tropical moist mountain (7a). Rainfall is around $2000 \mathrm{~mm}$ (rainy weather), with fog and low clouds (usually dense) most days of the year, resulting in high atmospheric humidity. Main data are similar to those from the oecotope of palma boba with dominguito.

It develops mainly in the Cobre Group rocks, mainly tuffs, andesites and granites. The soil is leachate red ferrallitic (Renda, 1989), often deep, very poor and acidic, moderately fertile (B) and fresh (2), so its potential productive capacity is regular (III). It has good internal and external drainage. The $\mathrm{L}$ layer is between 1.5 and $3 \mathrm{~cm}$ thick, while the $\mathrm{F}$ layer generally ranges from 2 to $2.5 \mathrm{~cm}$. Root mat ranges from 6 to $13 \mathrm{~cm}$, sometimes up to 20 $\mathrm{cm}$ in nanodepressions. The tipology classification is considered as $\mathrm{B} 2,7 \mathrm{a}$, III, $\mathrm{Rm}^{*-* *}$, G.n., M.c.

Distribution. This type of forest grows in the highlands of Western Sierra Maestra.

Forest management. It must be protected from all human activity, even their successional stages, because due to its geomorphological position. Such position gives it a huge hydrological importance, and allows it to protect waters and an extremely erodible soil. Only controlled observation of its values and scientific research should be allowed. This should be prioritized especially in areas outside protected areas.

\section{Ferns with barril (Cyathea furfuracea and C. parvula with Cyrilla silvae)}

Initial forests that make up the ferns with barril are the successional stages homeostasis I and fiera II from the mountain rainforest in the Western Sierra Maestra. Cyrilla silvae and the tree ferns Cyathea furfuracea and $C$. parvula dominate the shrub-canopy layer. Each stage shows some structural and floristic differences, which allow separate studies, in two subtypes:

Ferns with barril,

Ferns with barril and yagruma macho.

Oecotope characteristics. It was studied between 1000 and $1400 \mathrm{~m}$ asl The ecological conditions are shown in purio fangar with marañón de la maestra (Guatteria neglecta with Magnolia cubensis). 
Table 29. Characteristic combination of purio fangar with marañón de la maestra (Guatteria neglecta with Magnolia cubensis, 9 plots)

\begin{tabular}{|c|c|c|c|}
\hline Species & $\begin{array}{l}\text { Vertical } \\
\text { structure }\end{array}$ & $\begin{array}{l}\text { Abundance- } \\
\text { Coverage }\end{array}$ & Presence Degree \\
\hline \multicolumn{4}{|c|}{ Canopy layer } \\
\hline $\mathrm{E}_{3,2,1}$ Magnolia cubensis subsp. cubensis & $\mathrm{P}$ & 1 & $\mathrm{~V}$ \\
\hline Guatteria neglecta & $\mathrm{D}$ & 1 & $\mathrm{~V}$ \\
\hline Matayba oppositifolia & $\mathrm{D}$ & 1 & $\mathrm{~V}$ \\
\hline Chionanthus domingensis & $\mathrm{D}$ & 1 & $\mathrm{~V}$ \\
\hline Ocotea leucoxylon & $\mathrm{D}$ & 1 & $\mathrm{~V}$ \\
\hline Ixora ferrea & $\mathrm{D}$ & 1 & $\mathrm{~V}$ \\
\hline Persea anomala & $\mathrm{D}$ & 1 & $\mathrm{~V}$ \\
\hline Myrsine coriacea & $\mathrm{I}$ & 1 & $\mathrm{~V}$ \\
\hline Clethra cubensis & I & 1 & $\mathrm{~V}$ \\
\hline $\mathrm{E}_{3,2}$ Miconia pteroclada & I & 1 & $\mathrm{~V}$ \\
\hline Viburnum villosum & I & 1 & $\mathrm{~V}$ \\
\hline $\mathrm{E}_{3,2,1}$ Dendropanax arboreus & $\mathrm{C}$ & 1 & IV \\
\hline Cinnamommum elongatum & $\mathrm{C}$ & 1 & IV \\
\hline Prunus occidentalis & $\mathrm{C}$ & 1 & IV \\
\hline $\mathrm{E}_{3,1}$ Clusia grisebachiana & I & 1 & IV \\
\hline $\mathrm{E}_{3,2,1}-$ Cyrilla silvae & $\mathrm{C}$ & 2 & III \\
\hline $\mathrm{E}_{3,1}$ Alchornea latifolia & $\mathrm{C}$ & 1 & III \\
\hline $\mathrm{E}_{3,2}$ Tabebuia brooksiana & $\mathrm{I}$ & 1 & III \\
\hline \multicolumn{4}{|c|}{ Shrub layer } \\
\hline $\mathrm{E}_{2,1}$ Meriania leucantha var. nana & - & 1 & $\mathrm{~V}$ \\
\hline Graffenrieda rufescens & - & 1 & $\mathrm{~V}$ \\
\hline Palicourea alpina & - & 1 & $\mathrm{~V}$ \\
\hline Psychotria grandis & - & 1 & $\mathrm{~V}$ \\
\hline Eugenia laeteviridis & - & 1 & $\mathrm{~V}$ \\
\hline Garrya fadyena & - & 1 & III \\
\hline Weinmannia pinnata & - & 1 & III \\
\hline Clidemia umbellata & - & 1 & III \\
\hline \multicolumn{4}{|c|}{ Herbaceous layer } \\
\hline $\mathrm{E}_{1}$ Zeugites americana & - & 1 & $\mathrm{~V}$ \\
\hline Arthrostylidium multispicatum & - & 1 & $\mathrm{~V}$ \\
\hline Hedyosmum grisebachii & - & 1 & III \\
\hline Panicum glutinosum & - & 1 & III \\
\hline Peperomia maculosa & - & 2 & III \\
\hline Begonia cubensis & - & 1 & III \\
\hline \multicolumn{4}{|c|}{ Ferns } \\
\hline $\mathrm{E}_{3}$ - Cyathea parvula & $\mathrm{I}$ & 1 & $\mathrm{~V}$ \\
\hline $\mathrm{E}_{3,2}$ Cyathea furfuracea & I & 1 & IV \\
\hline $\mathrm{E}_{2}-$ Alsophylla major & - & 1 & $\mathrm{~V}$ \\
\hline L- Odontosoria aculeata & - & 1 & IV \\
\hline Ep- Hymenophyllum sp. & - & 1 & IV \\
\hline Polybotria osmundacea & - & 1 & III \\
\hline Campiloneurum angustifolium & - & 1 & III \\
\hline Polypodium loriceum & - & 1 & III \\
\hline \multicolumn{4}{|c|}{ Epiphytes } \\
\hline Guzmania sp. & - & 1 & V \\
\hline Guzmania monostachya & - & 1 & IV \\
\hline Tillandsia fasciculata & - & 1 & IV \\
\hline Isochilos linearis & - & 1 & IV \\
\hline
\end{tabular}

Scattered species in the canopy layer: Ocotea spathulata, macaguey (toad), yagruma, ayúa, macagua, yareicillo, Sapium erythrospermum, almendrillo, guárano, jubilla, cordobán (Miconia dodecandra), pino de la maestra, palma boba, brunelia, Pimenta sp., ramon horse, achotillo (Hieronyma nipensis), Manilkara valenzuelana, bone, jiquí (Pera bumeliifolia), Ditta myricoides, Coccoloba sp. and vigueta. 
Ferns with barril (Cyathea furfuracea and C. parvula with Cyrilla silvae; Table 30)

Physiognomy and floristic composition. As stage of homeostasis I in oecotopes of this mountain rainforest, barril and tree ferns Cyathea parvula and C. furfuracea dominate the shrub canopy layer, with a height between 5 and $8 \mathrm{~m}$; occasionally reaching up to $12 \mathrm{~m}$. They usually close the canopy, with $100 \%$ coverage and more (superdense). This creates umbrophylle conditions and the original forest species enter within them. They reach this layer or are already in the below ones. Likewise, the pioneer species: cucaracha (Pteridium aquilinum var. arachnoideum), Dicranopteris pectinata, malva blanca (Urena lobata), rompezaraguey (Chromolaena odorata), etc, begin to disappear. In the group of constant species, barril, Cyathea parvula and $C$. furfuracea are main species. Lengua de vaca, camaguilla, copey, cletra and cordobán (Miconia dodecandra) are tree subdominant in shrub and herbaceous layers. Aguacatillo, brunelia, toad, marañon de la maestra and yaicuaje are agregated. Other species are shown in Table 30.

Humus diversification is clearly observed at this stage; an L layer of 1.5 to $3 \mathrm{~cm}$ is presented, as well as an F layer of 0.5 to $1.5 \mathrm{~cm}$. There are big differences in the $\mathrm{H}$ layer, from traces up to a well-developed root mat $10 \mathrm{~cm}$ thick.

Table 30. Characteristic combination of ferns with barril (Cyathea parvula and C. furfuracea with Cyrilla silvae, 7 plots)

\begin{tabular}{|c|c|c|c|}
\hline Species & $\begin{array}{r}\text { Vertical } \\
\text { structure }\end{array}$ & $\begin{array}{c}\text { Abundance- } \\
\text { Coverage }\end{array}$ & Presence Degree \\
\hline \multicolumn{4}{|c|}{ Canopy layer } \\
\hline Cyrilla silvae & $\mathrm{D}$ & 3 & $\mathrm{~V}$ \\
\hline Cyathea parvula & $\mathrm{D}$ & 3 & $\mathrm{~V}$ \\
\hline Cyathea furfuracea & $\mathrm{D}$ & 2 & $\mathrm{~V}$ \\
\hline \multicolumn{4}{|c|}{ Shrub layer } \\
\hline Ixora ferrea & - & 1 & $\mathrm{~V}$ \\
\hline Myrsine coriacea & - & 1 & $\mathrm{~V}$ \\
\hline Chromolaena sp. & - & 1 & $\mathrm{~V}$ \\
\hline Palicourea alpina & - & 1 & $\mathrm{~V}$ \\
\hline \multicolumn{4}{|c|}{ Shrubs and herbaceous layers } \\
\hline Alchornea latifolia & - & 1 & III \\
\hline Brunellia comocladifolia & - & 1 & III \\
\hline Ocotea leucoxylon & - & 1 & III \\
\hline Magnolia cubensis subsp. cubensis & - & 1 & III \\
\hline Ossaea granulata & - & 1 & III \\
\hline Mataybe oppositifolia & - & 1 & III \\
\hline Viburnum villosum & - & 1 & III \\
\hline \multicolumn{4}{|c|}{ Herbaceous layer } \\
\hline Clidemia umbellata & - & 1 & $\mathrm{~V}$ \\
\hline Clusia grisebachiana & - & 1 & IV \\
\hline Clethra cubensis & - & 1 & IV \\
\hline Miconia dodecandra & - & 1 & IV \\
\hline Panicum glutinosum & - & 1 & IV \\
\hline Coccocypselum lanceolatum & - & 1 & IV \\
\hline Zeugites americana & - & 1 & III \\
\hline Scleria lithosperma & - & 1 & III \\
\hline \multicolumn{4}{|c|}{ Ferns } \\
\hline Hypolepis nigrescens & - & 1 & IV \\
\hline Sticherus bifidus & - & 1 & III \\
\hline Dicranopteris pectinata & - & 1 & III \\
\hline \multicolumn{4}{|c|}{ Epiphytes } \\
\hline Guzmania monostachya & - & 1 & III \\
\hline
\end{tabular}

Scattered species in the canopy layer: roble de olor, cordobán (Miconia pteroclada), Eugenia laeteviridis, jubilla. 
Ferns with barril and yagruma macho (Cyathea furfuracea and C. parvula with Cyrilla silvae and Schefflera morotottoni; Table 31)

As it is known, the fiera II phase begins when tree species surpass the homeostasis I stratum, and competitively interact among them.

They form a canopy layer of 8 to $12 \mathrm{~m}$, with isolated individuals of $15 \mathrm{~m}$ and coverage from sparse to dense (50-100\%). barril, cordobán (Miconia dodecandra) and the Cyathea furfuracea and $C$. parvula ferns are in the group of constant species from the tree and shrub layers. Brunelia, aguacatillo, camaguilla are subdominant, as well as lengua de vaca and toad in the shrub layer. In the group of accompanying species, copeicillo is subdominant and yagruma macho (Schefflera morotottoni), cletra, cordobán (Miconia pteroclada), marañon de la maestra and Eugenia laeteviridis are aggregated species.

The shrub and herbaceous layers have a high density, 60 to $90 \%$ and 50 to $70 \%$, respectively, with various tree sprouts. Other species are found in Table 31.

Table 31. Ferns with barril and yagruma macho

(Cyathea furfuracea and C. parvula with Cyrilla silvae and Schefflera morotottoni, 7 plots)

\begin{tabular}{|c|c|c|c|}
\hline Species & $\begin{array}{c}\text { Vertical } \\
\text { structure }\end{array}$ & $\begin{array}{c}\text { Abundance- } \\
\text { Coverage }\end{array}$ & Presence Degree \\
\hline \multicolumn{4}{|c|}{ Canopy and shrub layers } \\
\hline Cyrilla silvae & $\mathrm{D}$ & 3 & $\mathrm{~V}$ \\
\hline Miconia dodecandra & $\mathrm{D}$ & 2 & $\mathrm{~V}$ \\
\hline Cyathea furfuracea & $\mathrm{D}$ & 2 & $\mathrm{~V}$ \\
\hline Cyathea parvula & $\mathrm{D}$ & 2 & $\mathrm{~V}$ \\
\hline Brunellia comocladifolia & $\mathrm{C}$ & 1 & $\mathrm{~V}$ \\
\hline Alchornea latifolia & $\mathrm{C}$ & 1 & $\mathrm{~V}$ \\
\hline Myrsine coriacea & $\mathrm{C}$ & 1 & $\mathrm{~V}$ \\
\hline Clethra cubensis & I & 1 & III \\
\hline Miconia pteroclada & $\mathrm{I}$ & 1 & III \\
\hline \multicolumn{4}{|c|}{ Shrub layer } \\
\hline Palicourea alpina & - & 2 & $\mathrm{~V}$ \\
\hline Ixora ferrea & - & 1 & $\mathrm{~V}$ \\
\hline Clidemia umbellata & - & 1 & $\mathrm{~V}$ \\
\hline Ocotea leucoxylon & - & 1 & $\mathrm{~V}$ \\
\hline Clusia grisebachiana & - & 1 & IV \\
\hline Chromolaena $\mathrm{sp}$ & - & 1 & IV \\
\hline Magnolia cubensis subsp. cubensis & - & 1 & III \\
\hline \multicolumn{4}{|c|}{ Herbaceous layer } \\
\hline Panicum glutinosum & - & 1 & $\mathrm{~V}$ \\
\hline Coccocypselum herbaceum & - & 1 & IV \\
\hline Eugenia laeteviridis & - & 1 & III \\
\hline Scleria lithosperma & - & 1 & III \\
\hline \multicolumn{4}{|c|}{ Ferns } \\
\hline Hypolepis nigrescens & - & 1 & $\mathrm{~V}$ \\
\hline Sticherus bifidus & - & 1 & III \\
\hline Dicranopteris pectinata & - & 1 & III \\
\hline \multicolumn{4}{|c|}{ Epiphytes } \\
\hline Guzmania monostachya & - & 1 & III \\
\hline \multicolumn{4}{|c|}{ Differential combination from ferns with barril and yagruma macho } \\
\hline Arthrostylidium multispicatum & - & 1 &. $\mathrm{~V}$ \\
\hline Passiflora sexflora & - & 1 & $\mathrm{~V}$ \\
\hline Blechnum fragile & - & 1 & $\mathrm{~V}$ \\
\hline Schefflera morotottoni & $\mathrm{C}$ & 1 & III \\
\hline Callicarpa ferruginea & - & 1 & III \\
\hline Oplismenus setarius & - & 1 & III \\
\hline Alsophylla major & & 1 & III \\
\hline Odontosoria jenmanii & - & 1 & III \\
\hline Elaphoglossum chartaceum & - & 1 & III \\
\hline
\end{tabular}

Scattered species in the canopy layer: yaicuaje, canelón, roble de olor, oreganillo (Weinmannia pinnata), dominguito and ramon cow. 


\section{Barril with marañon de la maestra (Cyrilla silvae with Magnolia cubensis; Table 32)}

Physiognomy and floristic composition. As zonal formation it is a cloud forest (Samek, 1975; Reyes, 2006, 2011-2012), also known as fresh forest (León, 1946; Samek, 1974) and elfin forest (Borhidi, 1996). In this forest, the canopy layer with 10 to $15 \mathrm{~m}$ in height is dense $(80-100 \%)$. Barril and marañon de la maestra are main species and the most abundant in the group of constant species. Cletra is subdominant in the group of accompanying species, while Henriettea ekmanii is aggregated. Other species from the shrub (media to high coverage, 40-70\%) and herbaceous (high, $50-80 \%$ ) layers are found in Table 32 .

Oecotope characteristics. It usually occurs in steep topographic positions, mostly between 40 and 45 degrees (Reyes \& Acosta, 2005 ) and with various exposures. In the range of altitudinal variation of this type of forest, the average temperatures at $1500 \mathrm{~m}$ a.s.l vary between $15.2{ }^{\circ} \mathrm{C}$ in the north slope and $15.5^{\circ} \mathrm{C}$ on the south side. It can also reach around 13 ${ }^{\circ} \mathrm{C}$ at $1972 \mathrm{~m}$ asl (Montenegro, 1991b). Although there are not direct measurements in the area occupied by this forest, it falls around $2000 \mathrm{~mm}$ of rain. The wettest period is from april or may to october and the less rainy period is from november to march or april (Trusov \& al., 1983). The mean annual relative humidity is between 85 and $90 \%$ (Montenegro, 1991c). Orographic clouds or mists occur almost every day of the year, and along with the rain, they bring lots of moisture into the forest (even in the dry season), the climate is high mountain tropical (7b).

From the geological point of view it occupies rocks from the Cobre Group, tuffs, tuffaceous sandstones, etc. (Méndez \& al., 1994). The predominant soil is leached yellow ferrallitic, which dominates above $1500 \mathrm{~m}$ asl According to Renda \& al. (1981b) and Renda (1989), the $\mathrm{pH}$ in the upper horizons is from acid to very acidic and it reaches values of 4.45 to 5.3 in water, and 3.5 to 4.15 in $\mathrm{ClK}$. The assimilable nitrogen varies from 0.80 to $11.08 \mathrm{mg} / 100 \mathrm{~g}$ and tends to sharply decrease in depth. Phosphorus is absent or in traces; assimilable potassium fluctuates between 3.0 and $10 \mathrm{mg} / 100 \mathrm{~g}$. The CCB (S value) is very low, generally ranging between 1.44 and 5.02 cmol (+). $\mathrm{kg}^{-1}$. CIC (T value) is from 2.5 to $18.75 \mathrm{cmol}(+) \cdot \mathrm{kg}^{-1}$. This shows the low degree of saturation and that the complex has little cation due to intense weathering process. Therefore, this edatope should be regarded as little fertile (A), fresh (2) and with a potential productive capacity bad (IV).

A distinctive feature of this forest is its well-defined humus layers (sensu Herrera \& Rodríguez, 1988). The L layer reaches about 2 $\mathrm{cm}$, occasionally more or less; F layer fluctuates between 1 and $2 \mathrm{~cm}$, and $\mathrm{H}$ layer is a welldeveloped root mat embedded in a matrix of humus, where the fine roots and rootlets are, and in which the nutrient cycle of this conspicuous ecosystem occurs (Reyes \& al., 2011).This means, that this poor, acidic soil, is only used for plant fixation (thick roots) and virtually does not take part in their energy source.

The tipology classfications is considered as A2, 7b, IV, Rm**, C.s., M.c.

Distribution. This cloud forest develops in the highest parts of Western Sierra Maestra, from about $1500 \mathrm{~m}$ above sea level to the top of Pico Real del Turquino. Its greatest extent is observed in the massifs of Turquino and La Maestrica de los Libertadores - La Bayamesa. In other places, there are only isolated fragments.

Forest management. Because of the ecology conditions (Reyes \& Fornaris, 2011), the vegetation growth is extremely slow and trees have small thicket and size. Due to its topographic and geomorphologic position, the highest value of this type of forest is the protection of soil and water. That is why; it must be preserved against all forms of human intervention. An area from high La Bayamesa (1572 $\mathrm{m}$ asl) was studied. This area was deforested in 1962 due to the triangulation of Sierra Maestra. Forty five years later, regeneration have not exceed three meters, so it is considered that its recovery to mature forest can last from 150 to 200 years; even the restoration of the root mat (basis for its nutrient cycling) is exceptionally slow. Its protecting value widely exceeds the one it may have as wood producer; therefore only controlled observation and scientific research should be allowed. 
Table 32. Characteristic combination of barril with marañon de la maestra

(Cyrilla silvae with Magnolia cubensis, 6 plots)

\begin{tabular}{|c|c|c|c|}
\hline Species & $\begin{array}{c}\text { Vertical } \\
\text { structure }\end{array}$ & $\begin{array}{c}\text { Abundance- } \\
\text { Coverage }\end{array}$ & Presence Degree \\
\hline \multicolumn{4}{|c|}{ Canopy layer } \\
\hline Cyrilla silvae & $\mathrm{D}$ & 3 & V \\
\hline Magnolia cubensis subsp. cubensis & $\mathrm{D}$ & 2 & $\mathrm{~V}$ \\
\hline Clusia grisebachiana & $\mathrm{C}$ & 1 & $\mathrm{~V}$ \\
\hline Ditta myricoides & $\mathrm{C}$ & 1 & $\mathrm{~V}$ \\
\hline Ixora ferrea & $\mathrm{C}$ & 1 & $\mathrm{~V}$ \\
\hline Chionanthus domingensis & $\mathrm{C}$ & 1 & $\mathrm{~V}$ \\
\hline Weinmannia pinnata & $\mathrm{C}$ & 1 & $\mathrm{~V}$ \\
\hline Brunellia comocladifolia & $\mathrm{I}$ & 1 & $\mathrm{~V}$ \\
\hline Myrsine coriacea & I & 1 & $\mathrm{~V}$ \\
\hline Clethra cubensis & I & 1 & IV \\
\hline Henriettea ekmanii & I & 1 & III \\
\hline \multicolumn{4}{|c|}{ Shrub layer } \\
\hline Graffenrieda rufescens & - & 3 & $\mathrm{~V}$ \\
\hline Purdiaea stenopetala var. stenopetala & - & 1 & $\mathrm{~V}$ \\
\hline Palicourea alpina & - & 1 & $\mathrm{~V}$ \\
\hline Ilex macfadyenii & - & 1 & $\mathrm{~V}$ \\
\hline Viburnum villosum & - & 1 & $\mathrm{~V}$ \\
\hline Lyonia elliptica & - & 1 & $\mathrm{~V}$ \\
\hline Eugenia laeteviridis & - & 1 & $\mathrm{~V}$ \\
\hline Guapira obtusata & - & 1 & IV \\
\hline \multicolumn{4}{|c|}{ Herbaceous layer } \\
\hline Hedyosmum grisebachii & - & 1 & V \\
\hline Lisianthius glandulosus & - & 1 & $\mathrm{~V}$ \\
\hline Scleria lithosperma & - & 1 & $\mathrm{~V}$ \\
\hline Zeugites americana & - & 1 & $\mathrm{~V}$ \\
\hline Ocotea spathulata & - & 1 & IV \\
\hline Ilex sp. & - & 1 & IV \\
\hline Callicarpa ferruginea & - & 1 & IV \\
\hline Sapium erythrospermum & - & 1 & III \\
\hline Phaius tankervilliae & - & 1 & III \\
\hline Peperomia tenella & - & 1 & III \\
\hline \multicolumn{4}{|c|}{ Ferns } \\
\hline Alsophylla major & - & 1 & $\mathrm{~V}$ \\
\hline Cyathea parvula & - & 1 & $\mathrm{~V}$ \\
\hline Odontosoria scandens & - & 1 & $\mathrm{~V}$ \\
\hline Sticherus bifidus & - & 1 & $\mathrm{~V}$ \\
\hline Trichomanes robustum & - & 1 & $\mathrm{~V}$ \\
\hline Cyathea furfuracea & I & 1 & IV \\
\hline Elaphoglossum chartaceum & - & 1 & IV \\
\hline Campiloneurum phyllitidis & - & 1 & III \\
\hline Politrichum sp. & - & 1 & III \\
\hline Polybotria osmundacea & - & 1 & III \\
\hline \multicolumn{4}{|c|}{ Epiphytes } \\
\hline Isochilus linearis & - & 1 & $\mathrm{~V}$ \\
\hline Catopsis cf. floribunda & - & 1 & IV \\
\hline
\end{tabular}

Scattered species in the canopy layer: Guatteria moralesii, macurije, cordobán (Miconia dodecandra), pino de la maestra and Wallenia sp.

Localities: highest altitudes of Sierra Maestra. 


\section{Conclusions}

Thirty five broadleaf forest types and / or subtypes were studied. The forest types and / or subtypes more abundant are those belonging to the semideciduous microphyll forest (12), followed by the mangroves and mountain rainforest with an equal amount (7).

The 27 forest types and / or subtypes without marine influence, with coastal and low altitude, $63 \%$, have a potential productive capacity(PPC) going from bad (44.4\%) to very bad $(18.5 \%)$, because the erosion decrease the effective deep and increased the stony in the soil horizon. The regular PPC (III) is prevailing in the mittel and mountain zone because of the great profundity of soil. In the highest forest type the PPC decrease again owing to the poorest $\mathrm{T}$ and $\mathrm{S}$ value.

In its characteristic combination the primary forests types there are richest in tree species (18.4) than the secondary (8.4); outstanding for its richness the presents from 500 to 800 $\mathrm{m}$ asl, and for poorness those closed to marine influence. It's outstanding that, the primary montane types are lianas poorest and epipytes and ferns are richest than the types at low altitude. Forest types above $800 \mathrm{~m}$ asl and mangroves are protection forests.

The tropical climate with 5 to 6 months little rainy (4bTh) is the most prevalent in Sierra Maestra.

\section{Acknowledgments}

Most of the samples were taken within the framework of two projects: "Biological diversity of Sierra Maestra and Nipe Sagua Baracoa mountain ranges" and "Environmental educational initiatives to encourage sustainable local development in protected areas of rainforests of the Eastern Cuban Region". Translation to English was made by Haydee Noemi Vidal Carrillo. We highly value your support.

\section{References}

Álvarez, P.A. \& Varona, J.O. 1988. Silvicultura. Ed. Pueblo y Educación, La Habana. 354 pp.

Álvarez, A.F., Mercadet, A. 2012. El sector forestal cubano y el cambio climático. Inst. Inv. Agr.-For. Min. Agric., La Habana. 248 pp.

Bisse, J. 1988. Árboles de Cuba.- Ed. Científico Técnica, La Habana. 384 pp.

Borhidi, A. 1991. Phytogeography and Vegetation Ecology of Cuba. Akad. Kiadó. Budapest. 857 pp.

Borhidi, A. 1996. Phytogeography and Vegetation Ecology of Cuba. 2 Ed. Akad. Kiadó. Budapest. 926 pp.

Boytel Yambú, F. 1972. Geografía eólica de Oriente. Inst. Cubano del Libro. 251 pp.

Braun-Blanquet, J. 1979. Fitosociología. Bases para el estudio de las comunidades vegetales. H. Blume ediciones, 820 pp. Madrid.

Budowski, G. 1985. La conservación como instrumento para el desarrollo. Ed. Univers. Estatal a Distancia. San José, Costa Rica. 398 pp.

Capote, R.P., Menéndez, L., García, E.E. \& Herrera, R.A. 1988. Sucesión Vegetal. In: Herrera, R.A., Menéndez, L., Rodríguez, M.A., García, E.E. (Eds.) Ecología de los bosques siempreverdes de la Sierra del Rosario, Cuba. Montevideo. ROSTLAC. Pp. 272-295.

CITMA (Ministerio de Ciencia, Tecnología y Medio Ambiente). 2014. V Informe Nacional al Convenio sobre la Diversidad Biológica. La Habana. 253 pp.

Comisión Cubano Hungara. 1976. Mapa geológico 1:100 000. Acad. Ci. Cuba, Acad. Ci. Hungary.

Crespo, S.E. 1989. Evaporación media anual. In: Nuevo Atlas Nacional de Cuba. Mapa 42. Pp. VI.4.1.

Del Risco, E. 2000a. Metodología para la tipificación de los bosques cubanos. Inst. Inv. For. (inéd). 29 pp.

Del Risco, E. 2000b. Tipología forestal. Curso Postgrado. Univ. Pinar del Río. 74 pp +3 anexos.

Del Risco, E. \& Samek, V. 1984. Estudio fitocenológico de los pinares de Pinar del Río y su importancia práctica para la silvicultura. Act. Bot. Cub. 29: 19-28.

Gagua, G., Zarembo, A. \& Izquierdo, A. 1989. Precipitación media anual. 1931-1972. In: Nuevo Atlas Nacional de Cuba. Pp. VI.3.1, mapa 24.

Hernández, A., Pérez Jiménez, J.M., Bosh, D. \& Rivero, L. 1994. Nueva Versión de Clasificación Genética de los Suelos de Cuba. Inst. Suelos, MINAG, La Habana. 66 pp.

Herrera, R.A. \& Rodríguez, M.E. 1988. Clasificación funcional de los bosques tropicales. In: Herrera, R.A., Menéndez, L., Rodríguez, M.A., García, E.E. (Eds.). Ecología de los bosques siempreverdes de la Sierra del Rosario, Cuba. Pp. 574-626. ROSTLAC, Montevideo.

Kopp, D. 1965. Richtlinie zur Standortsbeschreibung. Posdam Forst. Inst.

Lapinel, B. 1989. Temperatura media anual del aire. In: Nuevo Atlas Nacional de Cuba. Mapa 15. pp. VI.2.4. 
León (Hno.). 1946. Flora de Cuba. Vol. 1.. Contr. Ocas. Mus. Hist. Nat. del Colegio de la Salle Nr. 8, Habana. 441 pp.

Méndez, I., Rodríguez, R., Rodríguez, E., Fernández, A., Rodríguez, M. 1994. Atlas de rocas de la Sierra Maestra. Emp. Geominera de Oriente. 125 pp.

Montenegro, U. 1990. Informe con los datos climáticos de la Gran Piedra. Dpto. Meteorología de Santiago de Cuba. Academia de Ciencias de Cuba.

Montenegro, U. 1991a. Precipitación media anual. In: Atlas de Santiago de Cuba. Academia de Ciencias de Cuba, Santiago de Cuba. Mapa 33.

Montenegro, U. 1991b. Temperatura media anual. In: Atlas de Santiago de Cuba. Academia de Ciencias de Cuba, Santiago de Cuba. Mapa 26.

Montenegro, U. 1991c. Humedad relativa media anual. In: Atlas de Santiago de Cuba. Academia de Ciencias de Cuba, Santiago de Cuba. Mapa 28.

Montenegro, U. 1991d. Evaporación media anual. In: Atlas de Santiago de Cuba. Academia de Ciencias de Cuba, Santiago de Cuba. Mapa 31.

Montenegro, U. 1991e. Insolación media periodo lluvioso. In: Atlas de Santiago de Cuba. Academia de Ciencias de Cuba, Santiago de Cuba. Mapa 25.

Núñez Jiménez, A \& Viña Bayés, N. 1989. Regiones Naturales y Antrópicas. In: Nuevo Atlas Nacional de Cuba. pp. XII.2.1.

Parada, M.E. \& Torranzo, A.V. 2014. Ordenamiento forestal ambiental. Estudio de caso: cuenca embalse La Coca. Agric. Org. 20(2): 29-33.

Regal García, A. 1988. Estudio de las precipitaciones en la región Sur-oriental de Cuba. La Habana. Tes. Dipl. (inéd.). Fac. Geografía. Univ. Habana. 45 pp.

Renda, A. 1989. Particularidades edafológica-forestales de la región central de la Sierra Maestra. Mem. Doc. (inéd.). Ci. Agric. ISCA Habana, La Habana. 27 pp.

Renda, A., Calzadilla, E., Bouza, J.A., Arias, J., Valle, M. \& Pérez, N. 1980. Estudio edafológico, fisiográfico y agrisilvicultural de la Sierra Maestra, municipio Buey Arriba. MINAGRI, Centr. Inv. For., La Habana. 96 pp.

Renda, A., Calzadilla, E., Bouza, J.A. \& Valle, M. 1980-1981. Estudio sobre las condiciones edafológicas, fisiográficas y agrisilviculturales de la Sierra Maestra, Provincia Santiago de Cuba. MINAGRI, Centr. Inv. For., La Habana. 95 pp.

Renda, A., Calzadilla, E., Bouza J.A., Arias, J., Valle, M. \& Pérez, N. 1981a. Estudio edafológico - forestal y fisiográfico de la Sierra Maestra, municipio Bartolomé Masó. MINAGRI, Centr. Inv. For., La Habana. 123 pp.

Renda, A., Calzadilla, E., Bouza, J.A., Arias, J. \& Valle, M. 1981b. Estudio edafológico, fisiográfico y agrisilvicultural de la Sierra Maestra, municipio Guisa. MINAGRI, Centr. Inv. For., La Habana. 90 pp.

Renda, A., Calzadilla, E., Bouza, J.A., Arias, J., Valle, M. \& Pérez, N. 1981c. Estudio edafológico, forestal y fisiográfico de la Sierra Maestra, municipio Niquero. MINAGRI, Centr. Inv. For., La Habana. 63 pp.

Renda, A., Calzadilla, E., Bouza, J.A., Arias, J., Valle, M. \& Pérez, N. 1982. Estudio edafológico, físiográfico y agrisilvicultural de la Sierra Maestra, municipio Media Luna. MINAGRI, Centr. Inv. For., La Habana. 22 pp.

Reyes, O.J. 2006. Clasificación de la vegetación de la Sierra Maestra. Biodiversidad de Cuba Oriental, Vol. VIII. 28-42.

Reyes, O.J. 2011-2012. Clasificación de la vegetación de la Región Oriental de Cuba. Rev. Jard. Bot. Nal. 32-33: 59-71.

Reyes, O.J. \& Acosta Cantillo, F. 2003. Fitocenosis presentes en las áreas costeras del Sur de la Sierra Maestra. I. Comunidades con influencia marina. Foresta Veracruzana 5(2): 1-8.

Reyes, O.J. \& Acosta Cantillo, F. 2004. Fitocenosis presentes en las áreas costeras del sur de la Sierra Maestra. II. Órdenes Varronio-Phyllostyletalia y Rhytidophyllo-Plumerietalia. Foresta Veracruzana 6(1): 37-43.

Reyes, O.J., Martínez Quesada, E. \& Acosta Cantillo, F. 2004a. Comunidades secundarias de la Región Oriental de Cuba. I. Clase Bothriochloetea pertusae Reyes. Biodiversidad de Cuba Oriental, Vol.VII. pp. 92-102. Ed. Academia.

Reyes, O.J., Acosta Cantillo, F. \& Martínez Quesada, E. 2004b. Comunidades secundarias de la Región Oriental de Cuba. II. Clase Senno-Acacietea macracanthae Reyes. Biodiversidad de Cuba Oriental, Vol. VII. Pp. 102-115. Ed. Academia.

Reyes, O.J. \& Acosta Cantillo, F. 2005. Vegetación. Cuba: Parque Nacional La Bayamesa. In: Maceira, D., Fong, A., Alverson, W.S. \& Wachter, T. (Eds.). Rapid Biological Inventories 13. Pp. 43-50 \& Apénd. The Field Museum, Chicago. 
Reyes, O.J. \& Martínez Quesada, E. 2005. Fitocenosis presentes en las áreas costeras del sur de la Sierra Maestra. IV. Asociaciones Colubrino ellipticae-Gymnanthetum lucidae y Eugenio-Dipholidetum salicifoliae. Foresta Veracruzana 7(1): 47-52.

Reyes, O.J. \& Fornaris Gómez, E. 2011. Características funcionales de los principales bosques de Cuba Oriental. Polibotánica 32: 89-105.

Reyes, O.J., Portuondo, E., Vadel, E. \& Fornaris, E. 2011. Características fisonómicas y funcionales del bosque nublado de la Sierra Maestra. Moscosoa 17: 139-149.

Russó Milhet, I. 2015. La política forestal en Cuba. Agric. Org. 21(1): 6-7.

Samek, V. 1973. Pinares de la Sierra de Nipe; Estudio Sinecológico. Acad. Ci. Cuba, Ser. Forestal 14, La Habana. 58 pp.

Samek, V. 1974. Elementos de silvicultura de los bosques latifolios. Inst. Cub. Libro, Ci. Téc., La Habana. $291 \mathrm{pp}$.

Samek, V. 1975. Hohenstufengliederung der Sierra Maestra (Kuba) und die Vegetation der supramontanen Stufe. Arch. Bereich Waldbau Forstschutz, TU Dresden.

Samek, V. \& Travieso, A. 1968. Climaregiones de Cuba. Rev. Agric. 2: 5-23.

Schwanecke, W. 1970. Richlinie für die Bildung und Kartierung der Standortseiheiten im Hugelland und Mittellgebirge der DDR. Postdam, VEB Forstprojektierung.

Thomasius, H. 1965. Über einige Besonderhaiten der forstlichen Standortserkundung und -kartierun in den Tropen. Wiss. Zeitschrift TU Dresden 14: 753-768.

Trusov, I.I., Izquierdo, A. \& Díaz, L.R. 1983. Características espaciales y temporales de las precipitaciones atmosféricas en Cuba. Inst. Geogr. Acad. Ci. Cuba, La Habana. 150 pp + 10 maps.

Vilamajó, D., Capote, R.P., Fernández, M., Zamora, I. \& González, B. 1989. Mapa bioclimático de Cuba. In: Nuevo Atlas Nacional de Cuba. Inst. Geografía e ICGC. pp. X.

Viña Bayés, N. 1991. Carso. In: Atlas de Santiago de Cuba. Mapa 22. Acad. Ci. Cuba, Santiago de Cuba. 
Appendix 1. Scientific names (genus, specie and author) and common names from species used in the tables 1-32.

\begin{tabular}{|c|c|}
\hline Scientific names & Common names \\
\hline Abarema glauca (Urb.) Barneby \& J.W. Grimes & abey \\
\hline Abrus precatorius $\mathrm{L}$. & peonía \\
\hline Abutilon sp. & - \\
\hline Acacia macracantha H. \& B. ex Willd. & guatapaná \\
\hline Acrostichum danaefolium Lang. \& Fisch & acróstico \\
\hline Adelia ricinella $\mathrm{L}$. & jía blanca \\
\hline Adiantum trapeziforme $\mathrm{L}$. & culantrillo de monte \\
\hline Agave underwoodii Trelease & maguey \\
\hline Agave sp. & maguey \\
\hline Alchornea latifolia $\mathrm{Sw}$. & aguacatillo \\
\hline Allophyllus cominia (L.) Sw. & palo de caja \\
\hline Alsophylla major Caluff \& Shelton & - \\
\hline Alternanthera maritima (Mart.) Standl. & - \\
\hline Alvaradoa amorphoides Lieb. & aroma blanca \\
\hline Alvaradoa arborescens Griseb. & carmín \\
\hline Amyris elemifera $\mathrm{L}$. & cuabilla,.cuaba \\
\hline Anthirea radiata (Griseb.) Urb. & vera \\
\hline Anthurium cubense Engler & anturio \\
\hline Aristolochia lindeniana Duch. & - \\
\hline Arthrostylidium angustifolium Nash & tibisí \\
\hline Arthrostylidium multispicatum Pilger & tibisí \\
\hline Auerodendron cubensis Britt. \& Wils. & cocuyo de costa \\
\hline Avicennia germinans (L.) L. & black mangrove \\
\hline Bacopa monnieri (L.) Pennull var. monnieri & verdolaga de costa \\
\hline Begonia cubensis Hassk. & begonia \\
\hline Beilschmiedia pendula (Sw.) Benth. \& Hook. & aceitunillo \\
\hline Bidens pilosa $\mathrm{L}$. & romerillo \\
\hline Blechnum fragile (Liebm.) Morton \& Lellinger & - \\
\hline Blechnum occidentale $\mathrm{L}$. & - \\
\hline Bothriochloa pertusa (L.) A. Camus & camagueyana \\
\hline Bourreria setoso-hispida O.E. Schulz & - \\
\hline Bourreria virgata (Sw.) G. Don & cafecillo \\
\hline Bourreria sp. & - \\
\hline Brunellia comocladifolia Bonpl. & brunelia \\
\hline Bursera simaruba (L.) Sargent. & almácigo \\
\hline Caesalpinia vesicaria $\mathrm{L}$. & brasil \\
\hline Callicarpa oblanceolata Urb. & filigrana \\
\hline Calophyllum antillanum Britt. & ocuje \\
\hline Calyptronoma plumeriana (Martius) Lourtier & manaca \\
\hline Campiloneurum angustifolium (Sw.) Fée & - \\
\hline Campyloneurum phyllitidis (L.) C. Presl & pasa de negro \\
\hline Canella winterana (L.) Gaertn. & cúrbana \\
\hline Capparis cynophallophora $\mathrm{L}$. & aceitunillo \\
\hline Capparis flexuosa $\mathrm{L}$. & picha de perro \\
\hline Capparis grisebachii Eichl. & olivo \\
\hline Capsicum frutescens $\mathrm{L}$. & ají gaguao \\
\hline Carpodiptera cubensis Griseb. & majaguilla \\
\hline Casearia hirsuta Sw. & raspalengua \\
\hline Casearia sylvestris Sw. var. myricoides & sarnilla cimarrona \\
\hline Casearia sylvestris $\mathrm{Sw}$. var. sylvestris & aguedita dulce \\
\hline Castela spinosa Cronq. & abrojo de costa \\
\hline Catopsis cf. floribunda L. B. Sm. & curujey \\
\hline Cecropia peltata $\mathrm{L}$. & yagruma \\
\hline Cedrela cubensis Bisse & red cedar \\
\hline Cedrela odorata $\mathrm{L}$. & cedar \\
\hline
\end{tabular}




\begin{tabular}{|c|c|}
\hline Celtis trinervia Lam. & aguedita \\
\hline Cenchrus ciliaris $\mathrm{L}$. & guizazo \\
\hline Centrosema virginianum (L.) Benth. & crica de negra \\
\hline Cinnamomum elongatum (Nees) Kosterm. & boniatillo \\
\hline Cissampelos pareira $\mathrm{L}$. & bejuco prieto \\
\hline Cissus trifoliata $\mathrm{L}$. & bejuco uví \\
\hline Cissus verticillata (L.) D.H. Nicolson \& C. Jarvis & bejuco uví \\
\hline Citharexylum caudatum $\mathrm{L}$. & penda \\
\hline Citharexylum sp. & - \\
\hline Clethra cubensis A. Rich. & cletra \\
\hline Clidemia umbellata (Mill.) L.O. Wms. & cordobán \\
\hline Clusia rosea Jacq. & cupey \\
\hline Clusia tetrastigma Vesque & cupey \\
\hline Coccocypselum lanceolatum Aubl & - \\
\hline Coccoloba diversifolia Jacq. & guayacanejo \\
\hline Coccoloba uvifera Jacq. & uva caleta \\
\hline Coccoloba wrightii Lindau & uverillo \\
\hline Coccoloba $\mathrm{sp}$. & - \\
\hline Coccothrinax elegans Borhidi \& Mz. & yuraguana \\
\hline Coccothrinax fragans Burret & yuraguana \\
\hline Coccothrinax gundlachii León & yuraguana \\
\hline Coffea arabica $\mathrm{L}$. & cafeto \\
\hline Cojoba arborea (L.) Britt. \& Rose & moruro rojo \\
\hline Colubrina elliptica (Sw.) Brizicki \& Stearn. & carbonero \\
\hline Columnea cubensis (Urb.) Britt. & - \\
\hline Commelina elegans $\mathrm{K}$. & canutillo1 \\
\hline Commelina erecta $\mathrm{L}$. & canutillo \\
\hline Commicarpus scandens (L.) Standl. & bejuco de purgación \\
\hline Comocladia dentata Jacq. & guao \\
\hline Conocarpus erectus $\mathrm{L}$. & yana \\
\hline Corchorus sp. & - \\
\hline Cordia alba Jacq. & uvita \\
\hline Cordia collococca $\mathrm{L}$. & ateje \\
\hline Cordia gerascanthus $\mathrm{L}$. & baría \\
\hline Crossopetalum sp. & - \\
\hline Croton lucidus L. & cuaba de ingenio \\
\hline Cupania americana L. & guárano \\
\hline Cupania glabra $\mathrm{L}$. & guara \\
\hline Cupania glabra Sw. var. glabra & guara \\
\hline Cyathea aspera $(\mathrm{L}$.$) Sw.$ & - \\
\hline Cyathea furfuracea Baker & helecho \\
\hline Cyathea parvula (Jenm.) Domin & helecho \\
\hline Cynanchum sp.1 & - \\
\hline Cynanchum sp.2 & - \\
\hline Cyperus alternifolius $\mathrm{L}$. & paraguita \\
\hline Cyperus giganteus Vahl & - \\
\hline Cyrilla silvae Berazaín & barril \\
\hline Cyrtopodium punctatum (L.) Ldl. & cañuela \\
\hline Chaptalia sp. & - \\
\hline Chiococca alba (L.) Hitchc. & bejuco de berraco. \\
\hline Chionanthus domingensis Lam. & dominguito \\
\hline Chromolaena odorata (L.) King \& Robins. & rompezaraguey \\
\hline Chromolaena sp. & - \\
\hline Chrysophylum oliviforme L. & caimitillo \\
\hline Dalechampia scandens L. & - \\
\hline Davila rugosa Poit. & bejuco colorado \\
\hline Desmanthus virgatus (L.) Willd. & adormidera \\
\hline Desmodium incanum DC. & amor seco \\
\hline
\end{tabular}




\begin{tabular}{|c|c|}
\hline Desmodium sp. & - \\
\hline Dichaea hystricina Rchb. & - \\
\hline Dicliptera vahliana Nees & gallitos \\
\hline Dicranopteris pectinata (Willd.) Und. & pata de gallina \\
\hline Diospyrus grisebachii (Hiern.) Standl. & black ebony \\
\hline Diplazium sp. & - \\
\hline Distictis rhynchocarpa Urb. & bejuco logarte \\
\hline Ditta myricoides Griseb. & - \\
\hline Drypetes alba Poit. & bone \\
\hline Drypetes mucronata Griseb. & chicharrón \\
\hline Drypetes sp. & - \\
\hline Echites umbellata Jacq. & huevo de gallo \\
\hline Elaphoglossum chartaceum (Baker ex Jenm.) C. Christ. & - \\
\hline Eleocharis elegans (K.) R. \& S. & junco \\
\hline Eleocharis mutata (L.) R. \& S. & junco \\
\hline Encyclia sp. & - \\
\hline Epidendrum nocturnum Jacq. & flor de san pedro \\
\hline Epidendrum pygmaeum Hook. & - \\
\hline Erithalis fruticosa $\mathrm{L}$. & cuaba prieta \\
\hline Erythroxylum areolatum $\mathrm{L}$. & arabo carbonero \\
\hline Erythroxylum havanense Jacq. & jibá \\
\hline Erythroxylum rotundifolium Lunan & yarúa de costa \\
\hline Eugenia asperifolia Berg. & guairaje \\
\hline Eugenia axillaris (Sw.) Willd. & guairaje \\
\hline Eugenia floribunda West. & mije \\
\hline Eugenia maleolens Poir. & guairaje \\
\hline Eugenia scaphophylla $\mathrm{Wr}$. & - \\
\hline Eugenia sp. & guairaje \\
\hline Eupatorium sp. & - \\
\hline Euphorbia heterophylla L. & lechosa \\
\hline Exostema caribaeum (Jacq.) R. \& S. & lirio santana \\
\hline Exothea paniculata Radlk. & yaicuaje \\
\hline Faramea occidentalis (L.) A. Rich. & - \\
\hline Ficus laevigata Vahl & jaguey \\
\hline Ficus membranacea C. Wr. & jaguey macho \\
\hline Ficus suffucans Griseb. & jaguey \\
\hline Galactia sp. & - \\
\hline Garrya fadyena Hook. & - \\
\hline Geoffroea inermis Wr. & yaba \\
\hline Gesneria heterochroa Urb. & - \\
\hline Gesneria viridiflora (Dcne.) Kuntze. & - \\
\hline Gesneria sp. & - \\
\hline Gouania lupuloides (L.) Urb. & jaboncillo \\
\hline Graffenrieda rufescens Britt. \& Wils. & - \\
\hline Grisebachianthus plucheoides (Griseb.) King \& Robins. & - \\
\hline Guapira obtusata (Jacq.) Little & macaguey (toad) \\
\hline Guarea guidonia $(\mathrm{L}$.) Sleumer & yamagua \\
\hline Guatteria neglecta (Griseb.) P. Wils. & purio fangar \\
\hline Guazuma ulmifolia Lam. & guásima \\
\hline Guettarda calyptrata A. Rich. & guayabillo \\
\hline Guettarda elliptica Sw. & ciguilla \\
\hline Guettarda valenzuelana A. Rich. & vigueta \\
\hline Guettarda sp. & - \\
\hline Guzmania monostachya (L.) Rusby ex Mez & curujey \\
\hline Guzmania sp. & curujey \\
\hline Gymnanthes lucida Sw. & yaití \\
\hline Harrisia eriophora (Pfeiff.) Britt. & jijira \\
\hline Hedyosmun grisebachii Solms & - \\
\hline
\end{tabular}




\begin{tabular}{|c|c|}
\hline Helicteres semitriloba Bert. & tapa culo \\
\hline Helicteres $\mathrm{sp}$. & - \\
\hline Heliotropium indicum L. & alacrancillo \\
\hline Henriettea ekmanii (Urb.) Alain & - \\
\hline Hibiscus brasiliensis L. & palo peregrino \\
\hline Hippocratea volubilis $\mathrm{L}$. & bejuco de castaña \\
\hline Hymenophyllum sp. & - \\
\hline Hyperbaena paucinervis Urb. & picha jutía \\
\hline Hyperbaena sp. & - \\
\hline Hypolepis nigrescens Hook. & - \\
\hline Ichnanthus mayarensis (Wr.) Hitchc. & - \\
\hline Ilex macfadyenii (Walp.) Rehder & acebo cubano \\
\hline Ilex repanda Griseb. & vigueta naranjo \\
\hline Ilex sp. & - \\
\hline Ipomoea alba $\mathrm{L}$. & flor de $\mathrm{Y}$ \\
\hline Ipomoea sp. & - \\
\hline Isidorea polyneura (Urb.) Aiello. & - \\
\hline Isochilus linearis (Jacq.) R. Br. & - \\
\hline Ixora ferrea (Jacq.) Benth. & lengua de vaca \\
\hline Jatropha gossipifolia $\mathrm{L}$. & frailecillo \\
\hline Laguncularia racemosa (L.) Gaertn. & white mangrove \\
\hline Lantana camara $\mathrm{L}$. & filigrana \\
\hline Lantana montevidensis (Spreng.) Briq. & filigrana cimarrona \\
\hline Lantana reticulata Pers. & orégano cimarrón \\
\hline Lasiacis divaricata (L.) Hitchc. & tibisí chico \\
\hline Leucaena leucocephala (Lam.) De Wit & ipil ipil \\
\hline Licaria jamaicensis (Nees) Kost. & leviza \\
\hline Lisianthius glandulosus A. Rich. & - \\
\hline Lithacne pauciflora (Sw.) Beauv. & pito enano \\
\hline Lonchocarpus blainii $\mathrm{Wr}$. & guamá hediondo \\
\hline Lonchocarpus domingensis Urb. & guamá \\
\hline Ludwigia erecta (L.) H. Hara & - \\
\hline Lygodium volubile Sw. & - \\
\hline Lyonia elliptica (Small) Alain & clavellina \\
\hline Lyonia latifolia (A. Rich.) Griseb. subsp. calycosa & clavellina \\
\hline Lysyloma sabicu Benth. & sabicú \\
\hline Magnolia cubensis Urb. subsp. cubensis & marañón de la maestra \\
\hline Malpighia apiculata Urb. & - \\
\hline Malpighia cnide Spreng. & palo bronco \\
\hline Malpighia suberosa Small. & palo bronco \\
\hline Malvastrum corchorifolium (Desv.) Britt. & - \\
\hline Matayba oppositifolia (A. Rich.) Britt. & yaicuaje \\
\hline Maytenus buxifolia (A. Rich.) Griseb. & carne de vaca \\
\hline Melicoccus bijugatus Jacq. & mamoncillo \\
\hline Melochia nodiflora Sw. & malva colorada \\
\hline Meriania leucantha Sw. var. nana Triana & - \\
\hline Merrenia bisecta (Jacq.) Hall f. & aguinaldo de almendra \\
\hline Miconia dodecandra (Desv.) Cogn. & cordobán \\
\hline Miconia pteroclada Urb. & cordobán \\
\hline Mikania micrantha $\mathrm{K}$. & guaco \\
\hline Morinda royoc L. & piñipiñi \\
\hline Myrcia fenzliana O. Berg. (=Gomidesia lindeniana Berg.) & yareicillo \\
\hline Myrica cerifera $\mathrm{L}$ & arraigán \\
\hline Myrsine coriacea (Sw.) R. Br. ex Roem. & camaguilla \\
\hline Ocotea cuneata (Griseb.) Urb. & canelón \\
\hline Ocotea floribunda (Sw.) Mez & boniato laurel \\
\hline Ocotea globosa Schlecht. \& Cham. & - \\
\hline Ocotea leucoxylon (Sw.) Laness. & toad \\
\hline
\end{tabular}




\begin{tabular}{|c|c|}
\hline Octomeria tridentata Lindl. & - \\
\hline Odontosoria jenmanii Maxon & - \\
\hline Odontosoria scandens (Desv.) C. Christ. & tembladera \\
\hline Oeceoclades maculata (Ldl.) Ldl. & - \\
\hline Olyra latifolia $\mathrm{L}$. & tibisí \\
\hline Oplismenus setarius (Lam.) R. \& S. & cañamazo \\
\hline Oplonia tetrasticha (Wr. ex Griseb.) Stearn. & no me toques \\
\hline Ossaea granulata Urb. & - \\
\hline Oxandra lanceolata (Sw.) Baill. & yaya \\
\hline Palicourea alpina (Sw.) DC. & tapa camino \\
\hline Panicum glutinosum Sw. & pega pega \\
\hline Panicum sp. & - \\
\hline Paspalum breve Chase & cañamazo \\
\hline Passiflora foetida $\mathrm{L}$. & pasionaria hedionda \\
\hline Passiflora penduliflora Bert. & bejuco manteca \\
\hline Passiflora sexflora Juss. & pasionaria de cerca \\
\hline Passiflora suberosa L. & bejuco mantequilla \\
\hline Pavonia fructicosa (Mill.) Fawcett \& Rendle & tábano \\
\hline Pavonia spinifex (L.) Cav. & malaguilla de costa \\
\hline Peperomia maculosa (L.) Hook. & - \\
\hline Peperomia magnoliaefolia (Jacq.) A. Dietr. & - \\
\hline Peperomia rotundifolia (L.) K. & lengua de las mujeres \\
\hline Peperomia tenella A. Dietr. & - \\
\hline Peperomia sp. & - \\
\hline Peperomia sp. 1 & - \\
\hline Peperomia sp. 2 & - \\
\hline Persea anomala Britt. \& Wils. & aguacate cimarrón \\
\hline Petiveria alliacea $\mathrm{L}$. & anamú \\
\hline Phaius tankervilliae (Banks) Blume & - \\
\hline Pharus glaber $\mathrm{K}$. & pelo de perro \\
\hline Philodendron lacerum (Jacq.) Schott & bejuco lombricero \\
\hline Phyla nodiflora (L.) Greene & oro azul \\
\hline Phyllanthus epiphyllanthus L. & panetela \\
\hline Phyllostylon brasiliensis Cap. & jatía \\
\hline Picramnia pentandra $\mathrm{Sw}$. & aguedita \\
\hline Picrodendron baccatum Kruge \& Urb. & aceituna \\
\hline Pictetia mucronata (Griseb.) Beyra \& Lavin & - \\
\hline Pilosocereus brooksianus (Vamp.) Bol. \& Row. & jijira \\
\hline Pinus maestrensis Bisse & pino de la maestra \\
\hline Piper sp. & - \\
\hline Piscidia piscipula (L.) Sargent. & guamá candelón \\
\hline Pisonia aculeata $\mathrm{L}$. & zarza \\
\hline Pithecoctenium echinatum (Aubl.) Schum. & huevo de toro \\
\hline Platygyna dentata Alain & -2 \\
\hline Pleurothallis gelida Ldl. & flor de llantén \\
\hline Pleurothallis sertularioides (Sw.) Spreng. & - \\
\hline Plumbago scandens L. & malacara \\
\hline Plumeria emarginata Griseb. & lirio amarillo, suchel \\
\hline Poeppigia procera Presl. & tengue \\
\hline Politrichum sp. & - \\
\hline Polybotria osmundacea H. \& B. ex Willd. & - \\
\hline Polypodium aureum L. & - \\
\hline Polypodium loriceum $\mathrm{L}$. & - \\
\hline Polypodium polypodioides (L.) A.S. Hith. & - \\
\hline $\begin{array}{l}\text { Prestoea acuminata (Willd.) H.E. Moore var. montana (Graham) An. } \\
\text { Hend. \& Galeano }\end{array}$ & palma boba \\
\hline Protium cubense (Rose) Urb. & copal \\
\hline Prunus myrtifolia (L.) Urb. & almendrillo \\
\hline
\end{tabular}




\begin{tabular}{|c|c|}
\hline Prunus occidentalis $\mathrm{Sw}$. & cuajaní \\
\hline Pseudocarpidium avicennioides (A. Rich.) Millsp. & chicharrón \\
\hline Pseudolmedia spuria Griseb. & macagua \\
\hline Psidium guajava $\mathrm{L}$. & guayaba \\
\hline Psychotria grandis Sw. & tapa camino \\
\hline Psychotria uliginosa $\mathrm{Sw}$. & tapa camino \\
\hline Psychotria sp. & - \\
\hline Purdiaea stenopetala Griseb. var. stenopetala & - \\
\hline Randia aculeata $\mathrm{L}$. & agalla de costa \\
\hline Randia spinifex (R. \& S.) Standl. & espuela \\
\hline Rauvolfia tetraphylla $\mathrm{L}$. & alelí \\
\hline Ravenia leonis M. Vict. & arraiján \\
\hline Rhipsalis cassutha Gaertn. & disciplinilla \\
\hline Rhizophora mangle L. & red mangrove \\
\hline Rivina humilis L. & coralitos \\
\hline Roystonea regia (K.) O.F. Cook. & royal palm \\
\hline Salacia nipensis Britt. & - \\
\hline Samanea saman (Jacq.) Merr. & algarrobo \\
\hline Sapium erythrospermum Muell. Arg. & - \\
\hline Sapium jamaicense Sw. & dairy \\
\hline Savia bahamensis Britt. & hicaquillo \\
\hline Schefflera morotottoni (Aubl.) Mag., Stey. \& Frodin & yagruma macho \\
\hline Scirpus olneyi A. Gray & junco de tres filos \\
\hline Scleria lithosperma (L.) Sw. & cortadera \\
\hline Selenicerus grandiflorus (L.) Britt. \& Rose & flor del cáliz, pitahaya \\
\hline Senna atomaria (L.) Irwin. \& Barneby. & frijolillo \\
\hline Serjania diversifolia (Jacq.) Radlk. & bejuco angarilla \\
\hline Serjania subdentata Juss. & bejuco esquinado \\
\hline Sida rhombifolia L. & malva, malva de cochino \\
\hline Sideroxylon foetidissimum Jacq. subsp. foetidissimum & jocuma \\
\hline Sideroxylon salicifolium (L.) C.F. Gaertn. (=Dipholis salicifolia A. DC.) & cuyá \\
\hline Smilax havanensis Jacq. & alambrillo \\
\hline Smilax lanceolata $\mathrm{L}$. & zarzaparrilla \\
\hline Solandra longiflora Tuss. & palo guaco \\
\hline Spermacoce assurgens Ruiz \& Pavón & garro \\
\hline Spermacoce laevis Lam. & garro morado \\
\hline Spirotecoma sp. & - \\
\hline Spondias mombin L. & jobo \\
\hline Sticherus bifidus (Willd.) Ching & pata de gallina \\
\hline Stigmaphyllon lineare $\mathrm{Wr}$. & bejuco san pedro \\
\hline Stigmaphyllon sagreanum A. Juss. & bejuco san pedro \\
\hline Syzygium jambos (L.) Alston in Trimen & pomarrosa \\
\hline Tabebuia bibracteolata Griseb. & - \\
\hline Tabebuia brooksiana Britt. & roble de olor \\
\hline Tabebuia myrtifolia (Griseb.) Britt. & - \\
\hline Talauma orbiculata Britt. & marañón de costa \\
\hline Thouinia patentinervis Radlk. & negracuba \\
\hline Tillandsia balbisiana Schult. & curujey \\
\hline Tillandsia fasciculata Sw. & curujey \\
\hline Tillandsia pruinosa $\mathrm{Sw}$. & curujey \\
\hline Tillandsia recurvata $\mathrm{L}$. & curujey \\
\hline Tillandsia schiediana Stud. & curujey \\
\hline Tillandsia usneoides L. & barba de indio \\
\hline Tournefortia glabra $\mathrm{L}$. & nigua \\
\hline Tournefortia hirsutissima L. & nigua \\
\hline Tournefortia volubilis L. & nigua \\
\hline Tragia hexandra Jacq. & amansa guapo \\
\hline
\end{tabular}




\begin{tabular}{|c|c|}
\hline Tragia volubilis $\mathrm{L}$. & - \\
\hline Trema micrantha (L.) Blume & almez de flores pequeñas \\
\hline Trichilia hirta L. & cabo de hacha \\
\hline Trichocentrum undulatum (Sw.) Ackerman \& M.W. Chace & guataca de burro \\
\hline Trichomanes robustum Fourn. & - \\
\hline Trichostigma octandrum (L.) Britt. & bejuco de canasta \\
\hline Triopteris rigida $\mathrm{Sw}$. & amansa guapo \\
\hline Trophis racemosa (L.) Urb. & ramon horse \\
\hline Turbina corymbosa (L.) Raf. & aguinaldo de pascuas \\
\hline Turnera ulmifolia $\mathrm{L}$. & marilope \\
\hline Typha domingensis (Pers.) Kunth & macío \\
\hline Urera baccifera (L.) Gaud. & chichicate \\
\hline Urochloa humidicola (Rendle) Morrone \& Zuloaga & yerba de guinea \\
\hline Vanilla sp. & vainilla \\
\hline Varronia globosa L. & - \\
\hline Varronia globosa L. subsp. humilis & - \\
\hline Varronia lineata $\mathrm{L}$. & - \\
\hline Vernonia hieracioides Griseb. & rompezaraguey \\
\hline Vernonia sp. & - \\
\hline Viburnum villosum Sw. & - \\
\hline Vitis tiliaefolia H. \& B. & uva cimarrona \\
\hline Wallenia laurifolia Sw. & casmagua \\
\hline Waltheria indica $\mathrm{L}$. & malva blanca \\
\hline Weinmannia pinnata $\mathrm{L}$. & oreganillo \\
\hline Wissadula amplissima (L.) R.E. Fries. & - \\
\hline Wissadula periplocifolia (L.) Presl. & - \\
\hline Zamia angustifolia Jacq. & guáyara \\
\hline Zanthoxylum cubense P. Wils. & ayúa de sierra \\
\hline Zanthoxylum elephantiasis Macfd. & bayúa \\
\hline Zanthoxylum fagara (L.) Sargent. & amoroso \\
\hline Zanthoxylum martinicense (Lam.) DC. & ayúa \\
\hline Zapoteca gracilis (Griseb.) Bässler & - \\
\hline Zeugites americana Willd. & - \\
\hline Zuelania guidonia (Sw.) Britt. \& Millsp. & guaguasí \\
\hline
\end{tabular}

